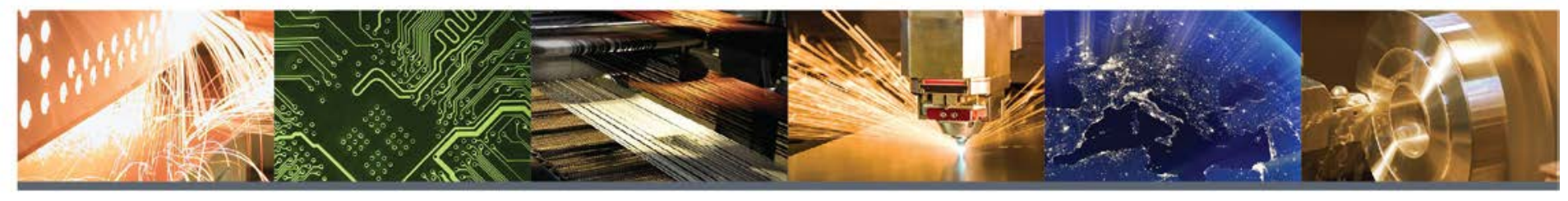

\title{
Global Value Chain and Manufacturing Analysis on Geothermal Power Plant Turbines
}

Sertaç Akar, Chad Augustine, Parthiv Kurup, and Margaret Mann

National Renewable Energy Laboratory

CEMAC is operated by the Joint Institute for Strategic Energy Analysis for the U.S. Department of Energy's Office of Energy Efficiency and Renewable Energy.

Technical Report

NREL/TP-6A20-71128

September 2018 


\section{Global Value Chain and}

\section{Manufacturing Analysis in Geothermal Power Plant Turbines}

Sertaç Akar, Chad Augustine, Parthiv Kurup, and Margaret Mann

National Renewable Energy Laboratory

CEMAC is operated by the Joint Institute for Strategic Energy Analysis for the U.S. Department of Energy's Office of Energy Efficiency and Renewable Energy.

Clean Energy Manufacturing Analysis Center 15013 Denver West Parkway Golden, CO 80401 303-275-3000

www.manufacturingcleanenergy.org
Technical Report

NREL/TP-6A20-71128

September 2018

Contract No. DE-AC36-08G028308 


\section{NOTICE}

This work was authored by the National Renewable Energy Laboratory, operated by Alliance for Sustainable Energy, LLC, for the U.S. Department of Energy (DOE) under Contract No. DE-AC3608G028308. Funding provided by the U.S. Department of Energy Office of Energy Efficiency and Renewable Energy Geothermal Technologies Office. The views expressed herein do not necessarily represent the views of the DOE or the U.S. Government.

This report is available at no cost from the National

Renewable Energy Laboratory (NREL) at

www.nrel.gov/publications.

U.S. Department of Energy (DOE) reports produced after 1991 and a growing number of pre-1991

documents are available

free via www.OSTI.gov.

Cover Photos: (left to right) iStock 2225189; iStock 16687273; Oak Ridge National Laboratory; iStock 24304597; iStock 26005993; iStock 2069560

NREL prints on paper that contains recycled content. 


\section{Foreword}

The U.S. Department of Energy (DOE) established the Clean Energy Manufacturing Analysis Center (CEMAC) at the National Renewable Energy Laboratory (NREL) to conduct credible, objective, industry-relevant, recurring and consistent analyses of clean energy technologies based on established methodologies and prior successful analyses. These analyses provide insights on supply chain dynamics that can aid decision-makers in creating strategies for innovation in manufacturing. CEMAC analyses include several components that enable development of technology-specific and cross-technology insights affecting manufacturing cost and location decisions (Sandor et al., 2017). The main types of CEMAC analysis include;

- Current and prospective global supply chains and trade flows of materials and components necessary for the manufacture of clean energy technologies,

- Detailed manufacturing costs analysis, including the total costs of products manufactured in the U.S. relative to regions around the world,

- Determination of the main drivers of costs and the sensitivity of those drivers to technical and market inputs,

- Qualitative factors and their role in determining the location of new manufacturing facilities such as; intellectual property ownership and protection, opportunities for automation and advanced manufacturing, supporting infrastructure impacts, and trade restrictions.

In this study, we have undertaken a robust analysis of the global supply chain and manufacturing costs for components of Organic Rankine Cycle (ORC) turboexpanders and steam turbines used in geothermal power plants. We collected a range of market data influencing manufacturing from various data sources and determined the main international manufacturers in the industry. We developed a bottom-up manufacturing cost model which includes the raw materials, intermediate products, and final manufactured parts. In addition, we established industry contacts to discuss challenges currently faced by the industry, focusing on both economic factors (e.g. labor availability, energy cost, and capital availability) and noneconomic factors (such as innovation culture, proximity to universities/innovation hubs, government policies, trade security and ease of doing business), that influence manufacturing cost. 


\section{Acknowledgments}

This work was supported by the U.S. Department of Energy, Office of Energy Efficiency and Renewable Energy (EERE), Geothermal Technologies Office (GTO) under Contract No. DE-AC3608-G028308 with the National Renewable Energy Laboratory (NREL). The authors wish to thank reviewers for their comments and suggestions including Doug Arent, Jill Engel-Cox, Emily Newes, Samantha Reese, and Ahmad Mayyas from NREL. The authors also thank Billy Roberts from NREL for his help on mapping. All errors and omissions are the responsibility of the authors. 


\section{Nomenclature or List of Acronyms}

DCF

IRR

NPV

PPA

NCC

IDC

MSP

MAWH

DOE

NREL

CEMAC

SAM

GETEM

GEA

IEA

BNEF

ORC

WHR

CSP

CNC

OSTB

CMM

DFMA $^{\oplus}$

IPSEpro ${ }^{\circ}$

WACC

COGS

SG\&A

$D \& E$

FTE

NCG

ACC

$\mathrm{HX}$
Discounted Cash Flow

Internal Rate of Return

Net Present Value

Power Purchase Agreement

Net Capital Cost

Interest During Construction

Minimum Sustainable Price

Maximum Allowable Working Hours

U.S. Department of Energy

National Renewable Energy Laboratory

Clean Energy Manufacturing Analysis Center

System Adviser Model

Geothermal Electricity Technology Evaluation Model

Geothermal Energy Agency

International Energy Agency

Bloomberg New Energy Finance

Organic Rankine Cycle

Waste Heat Recovery

Concentrated Solar Power

Computer Numerical Model

Over-Speed Testing and Balance

Coordinate Measuring Machine

Design for Manufacturing and Assembly

Software for Thermal Process Simulation

Weighted Average Cost Capital

Inflation on Cost of Goods Sold

Selling, General and Admission

Design and Engineering

Full Time Employee

Non-Condensable Gas

Air Cooled Condenser

Heat Exchanger 


\section{Executive Summary}

The global geothermal electricity market has significantly grown over the last decade and is expected to reach a total installed capacity of 18.4 GWe in 2021 (GEA, 2016). When planning geothermal power projects, geothermal project developers currently customize the size of the power plant to fit the resource being developed. The turbine is designed and sized to optimize efficiency and resource utilization for electricity production; most often, other power plant components are then chosen to complement the turbine design. These custom turbine designs demand one-off manufacturing processes, which result in higher manufacturing setup costs, longer lead-times, and higher capital costs overall in comparison to larger-volume line manufacturing processes. In contrast, turbines produced in standard increments and manufactured in larger volumes could result in lower costs per turbine. This study focuses on analysis of the global supply chain and manufacturing costs for Organic Rankine Cycle (ORC) turboexpanders and geothermal steam turbines.

In this study, we developed a manufacturing cost model to identify requirements for equipment, facilities, raw materials, and labor. We analyzed three different cases 1) $1 \mathrm{MWe}$ geothermal ORC turboexpander 2) $5 \mathrm{MWe}$ ORC turboexpander and 3) $20 \mathrm{MWe}$ geothermal steam turbine, and calculated the cost of manufacturing the major components, such as the impellers/blades, shaft/rotor, nozzles, inlet guide lanes, disks, and casings. Then we used discounted cash flow (DCF) analysis to calculate the minimum sustainable price (MSP). The results showed that MSP could highly vary between $893 \$ / \mathrm{kW}$ and $30 \$ / \mathrm{kW}$ based on turbine size, standardization and volume of manufacturing. The analysis also showed that the economy of scale applies both to the size of the turbine and the number manufactured in a single run. As an example, the unit price of a $5 \mathrm{MW}$ standard design turbine could be $150 \$ / \mathrm{W}$ cheaper than the custom design. Sensitivity analysis indicated that these savings come largely from reduced labor costs for design and engineering and manufacturing setup. In addition to manufacturing cost savings, there is a delivery time saving up to 10 months, which could have a positive effect on construction financing operation time. Another advantage of these standard turbines is their adaptability to different geothermal systems by operating at off-design conditions.

Standard turbine designs only make economic sense if the manufacturing cost savings offset potential losses in electricity generation and revenue over a wide range of operating conditions. Off-design turbine efficiencies determine the commercially-favorable operating range of a standard ORC compared to custom-designed ORC equipment. To compare the economics of standard and custom turbine designs, we developed a model of a $5 \mathrm{MW}$ Geothermal Power Plant using a given design point optimized to maximize power generation for a $175^{\circ} \mathrm{C}, 80 \mathrm{~kg} / \mathrm{s}$ geothermal resource by using IPSEpro ${ }^{\circ}$ software. Then, we varied the geothermal resource over a range of temperatures and flow rates and compared power generation of the standard turbine operating at off-design conditions to a custom turbine operating a constant isentropic efficiency. We used these performance calculations and power output results in a DCF analysis, using NREL's System Advisor model (SAM), of plant operations, costs and financing, thereby creating representative techno-economic models of a total geothermal power plant using Geothermal Electricity Technology Evaluation Model (GETEM) and).performed DCF analysis of 
standard and custom design turbines using results from IPSEpro over a range of temperatures of interest; 63 different off-design cases were analyzed. These data helped us to explore the question; "Can today's capital cost savings compensate the future revenue losses due to lower electricity generation?" The results showed that the net capital cost savings from a standard design vs. a custom design turbine at the standard turbine design point for the modeled $5 \mathrm{MW}$ case study may reach up to $\$ 2.3 \mathrm{M}$, while the difference in the NPV a could reach up to $\$ 1.4 \mathrm{M}$. Our conclusion is that the study does not consider factors such as the demand for ORC turbines, the cost of carrying standard turbines as inventory, the optimum size for a standard turbine, etc., the results show that the standard turbines could be competitive over a wide range of temperatures and flow rates cases near their design point. 


\section{Table of Contents}

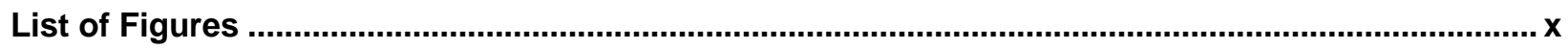

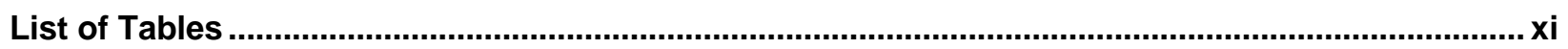

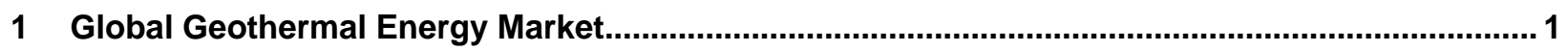

1.1 Historical, current and projected global installations.............................................................. 1

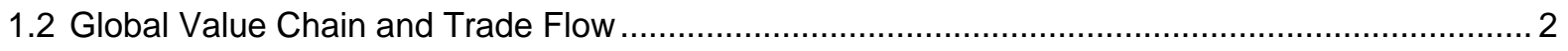

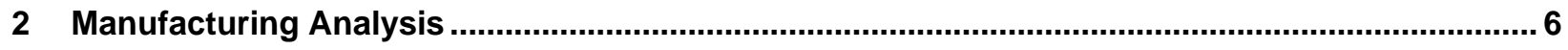

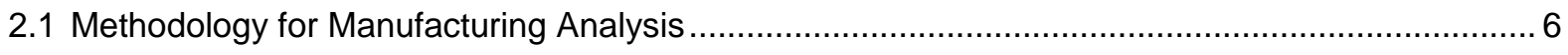

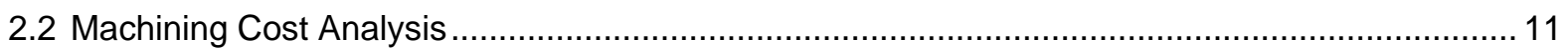

3 Minimum Sustainable Price (MSP) and Discounted Cash Flow (DCF) Analysis ....................... 12

4 Manufacturing Analysis Case Studies ................................................................................... 14

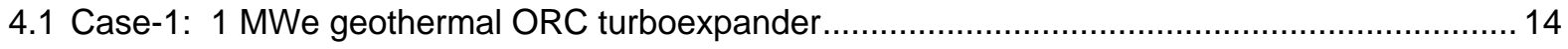

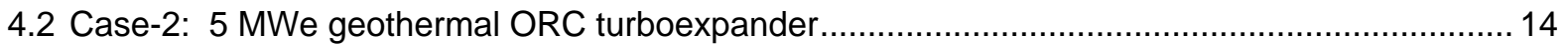

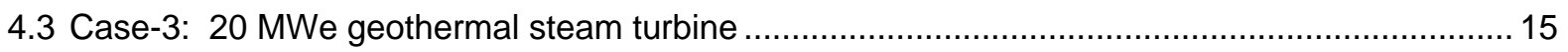

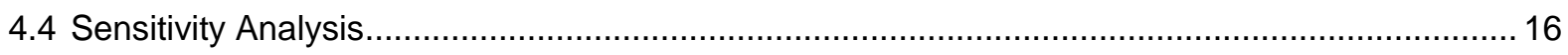

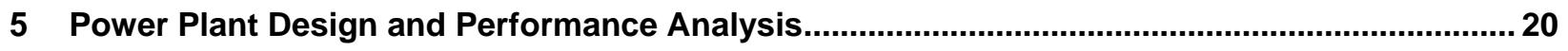

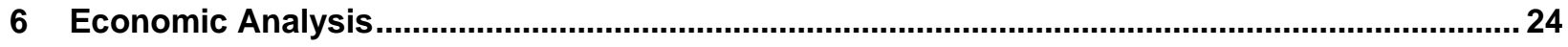

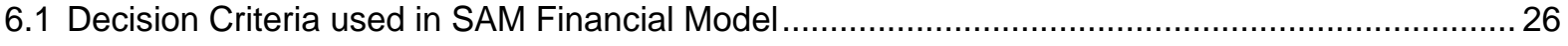

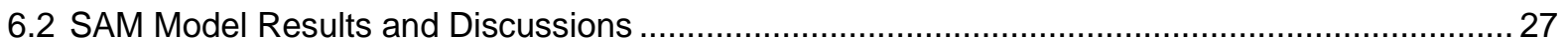

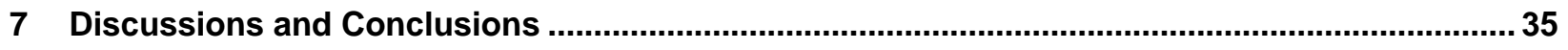

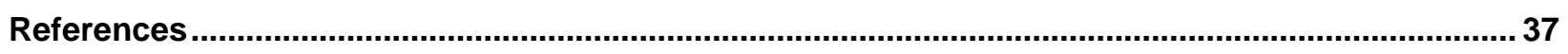

Appendix: List of Global Geothermal Power Plants..................................................................... 39 


\section{List of Figures}

Figure 1 Historical, current, and projected global installations of geothermal power plant turbines. Data displayed represent the median figures which have been compiled from GEA (2016), BNEF (2016), and Bertani (2016). ( $\mathrm{P}=$ projection)

Figure 2 Overview of global ORC turboexpander market between 2005 and 2016 (Data modified from Tartiere (Tartiere 2016); lab-scale prototypes and installed capacity lower than $50 \mathrm{kWe}$ have not been included)

Figure 3 Global trade flow map of geothermal turbines, 2005-2015. Data are from a CEMAC analysis of industry outreach, GEA (2015 and 2016), BNEF (2013, 2014, 2015 and 2016), and Bertani (2016)... 4

Figure 4 Manufacturing process flow diagram for geothermal power plant turbines.....

Figure 5 World Steel Production, *Units are in million metric tons per year. (Data Source: World Steel information system, World Steel Dynamics, 2015).

Figure 6 World Titanium Ore Production, *Units are in thousand metric tons per year. (Data Source: USGS Minerals Year Book, 2015).

Figure 7 Machine inventory for the custom factory model

Figure 8 Representative material and machining cost estimates of a typical impeller for both custom design and standard design (at a volume of 10 units per year) 5 MWe Turboexpander

Figure 9 Calculated MSP and manufacturing cost breakdown for a 1 MWe ORC turboexpander in different volumes of manufacturing in the United States. Data is taken from an ongoing CEMAC cost analysis.

Figure 10 Calculated MSP and manufacturing cost breakdown for a 5 MWe ORC turboexpander in different volumes of manufacturing in the United States. Data is taken from an ongoing CEMAC cost analysis

Figure 11 Calculated MSP and manufacturing cost breakdown for a 20 MWe geothermal steam turbine in different volumes of manufacturing in the United States. Data is taken from an ongoing CEMAC ..... 15

Figure 12 Sensitivity analysis for 5 MWe turboexpander based on A) Manufacturing volume of 1 unit/year (Custom Design) and B) Manufacturing volume of 10 units per year (Standard Design) in the United States (Data is from an ongoing CEMAC cost analysis).

Figure 13 Manufacturing cost drop by cost factor for a standard design (10 units) 5 MWe ORC turboexpander (Data: ongoing CEMAC cost analysis)....

Figure 14 Sensitivity analysis for 20 MWe turboexpander based on A) Manufacturing volume of 1 unit per year (Custom Design) and B) Manufacturing volume of 5 units per year (Standard Design) in the United States (Data is from an ongoing CEMAC cost analysis).

Figure 15 Manufacturing cost drop by cost factor for a standard design (5 units) 20 MWe steam turbine (Data: ongoing CEMAC cost analysis)

Figure 16 Process Flow Diagram of Standard Size ORC Power Plant 21 
Figure 22 NPV difference between custom and standard design scenarios for given resource conditions. Green colored areas with positive values represent cases where standard design turbines are favorable. Black solid line represents the economic boundary of standard turbines where NPV difference is zero.

Figure 23 Standard turbine design gross turbine output in $\mathrm{kW}$ as a function of geothermal brine temperature and flow rate. Standard turbine design output (nameplate capacity) is 5,000 kW.

Figure 24. Sensitivity analysis for NPV difference with respect to relative isentropic efficiencies for select cases .

Figure 25 Sensitivity analysis for NPV difference with respect to relative isentropic efficiencies for all cases (Green, yellow and red dashed lines represent the lower limit, median and upper limit respectively.).

Figure 26 The required isentropic efficiency of the standard turbine relative to a custom turbine to get a break-even NPV.

Figure 27 Plant cost savings (standard minus custom) as a function of geothermal brine temperature and flow rate

\section{List of Tables}

Table 1 Inconel Alloy Element Compositions by Weight …............................................................. 9

Table 2 Number of required machines for different volumes of manufacturing at MAWH ...................... 10

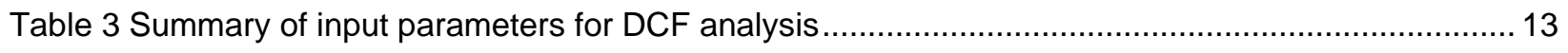

Table 4 Comparison of MSPs for standard and custom design turbines ............................................ 19

Table 5 Base Case Geothermal Resource Characterization for SAM financial Model............................. 24

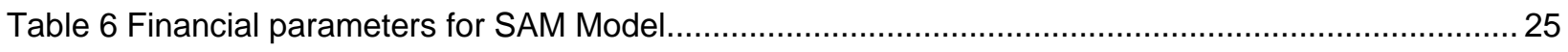

Table 7 Summary of financial parameters used to calculate financial outputs..................................... 27

Table 8 Comparison of SAM financial model results for custom and standard design scenarios ............. 27 


\section{Global Geothermal Energy Market}

The global geothermal market has significantly grown over the last decade with approximately 4.75 GW of new capacity, contributing to overall geothermal power capacity of 13.65 GW (GEA, 2016; TGE Research, 2017; Enerji Atlasi, 2018). In the 10 years ending in December 2015, 118 binary cycle, 58 flash cycle, and 14 dry steam geothermal power plants were installed around the world, including (in order of installed capacity) the United States, New Zealand, Turkey, Indonesia, Kenya, Iceland, Italy, Mexico, Nicaragua, Philippines, Germany, El Salvador, Papua New Guinea, Costa Rica, Guatemala, Japan, Portugal, China, Russia, France, Australia, and Romania (Bertani, 2016). Flash cycle plants accounted for the greatest share of the new capacity (49.5\%), and the greatest quantity of installations was binary cycle. The capacity share of binary cycle and dry steam turbines was $38.7 \%$ and $11.8 \%$ respectively (Bertani, 2016).

\subsection{Historical, current and projected global installations}

Based on pipeline projects (BNEF, 2016), and forecasts (GEA, 2016), the number of geothermal electricity projects are expected to grow and reach about $18.4 \mathrm{GW}$ by 2021 (Figure 1), which could then create demand for a diverse mix of geothermal turbine types. It is unclear currently whether the additional expected capacity increases and the demand are sufficient to allow for standard turbines and turboexpanders to be created, rather than the customized turbines today that can be optimized for the resource conditions. However, Given the information about proposed projects and resource assessments, there is potential value in creating standard turbine sizes that could be adapted to the diversity of projects to offer an economic advantage. This study evaluates the economics of possible standard geothermal turbine sizes and the associated manufacturing costs in the United States.

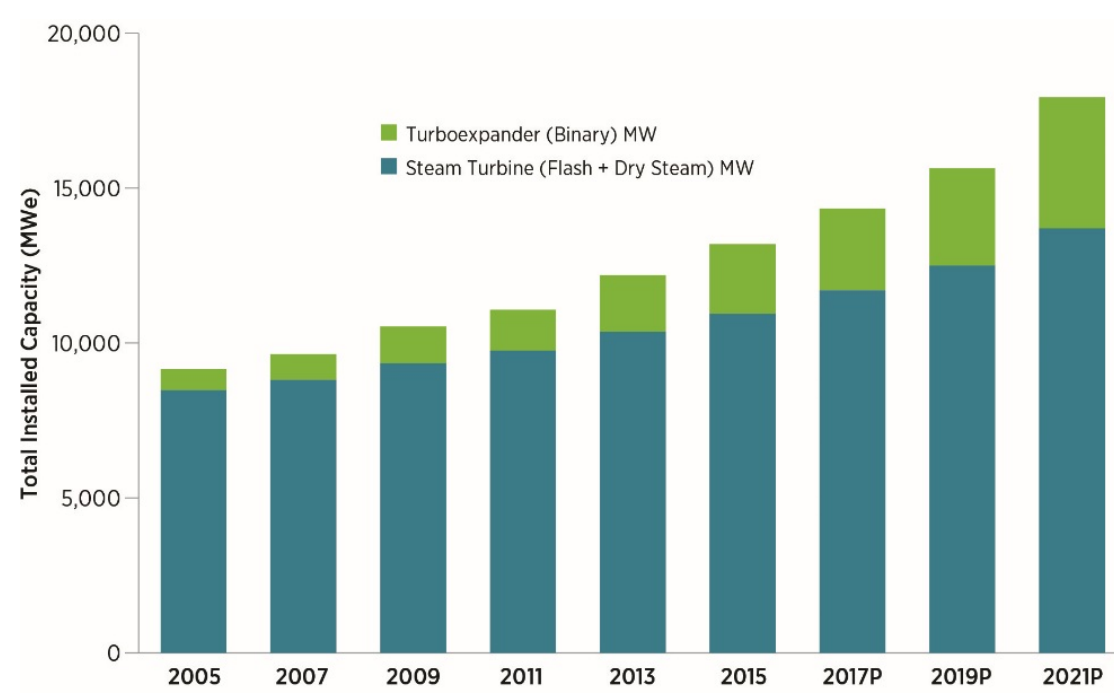

Figure 1 Historical, current, and projected global installations of geothermal power plant turbines. Data displayed represent the median figures which have been compiled from GEA (2016), BNEF (2016), and Bertani (2016). ( $P$ = projection) 


\subsubsection{Organic Rankine Cycle Turbines}

Binary cycle geothermal plants mostly utilize ORC turboexpanders. Apart from geothermal energy applications, the ORC technology has also been used for other commercial applications - such as waste heat recovery (WHR), bioenergy production (from biogas and landfill gas), and concentrating solar power (CSP)-over the last decade. While bioenergy has the greatest number of ORCs installed (for waste heat recovery with smaller installed sizes), geothermal power plants contributed to $71 \%$ of all ORC installed capacity in the world between 2005 and 2016 (Figure 2), bioenergy and WHR follow with 15\% and 13.7\%, respectively (Tartiere, 2016).
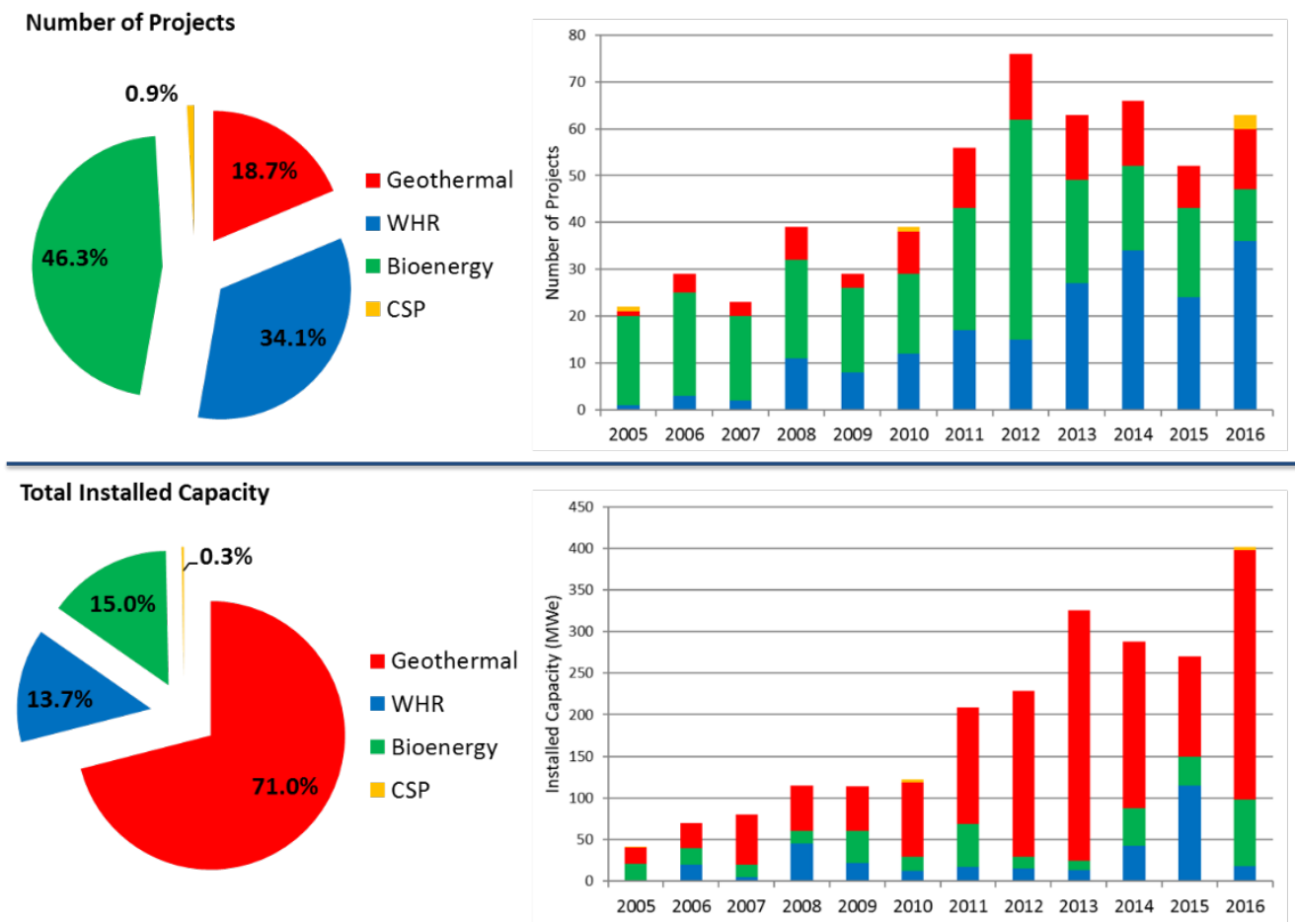

Figure 2 Overview of global ORC turboexpander market between 2005 and 2016 (Data modified from Tartiere (Tartiere 2016); lab-scale prototypes and installed capacity lower than $50 \mathrm{kWe}$ have not been included)

\subsection{Global Value Chain and Trade Flow}

Geothermal project developers customize the size of the power plant to fit the resource being developed. The steam turbine in particular is designed and sized to optimize efficiency and resource utilization for electricity production; most often, other power plant components are then chosen to complement the turbine design. For example, in the Imperial Valley, Southern California, the Salton Sea Unit 5 geothermal steam turbine is designed and optimized for 58.32 MWe (Fuji Electric, 2012). These custom turbine designs demand one-off manufacturing processes, which result in higher manufacturing setup costs, longer lead times, and higher capital costs overall than larger-volume line manufacturing processes. In contrast, turbines produced in standard capacity increments are manufactured in larger volumes for the fossilbased power industry, which results in lower costs per turbine. 
Based on interviews with industry experts, the current manufacturing process for geothermal turbines is made-to-order; the challenges of geothermal reservoir chemistry force designs to use specialty metals that cost more than those used in fossil fuel-powered turbines; additionally, the large fixed costs of resource development and low geothermal energy sales prices lead developers to customize their turbine sizes to maximize resource utilization. In the case of turboexpanders, these factors result in greater manufacturing set-up costs, more extensive engineering and design, and up to 18 months lead time from initial design to installation. In turn, these factors may impact developers' returns and decrease the attractiveness of deploying geothermal energy.

The steam turbine market is driven by large coal-fired, natural gas-fired, and nuclear power plants. The global steam turbine market is expected to increase from \$14.5 billion in 2013 to $\$ 17.4$ billion by 2020 , with an annual growth rate of $2.6 \%$ over this period (Frost and Sullivan, 2014). Annual global orders for steam turbines are broadly stable at around $100 \mathrm{GW}$, and geothermal steam turbines constitute only $1 \%-2 \%$ of the total annual demand (Frost and Sullivan, 2014).

In this study, we evaluated two major geothermal turbine technologies: binary cycle turboexpanders and flash cycle steam turbines. The analysis included manufacturing location decisions, manufacturing processes, and global regional costs, with a focus on potential economies of scale of both turbine technologies using different annual production rates and standardized unit design.

A handful of international manufacturers dominate the global geothermal turbine market. The main manufacturing locations for binary cycle turboexpanders are Israel, the United States, Italy, and Germany. The flash cycle geothermal steam turbine manufacturing countries are Japan, Italy, the United States, France, Mexico, Russia, India, and China. Japan accounts for $82 \%$ of the geothermal steam turbine manufacturing market while Israel accounts for $74 \%$ of the geothermal binary cycle turboexpander manufacturing market. Italian turboexpander manufacturers have started to increase their share in the geothermal market with significant growth in the last couple of years. The United States also plays an important role both as exporter and importer in the global trade flow of geothermal turbines (Figure 3). A full list of installed geothermal power plants between 1958 and 2015 can be found in Appendix.

A comprehensive study of the U.S. geothermal market by NREL suggests that approximately $784 \mathrm{MWe}$ is expected to come online by 2020, and an additional 856 MWe could come online in the next 5 years if existing barriers could be removed to expedite project development (Wall and Young, 2016).

Indonesia is not only second worldwide in installed geothermal capacity; it also far exceeds all other countries in estimated geothermal potential and has a rapidly growing demand for electricity. Indonesia's current installed geothermal power capacity is 1,868 MWe, and the government has ambitious plans for geothermal development of 6,500 MWe by 2025 (Poernomo et al, 2015). Indonesia has a high feed-in-tariff (FIT) policy which ranges from 12.6 to $26.2 \mathrm{c} / \mathrm{kWh}$ (Poernomo et al, 2015). 


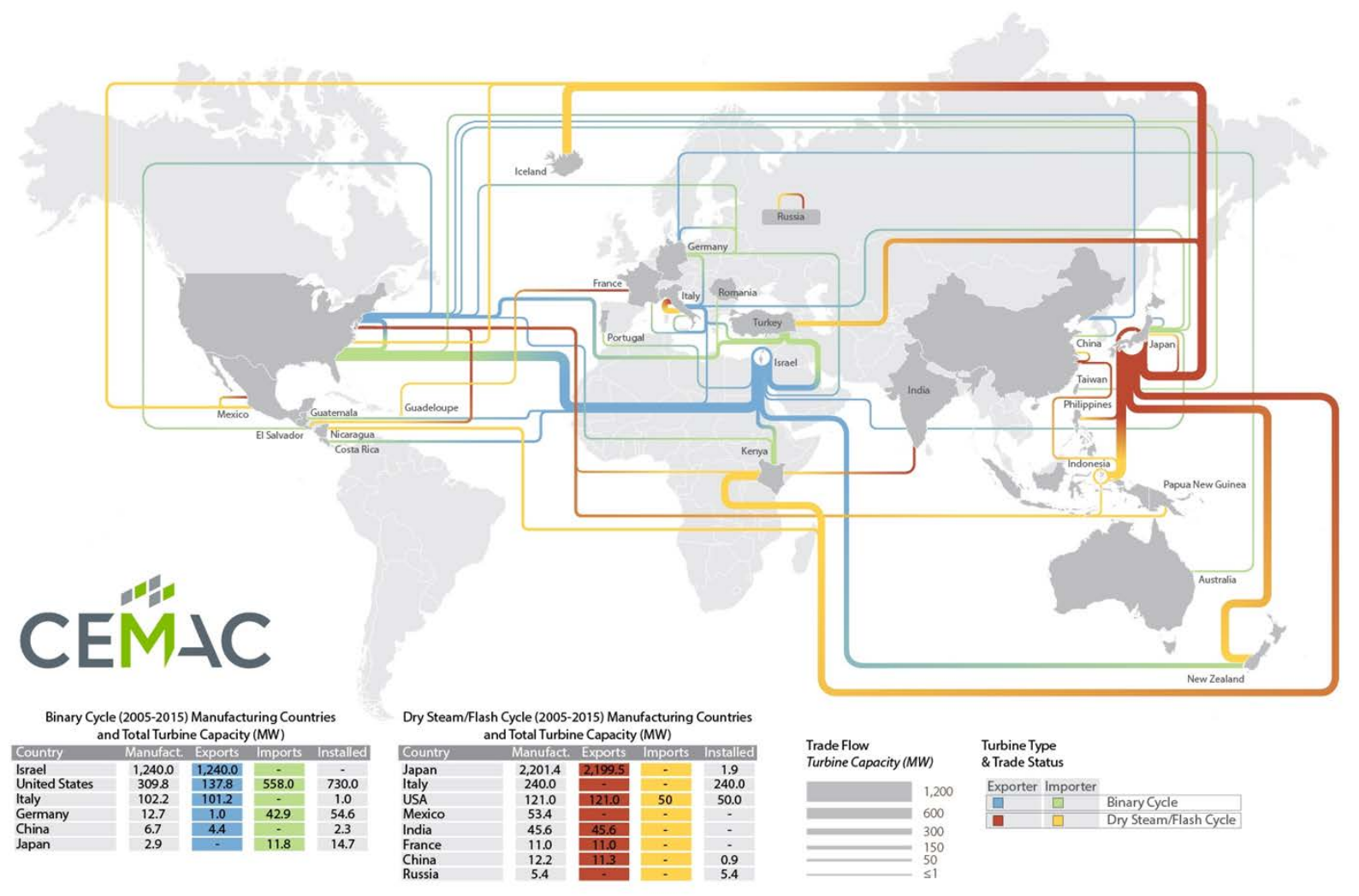

Figure 3 Global trade flow map of geothermal turbines, 2005-2015. Data are from a CEMAC analysis of industry outreach, GEA (2015 and 2016), BNEF (2013, 2014, 2015 and 2016), and Bertani (2016).

Turkey has 1,129 MW of installed capacity as of March 2018 and a capacity target of 1,900 MWe including the projects in the pipeline (Enerji Atlasi, 2018). Turkey implemented a renewable energy law in 2010 to reach its target for increasing the share of renewables up to $30 \%$ of the energy mix by 2023 (IEA, 2011). The Turkish FIT for geothermal power plants is 10.5 $\mathrm{c} / \mathrm{kWh}$. The FIT applies for 10 years of power generation and producers also benefit from an $85 \%$ discount on transmission costs for the 10 years. The 2010 Renewable Energy Law also includes bonus payments for hardware components made in Turkey to support and boost the national manufacturing sector. Companies who rely on locally produced equipment/components receive a bonus FIT, fixed at $1.3 \mathrm{c} / \mathrm{kWh}$ for turbines, $0.7 \mathrm{c} / \mathrm{kWh}$ for generators, $0.7 \mathrm{c} / \mathrm{kWh}$ for pumps and compressors (IEA, 2011). This has increased developers' and manufacturers' interest in domestic manufacturing. The total FIT for geothermal could reach up to $13.2 \mathrm{c} / \mathrm{kWh}$ with 10 years of purchasing guarantee. 
Kenya reached 681 MWe of installed capacity in 2016 by adding 45 MWe of extra capacity from refurbishment of the existing Olkaria power plant units (GEA, 2016). Kenya is currently under a very aggressive phase of development with an aggressive construction pipeline of new projects in several geothermal resource areas. An additional $680 \mathrm{MWe}$ of capacity is expected to come online by 2018 . Total estimated resource potential of the country is around $10 \mathrm{GW}$ (GEA, 2016). 


\section{Manufacturing Analysis}

For this study, we developed a bottom up manufacturing cost model that considers the materials, manufacturing steps and equipment, and assembly of turbine subcomponents. First, we collected data from literature and informative interviews with industry regarding actual manufacturing operations. Existing published cost analyses and previous models of current manufacturing practices developed by CEMAC were also used. Next, we developed a process flow diagram to identify the raw materials, required manufacturing processes and equipment, and utility requirements that are inputs to the cost model (Figure 4). Raw materials required for pre-processing are iron ore, carbon, chromium, molybdenum, nickel, titanium, and aluminum. The most common processed materials used are stainless steel, Inconel (nickel) alloys, and titanium alloys (Ellis and Conover, 1981; Kaya and Hoshan, 2005). Additionally, epoxy-based refined plastics are used for insulation and sealing purposes.

\subsection{Methodology for Manufacturing Analysis}

\subsubsection{Manufacturing process flow}

The manufacturing cost model includes three main steps 1) Materials (raw and processed), 2) Manufacturing (in-house machining and outsourced parts) and 3) final assembly. The final product could be either an ORC Turboexpander or a geothermal steam turbine.
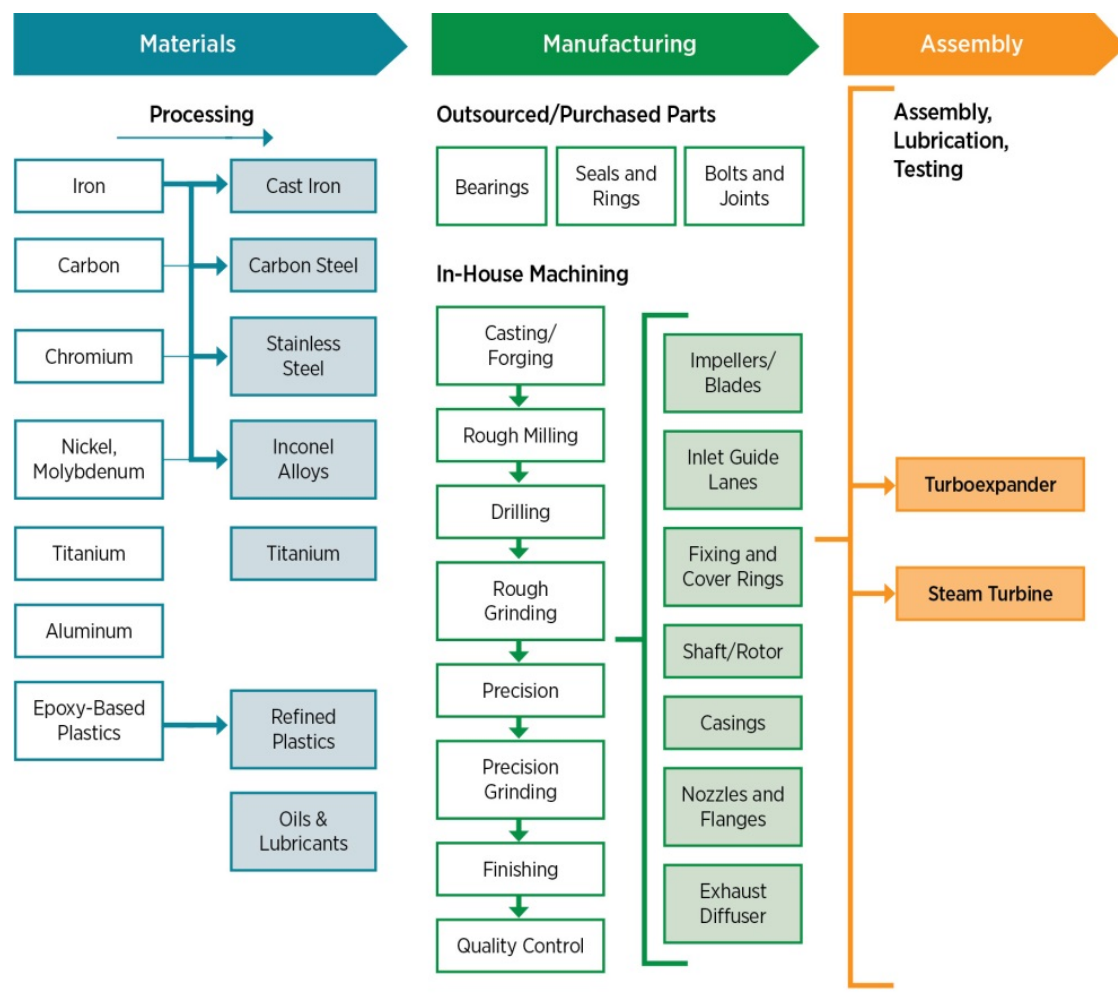

Figure 4 Manufacturing process flow diagram for geothermal power plant turbines 


\subsubsection{Materials}

The most common corrosion resistant materials used for machining the impellers are titanium or stainless steel; the shaft is produced from stronger material such as forged nickel alloy or Inconel. Geothermal fluids contain dissolved $\mathrm{CO}_{2}, \mathrm{H}_{2} \mathrm{~S}, \mathrm{NH}_{3}$ and chloride ions that can cause corrosion of metallic materials. The main corrosion problems are pit corrosion, cracking corrosion, breaking with stressed corrosion, breaking with sulphur stressed corrosion, corrosion between the particles and wearing corrosion (Kaya and Hoshan, 2005).

Stainless steel material decreases the probability of uniform corrosion formation in geothermal fluid environment. AISI 400 series stainless steels contain $12-18 \%$ chrome, which is more suitable for turbine blades. AISI 430 (Ferrite) and AISI 431 (Martensitic) stainless steels are often used for valve and pump components in geothermal systems. Stainless steel production is wide spread throughout the world (Figure 5). Based on world steel dynamics 2015 data, China, Japan, and the United States are the top three countries in stainless steel production.
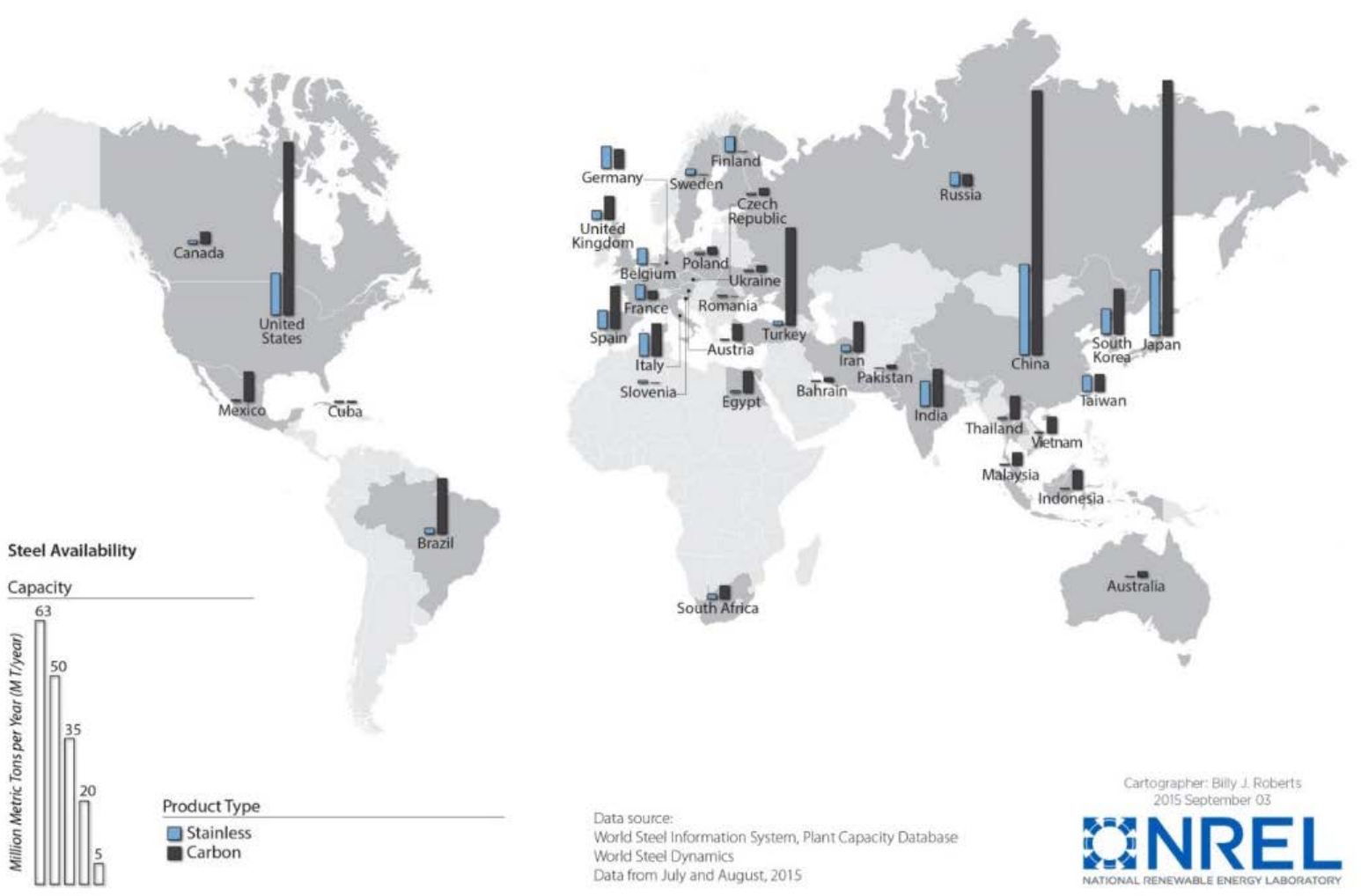

Figure 5 World Steel Production, *Units are in million metric tons per year. (Data Source: World Steel information system, World Steel Dynamics, 2015)

Titanium and titanium alloys are more resistant to corrosion. In addition, titanium is resistant to cavitation and impact damages. Titanium alloys are much more resistant to local corrosion than pure titanium. Ti-code-7 (Ti-0.15 Pd), Ti code-12 (Ti-0.3 Mo-0.8 Ni), and Ti-code-29 (Ti-6 Al-4 V$0.1 \mathrm{Ru}$ ) show well resistance. When they are compared on the basis of cost and performance, 
titanium alloys can be used properly as other stainless steel alloys. The critical places for the use of titanium alloys as the material can be; impellers, wellhead valves, pressure gauges, pipes and blow-out preventers.

The world's titanium production is limited to certain regions (Figure 6). Based on USGS Minerals Year Book 2015 data, Canada, Australia, China, South Africa, Vietnam, the United States, Brazil, India, Mozambique, Madagascar, Norway, Ukraine, Kenya, Kazakhstan, Indonesia, Malaysia and Siri Lanka are the main countries for titanium production.

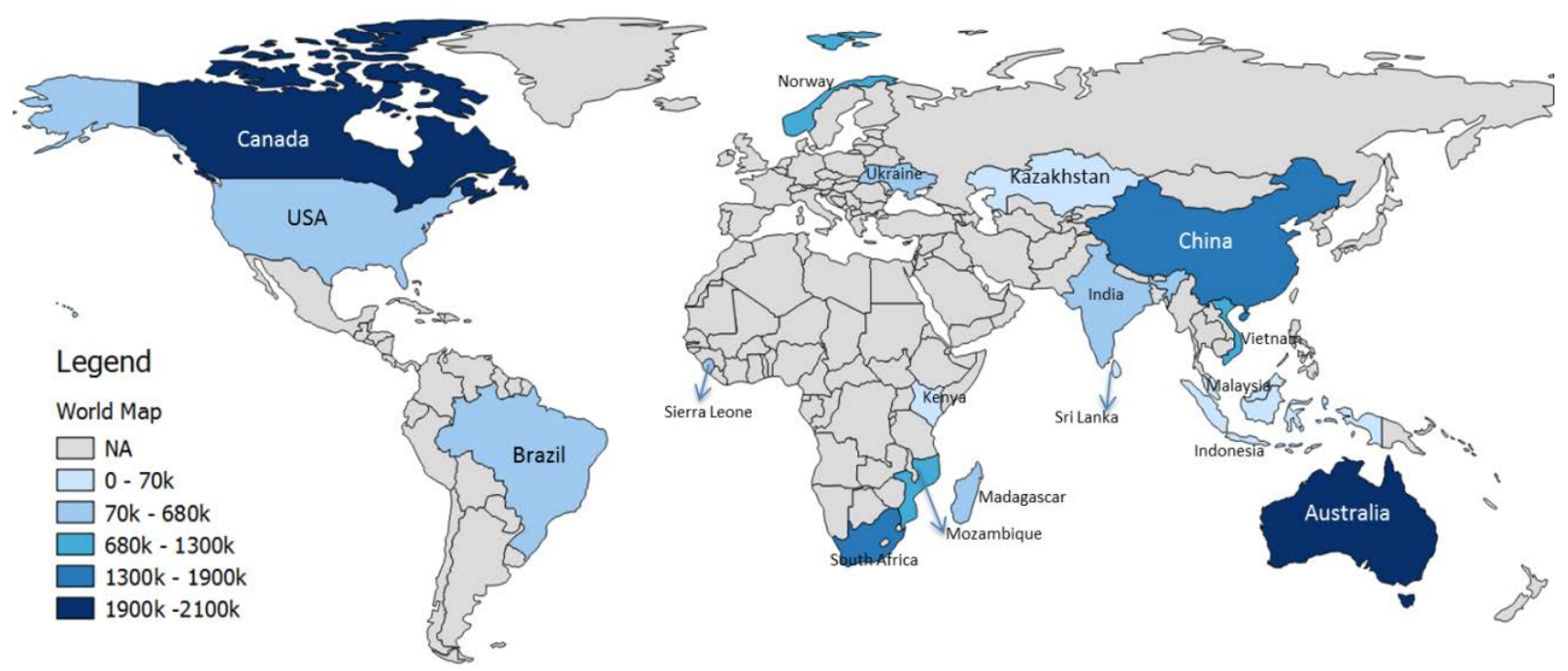

Figure 6 World Titanium Ore Production, *Units are in thousand metric tons per year. (Data Source:

USGS Minerals Year Book, 2015)

Other important material for turbine manufacturing is the Inconel (nickel alloys). There are various types of Inconel available in the market, and the mineral content defines the strength and the corrosion resistance (Table 1). For the high temperature geothermal fluids, it is suitable to use nickel, chromium, and molybdenum ( $\mathrm{Ni}-\mathrm{Cr}-\mathrm{Mo}$ ) alloys as a material (Kaya and Hoshan, 2005). Inconel-625 and Hastelloy C-256 are especially strong in combatting corrosion. Other nickel alloys, which have iron elements, can also be used in some applications. These alloys are much stronger than the stainless steel. Forged Inconel is mostly used for turbine shafts because of its strength against rotational force. 
Table 1 Inconel Alloy Element Compositions by Weight

\begin{tabular}{llllllllllll}
\hline $\begin{array}{l}\text { Inconel } \\
\text { Alloys }\end{array}$ & \multicolumn{2}{l}{ Elements \% by Mass } & & & & & & & & & \\
& $\mathrm{Ni}$ & $\mathrm{Cr}$ & $\mathrm{Fe}$ & $\mathrm{Mo}$ & $\mathrm{Nb}$ & $\mathrm{Co}$ & $\mathrm{Mn}$ & $\mathrm{Cu}$ & $\mathrm{Al}$ & $\mathrm{Ti}$ & Others \\
$\mathbf{6 0 0}$ & 72 & 16 & 10 & 0 & 0 & 0 & 1 & 0.5 & 0 & 0 & 0.5 \\
$\mathbf{6 1 7}$ & 44 & 24 & 3 & 10 & 0 & 15 & 0.5 & 0.5 & 1 & 0.5 & 0.5 \\
$\mathbf{6 2 5}$ & 58 & 20 & 5 & 10 & 4 & 1 & 0.5 & 0 & 0.4 & 0.4 & 0.7 \\
$\mathbf{6 9 0}$ & 60 & 30 & 9 & 0 & 0 & 0 & 0.35 & 0.01 & 0.02 & 0 & 0.62 \\
$\mathbf{7 1 8}$ & 55 & 21 & 12 & 3 & 5 & 1 & 0.3 & 1 & 1 & 0.2 & 0.5 \\
$\mathbf{X - 7 5 0}$ & 70 & 14 & 9 & 0 & 1 & 1 & 1 & 0.5 & 0.5 & 2.5 & 0.5 \\
\hline
\end{tabular}

\subsubsection{Machine inventory and factory model}

Manufacturing processes for subcomponents include casting, forging, and machining. For casting and forging, an electric arc furnace and forging press are required. The manufacturing cost model that we developed includes the minimum factory space required for the machines in addition to machine-related labor requirements. We created an inventory of machinery for heavy machining and precise computer numeric control (CNC) machining processes (Klocke et al., 2014) in addition to quality control and assembly stages (Figure 7). Heavy machining includes electric arc furnace casting and forging operations. CNC machining includes a 5-axis CNC machine, a 3-axis CNC machine, a CNC horizontal lathe, and a CNC grinding machine. Quality control equipment includes a coordinate measuring machine (CMM) in addition to overspeed testing and dynamic balancing (OSTB).

We estimated a minimum machining rate for each machine based on annual maximum allowable working hours (MAWH) and operation hours with and without setup time for the factory model. MAWH is set at 3,400 hours based on 250 annual labor days, 8 working hours with 2 shifts per day, and $85 \%$ production-up-times.

Based on industry standard practices, these machines are as fully utilized as possible across several different projects. For this cost analysis, the capital cost share associated with facilities, space, and machine depreciation for the time when the machine is used on manufacturing the turbine parts is proportional to the use time. This splits capital costs for the equipment between turbine components and other projects that the manufacturer is involved in. In other words, we are only taking the capital cost share associated with facilities, space, and machine depreciation for the time when the machine is used on manufacturing the turbine parts, not the full 3,400 hours per year.

The amount of required machinery was selected based on total operational hours for different volumes of manufacturing and MAWH. If one of each machine type (e.g. one 5-axis CNC, one 3axis $\mathrm{CNC}$ machine and so on) were chosen for all types, there would be enough manufacturing capacity to produce up to a volume of 100 units per year. For greater than 100 units per year, additional machines would be required (Table 2). We selected a manufacturing volume of 50 units/year as a threshold for our analysis, based on manufacturers' annual manufacturing capacities and project portfolio. Annual straight-line depreciation was selected for capital costs 
associated with machinery, as handled in accounting procedures. Facility cost is defined based on minimum required working area for each machine. Energy cost is calculated based on average power consumption of each machine, operating for a given number of operational hours. Storage and shipping costs of the turbine parts/components are not included in the factory model.

\begin{tabular}{|c|c|c|c|}
\hline \multicolumn{2}{|c|}{ Precise CNC Machining } & \multicolumn{2}{|c|}{ Heavy Machining } \\
\hline $\begin{array}{l}5 \text { Axis CNC Machine } \\
\text { Price: } \$ 150,000-\$ 300,000 \\
\text { Footprint: } 10-15 \mathrm{~m}^{2} \\
\text { Energy Consumption: } 20-30 \mathrm{~kW}\end{array}$ & & $\begin{array}{l}\text { Casting } \\
\text { Price: } \$ 500,000-\$ 1,000,000 \\
\text { Footprint: } 1000 \mathrm{~m}^{2} \\
\text { Energy Consumption: } 500 \mathrm{~kW}\end{array}$ & \\
\hline $\begin{array}{l}3 \text { Axis CNC Machine } \\
\text { Price: } \$ 100,000-\$ 200,000 \\
\text { Footprint: } 10-15 \mathrm{~m} 2 \\
\text { Energy Consumption: } 20-30 \mathrm{~kW}\end{array}$ & & $\begin{array}{l}\text { Forging } \\
\text { Price: } \$ 400,000-\$ 500,000 \\
\text { Footprint: } 1000 \mathrm{~m}^{2} \\
\text { Energy Consumption: } 500 \mathrm{~kW}\end{array}$ & Rivers \\
\hline \multirow{2}{*}{$\begin{array}{l}\text { Horizontal CNC Lathe } \\
\text { Price: } \$ 60,000-\$ 150,000 \\
\text { Footprint: } 12-18 \mathrm{~m}^{2} \\
\text { Energy Consumption: } 30-40 \mathrm{~kW}\end{array}$} & & \multicolumn{2}{|c|}{ Quality Control \& Assembly } \\
\hline & & $\begin{array}{l}\text { Assembly Line } \\
\text { Price: } \$ 50,000-\$ 300,000 \\
\text { Footprint: } 50-60 \mathrm{~m}^{2} \\
\text { Energy Consumption: } 5-10 \mathrm{~kW}\end{array}$ & \\
\hline \multirow[t]{2}{*}{$\begin{array}{l}\text { CNC Grinding Machine } \\
\text { Price: } \$ 80,000-\$ 150,000 \\
\text { Footprint: } 35-40 \mathrm{~m}^{2} \\
\text { Energy Consumption: } 10-20 \mathrm{~kW}\end{array}$} & & \multicolumn{2}{|c|}{$\begin{array}{l}\text { Over-speed Testing \& Balancing Machine } \\
\text { Price: } \$ 10,000-\$ 20,000 \\
\text { Footprint: } 10 \mathrm{~m}^{2} \\
\text { Energy Consumption: } 5-7 \mathrm{~kW}\end{array}$} \\
\hline & & \multicolumn{2}{|c|}{$\begin{array}{l}\text { CMM Dimension Measuring Machine } \\
\text { Price: } \$ 8,000-\$ 10,000 \\
\text { Footprint: } 10 \mathrm{~m}^{2} \\
\text { Energy Consumption: } 1-3 \mathrm{~kW}\end{array}$} \\
\hline
\end{tabular}

Figure 7 Machine inventory for the custom factory model

Table 2 Number of required machines for different volumes of manufacturing at MAWH

\begin{tabular}{|cccccccc|}
\hline \#Units & $\begin{array}{c}\text { 5 Axis } \\
\text { CNC } \\
\text { Machine }\end{array}$ & $\begin{array}{c}\text { 3Axis } \\
\text { CNC } \\
\text { Machine }\end{array}$ & $\begin{array}{c}\text { CNC } \\
\text { Horizontal } \\
\text { Lathe }\end{array}$ & $\begin{array}{c}\text { CNC } \\
\text { Grinding } \\
\text { Machine }\end{array}$ & CMM & OSTB & $\begin{array}{c}\text { Assembly } \\
\text { Line }\end{array}$ \\
\hline 10 & 1 & 1 & 1 & 1 & 1 & 1 & 1 \\
\hline 25 & 1 & 1 & 1 & 1 & 1 & 1 & 1 \\
\hline 50 & 1 & 1 & 1 & 1 & 1 & 1 & 1 \\
\hline 100 & 1 & 1 & 1 & 1 & 1 & 1 & 1 \\
\hline 150 & 1 & 2 & 1 & 1 & 1 & 1 & 1 \\
\hline 200 & 1 & 2 & 1 & 2 & 1 & 1 & 1 \\
\hline 500 & 2 & 5 & 3 & 4 & 1 & 1 & 2 \\
\hline 1000 & 3 & 9 & 5 & 7 & 1 & 2 & 3 \\
\hline
\end{tabular}




\subsection{Machining Cost Analysis}

Design for Manufacture and Assembly $\left(D \mathrm{DMA}^{\circledR}\right)$ was used for some of the key, high value components such as impellers and shafts for the manufacturing cost analysis of

turboexpanders. DFMA allows the user to produce a detailed projected cost of the component, based on the volume of material needed, the machines and process steps, machine setup time, and tooling if needed. Tooling investment is calculated for processes such as stamping, sand casting, and forging; it also considers tool wear and lifetime. Figure 8 shows the representative material and machining cost estimates of a typical impeller for both custom design and standard design (at a volume of 10 units) 5 MWe Turboexpander.

As can be seen in Figure 8, a custom design impeller could be $\sim \$ 4,000 /$ unit, compared to $\sim \$ 1,000 /$ unit with the standard design. If we assume same yield rate, the standard design impellers can lead a cost savings of between 25-30\% compared to custom design (single unit) due to the setup times for machining the impeller. A similar approach is applied to other subcomponents of a turboexpander: shaft, nozzles, inlet guide lanes, disks and casings to calculate machining costs.

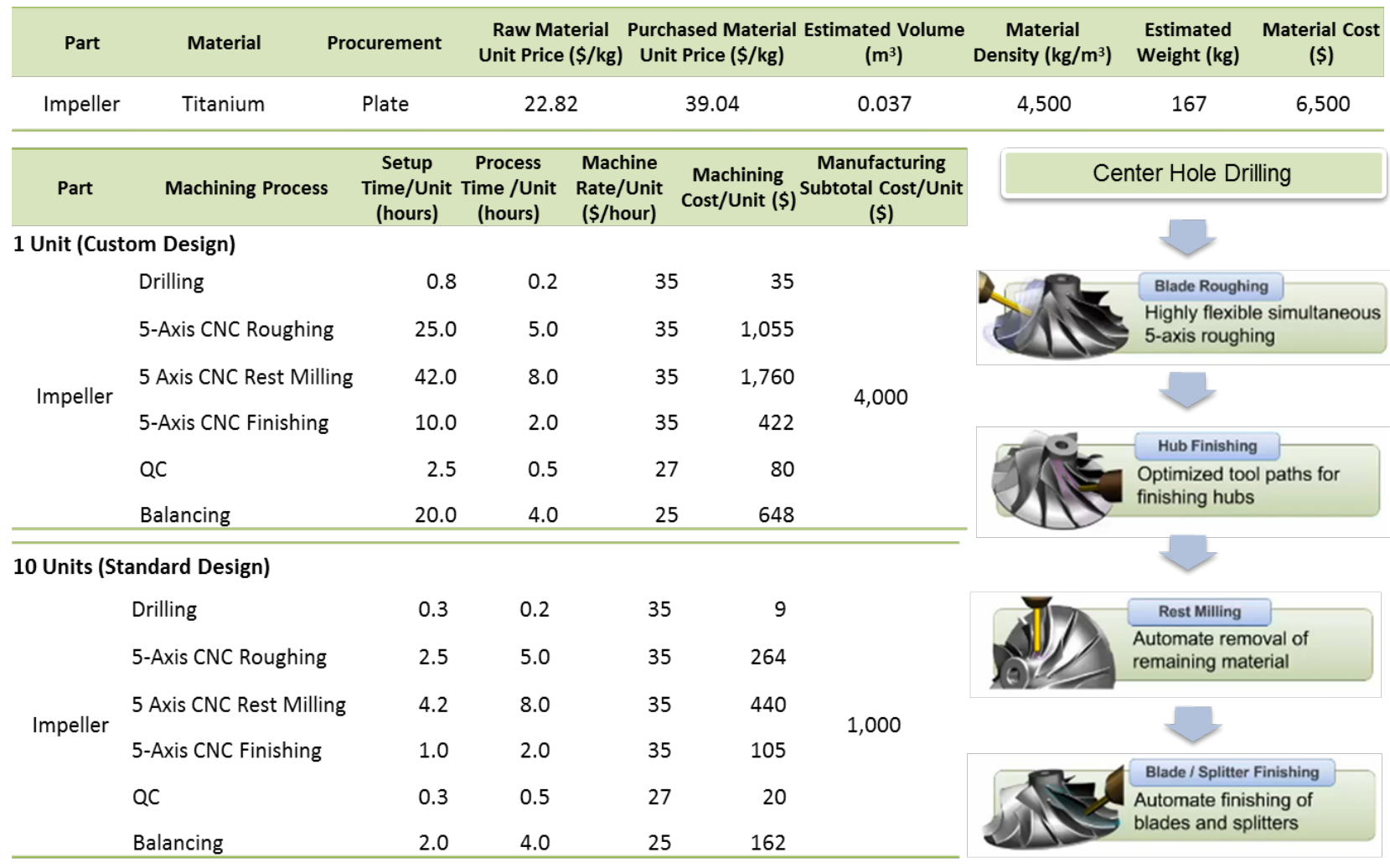

Figure 8 Representative material and machining cost estimates of a typical impeller for both custom design and standard design (at a volume of 10 units per year) 5 MWe Turboexpander 


\section{Minimum Sustainable Price (MSP) and Discounted Cash Flow (DCF) Analysis}

MSP is the minimum price that a company would have to charge for a good or service to cover all variable and fixed costs and make sufficient profit to pay back investors at their minimum required rates of return (Goodrich et al., 2013). The MSP is computed by setting the net present value (NPV) of an investment equal to zero with the internal rate of return equal to the weighted average cost of capital (WACC). We used the U.S. capital assets pricing model to derive these debt and equity ratios, and weight them by their relative contribution to the overall capital structure of the firm to estimate WACC values (Ross et al., 2009).

We also developed a detailed financial model for the DCF of a manufacturing facility. The purpose of the DCF is to provide the necessary framework for deriving the MSP for each product. Within the DCF, we can account for several considerations for manufacturing, such as capital cost, fixed operating costs (labor, depreciation, inflation and taxes, insurance and rent), typical sales, general and administrative (SG\&A) expenses; typical design and engineering (D\&E) cost; and warranty coverage (Goodrich et al., 2013). Table 3 summarizes the input parameters for the DCF analysis.

We calculate the initial equipment and facilities expenditures over straight-line depreciation. The length of the calculation is set by the analysis period, and the discount rate is calculated from the required rates of return; the MSP is then derived by an iterative algorithm that runs until the NPV of the cash flows equals the total initial capital expenditure. 
Table 3 Summary of input parameters for DCF analysis

\begin{tabular}{|lll|}
\hline Inputs for DCF Calculations & Values & Units \\
\hline Inflation on cost of goods sold (COGS) & 3 & $\%$ \\
\hline Corporate interest rate & $\mathbf{3 . 3}$ & $\%$ \\
\hline Initial Loan (or bond) maturity & $\mathbf{1 0}$ & years \\
\hline Corporate tax rate & $\mathbf{3 0}$ & $\%$ \\
\hline Dividend payout rate & $\mathbf{0}$ & $\%$ \\
\hline Cost of equity & $\mathbf{1 0 . 6}$ & years \\
\hline Cash flow analysis period & $\mathbf{2 0}$ & years \\
\hline Working capital collection period & $\mathbf{1 0}$ & $\%$ \\
\hline Calculated WACC & $\mathbf{5 . 3}$ & years \\
\hline Working capital inventory turnover & $\mathbf{4}$ & years \\
\hline Working capital payable period & $\mathbf{1 0}$ & $\%$ \\
\hline CAPEX Initial target capital structure, (\% of debt) & $\mathbf{6 4}$ & $\%$ \\
\hline Replacement equip. target capital structure & $\mathbf{5 0}$ & years \\
\hline Depreciable life for plant & $\mathbf{2 5}$ & years \\
\hline Capital replacement loan maturity & $\mathbf{1 0}$ & N/A \\
\hline Equipment depreciation type & $\mathbf{7}$ Year Straight-line & N/A \\
\hline Tooling depreciation type & $\mathbf{3}$ Year Straight-line & N/A \\
\hline Building depreciation type & $\mathbf{1 5}$ Year Straight-line & \\
\hline
\end{tabular}




\section{Manufacturing Analysis Case Studies}

We analyzed the manufacturing cost and MSP for three different scenarios, where each scenario had 5 volumes of manufacturing: 1) a 1 MWe ORC turboexpander; 2) a 5 MWe ORC turboexpander; and 3) a 20 MWe steam turbine, at manufacturing volumes of 1, 5, 10, 25 and 50. All 3 scenarios assume U.S. production facilities and costs. The generator is considered as a separate piece and is not included in the manufacturing cost analysis. Increasing volumes of manufacturing effectively decreased the manufactured cost per unit, since we spread the capex over more units. Machine setup times and D\&E costs are the cost components that are most impacted by volume manufacturing, as these are essentially one-time charges that are not volume dependent.

\subsection{Case-1: 1 MWe geothermal ORC turboexpander}

In case 1 , the results showed that MSP decreases significantly when we increase the volume of manufacturing from 1 unit (custom design) to 5 units (standard design). The MSP of a single custom design 1 MWe turboexpander was found to be $893 \$ / \mathrm{kW}$ whereas a standard-design 1 MWe turboexpander has an MSP of $226 \$ / \mathrm{kW}$ at a manufacturing volume of 5 (Figure 9).

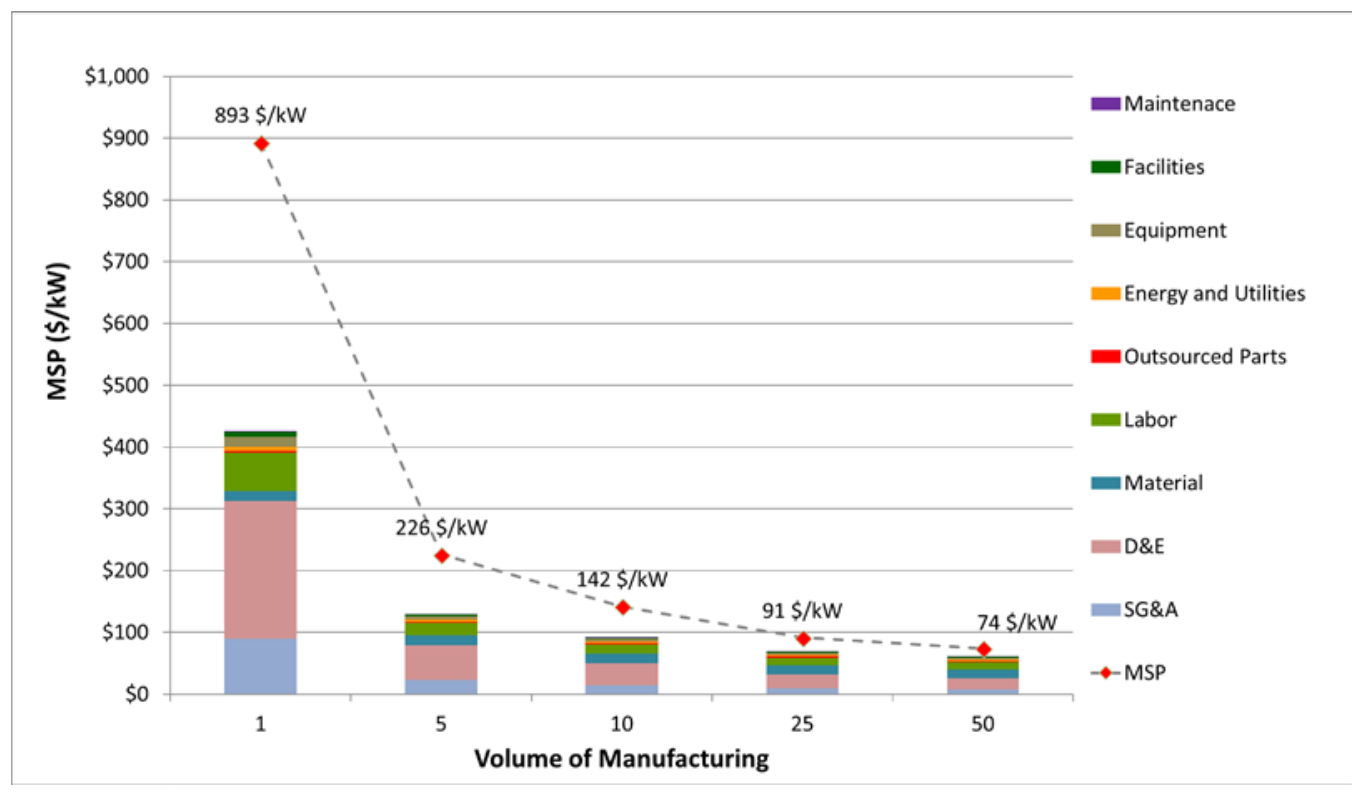

Figure 9 Calculated MSP and manufacturing cost breakdown for a 1 MWe ORC turboexpander in different volumes of manufacturing in the United States. Data is taken from an ongoing CEMAC cost analysis.

\subsection{Case-2: 5 MWe geothermal ORC turboexpander}

In case 2, the results showed that MSP decreases significantly when we increase the volume of manufacturing from 1 unit (custom design) to 5 units (standard design). The MSP of a single custom design 5 MWe turboexpander was found to be $216 \$ / \mathrm{kW}$ whereas a standard-design 1 MWe turboexpander has an MSP of $66 \$ / \mathrm{kW}$ at a manufacturing volume of 5 (Figure 10). 


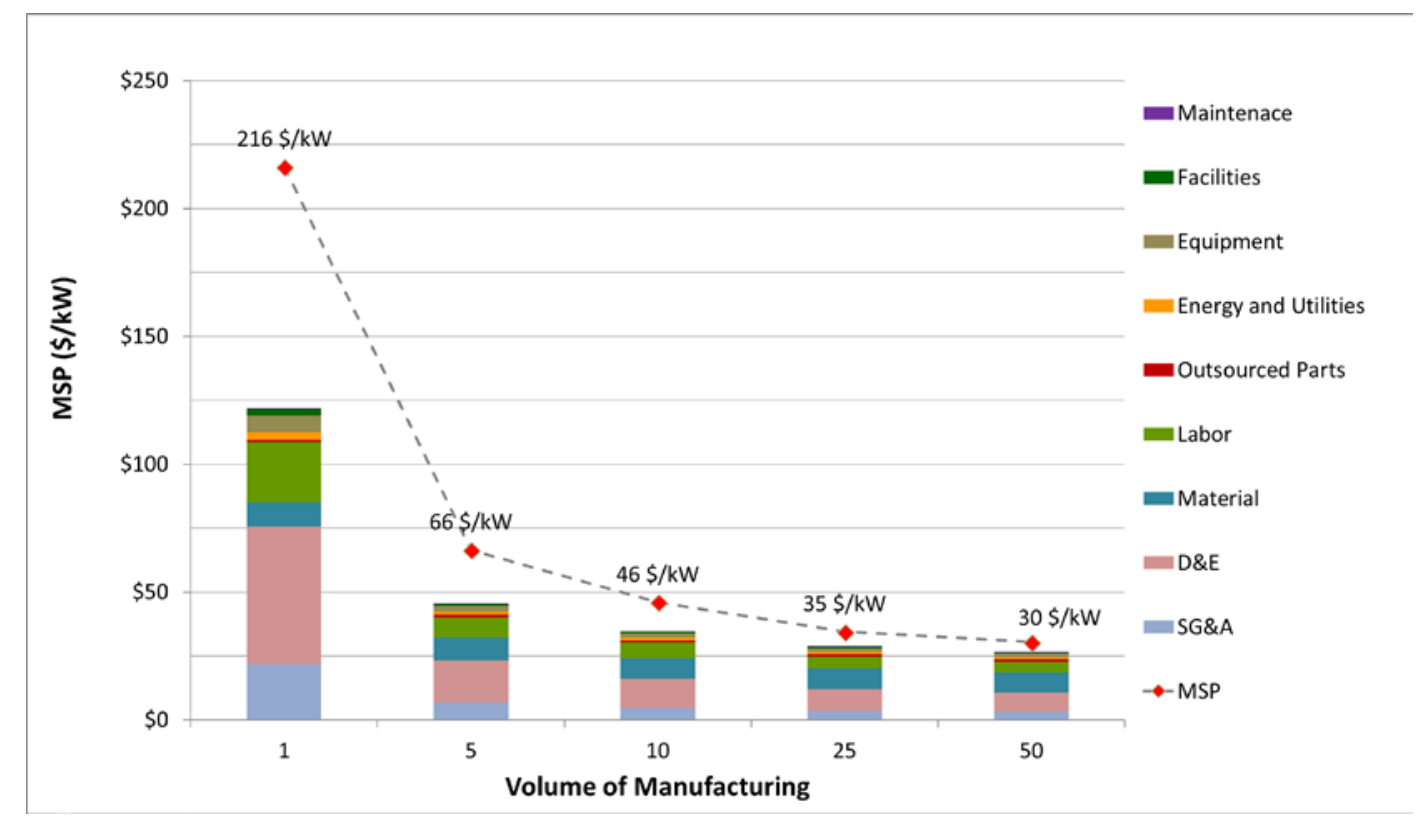

Figure 10 Calculated MSP and manufacturing cost breakdown for a 5 MWe ORC turboexpander in different volumes of manufacturing in the United States. Data is taken from an ongoing CEMAC cost analysis

\subsection{Case-3: 20 MWe geothermal steam turbine}

For scenario 3, we selected a manufacturing volume of up to 5 units per year based on annual demand for geothermal steam turbines and the manufacturing capacities. The MSP of a single custom design $20 \mathrm{MWe}$ geothermal steam turbine is found to be $361 \$ / \mathrm{kW}$, whereas the MSP of a standard-design $20 \mathrm{MWe}$ steam turbine is calculated as $135 \$ / \mathrm{kW}$ at an annual production rate of 5 unit/year (Figure 11).

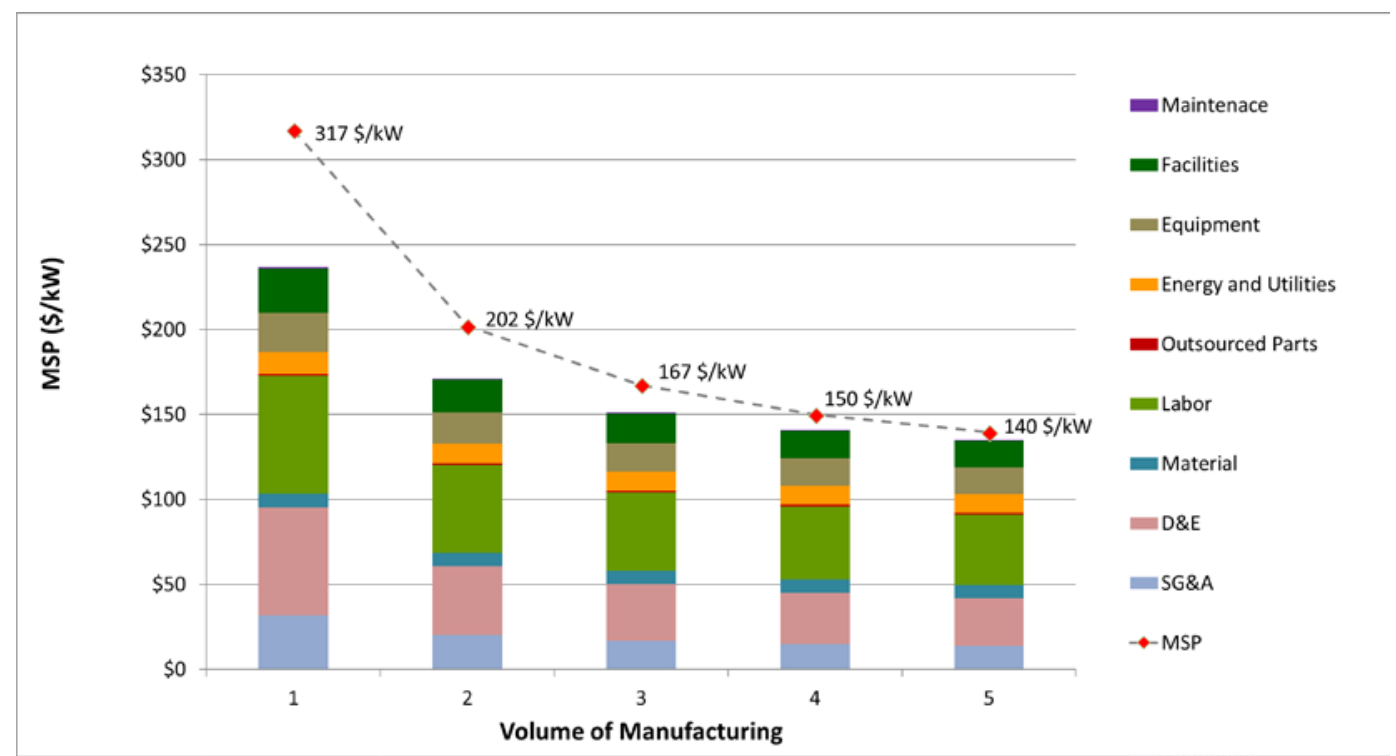

Figure 11 Calculated MSP and manufacturing cost breakdown for a 20 MWe geothermal steam turbine in different volumes of manufacturing in the United States. Data is taken from an ongoing CEMAC 


\subsection{Sensitivity Analysis}

We conducted a sensitivity analysis to determine which cost factors have the greatest impact on the results of the manufacturing cost model. We iteratively varied one input parameter of the cost model while keeping the others constant to determine the impact of each input on the calculated MSP. Each cost factor in the overall cost model has a different weight based on the relative importance, and as such a change in one input variable would have proportional effects relative to the weight on the manufactured cost. For the sensitivity analyses, we evaluated two cases: 1) custom design (1 unit) versus a standard design (10 units per year) for a 5 MWe ORC turboexpander; and 2) custom design (1 unit) versus a standard design (at 5 units per year) for a 20 MWe steam turbine.

The results of the MSP sensitivity analysis for a $5 \mathrm{MWe}$ turboexpander showed that D\&E is the most important cost factor for a custom design unit due to time spent on tailor made design for each custom unit (Figure 12). D\&E is assumed to take 9 months and 2 full time employees (FTE). Manufacturing labor is the second most important factor at a custom design unit due to setup times. Labor includes set up time, which is $51 \%$ of total machining cost for a custom design unit. SG\&A, capital (equipment and facilities), and materials are the other important factors which have a moderate effect on manufacturing cost for a custom design unit. When we assume standard design turboexpanders at volume of 10 units, materials and labor become dominant with shares of $46 \%$ and $31 \%$ respectively, while D\&E and SG\&A costs become less important. The cost drops by cost factor are also presented on cost waterfall charts (Figure 13).

The results of the MSP sensitivity analysis for a $20 \mathrm{MWe}$ steam turbine showed that labor is the most important factor at a custom design unit due to setup times and high labor requirements during assembly (Figure 14). Labor includes set up time, which is $49 \%$ of total machining cost for a custom design single unit. Capital is the second most important cost factor at a custom design. D\&E is assumed to take 12 months and 4 FTEs due to time spent on tailor made parts for each unit. Steam turbines need more detailed design than turboexpanders since they are in direct contact with saturated steam, non-condensable gases (NCG) like $\mathrm{H}_{2} \mathrm{~S}$, and $\mathrm{CO}_{2}$ and have multiple pressure stages. SG\&A, capital (equipment and facilities), and materials are the other important factors that have a moderate effect on manufacturing cost for a custom design unit. When we have one-off-design turbines at a volume of 5 units, while impact factor of labor and material stays almost the same, D\&E and SG\&A cost become less important. The cost drops by cost factor are also presented on cost waterfall charts (Figure 15). 


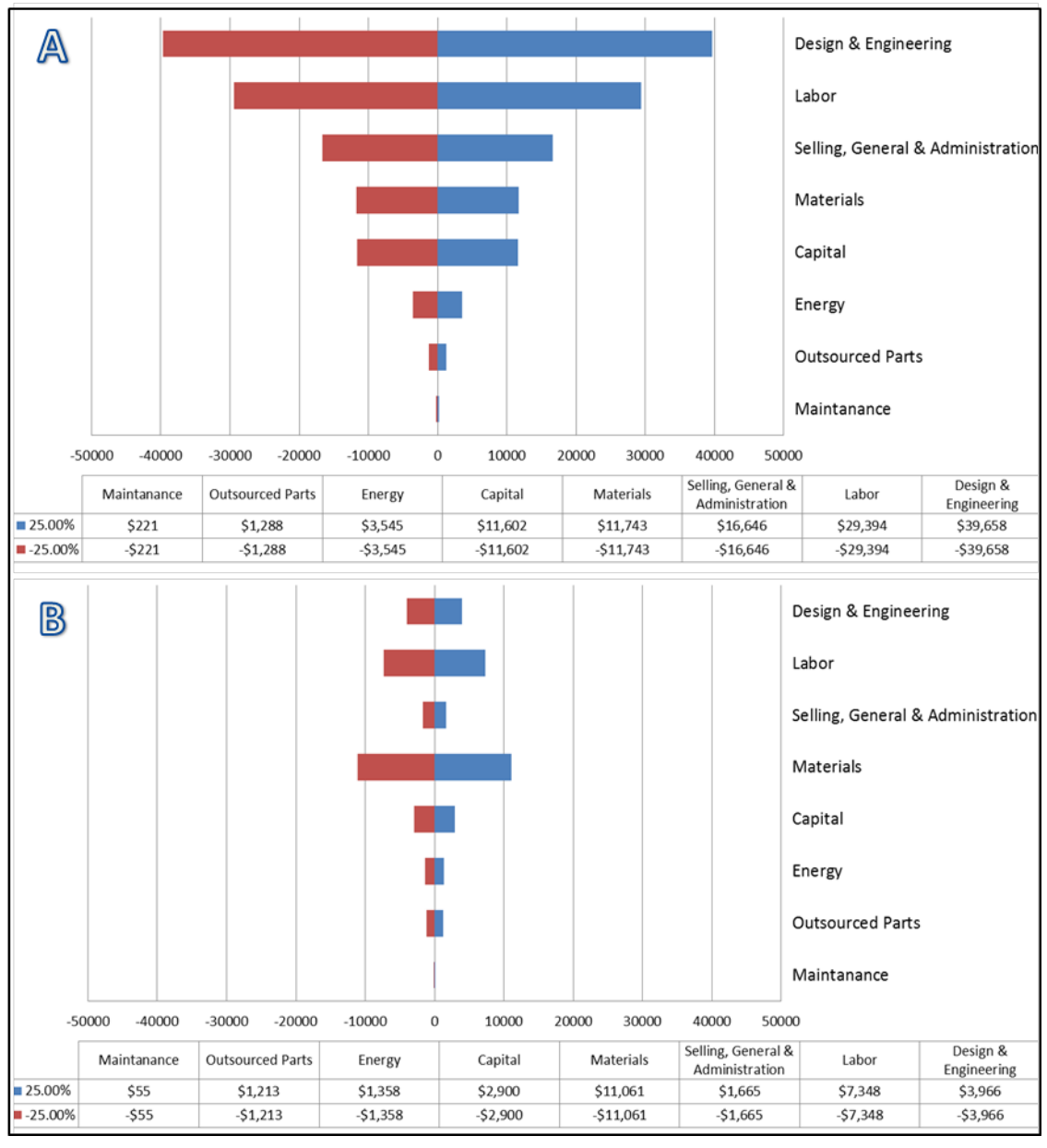

Figure 12 Sensitivity analysis for 5 MWe turboexpander based on A) Manufacturing volume of 1 unit/year (Custom Design) and B) Manufacturing volume of 10 units per year (Standard Design) in the United States (Data is from an ongoing CEMAC cost analysis).

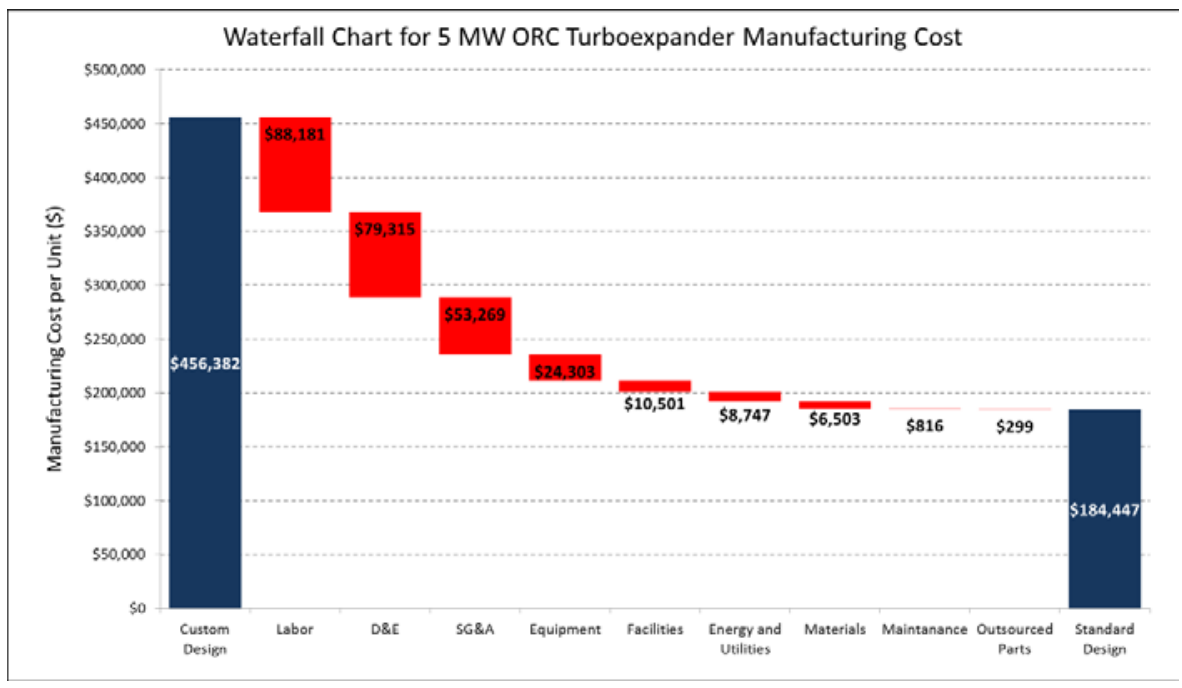

Figure 13 Manufacturing cost drop by cost factor for a standard design (10 units) 5 MWe ORC turboexpander (Data: ongoing CEMAC cost analysis) 


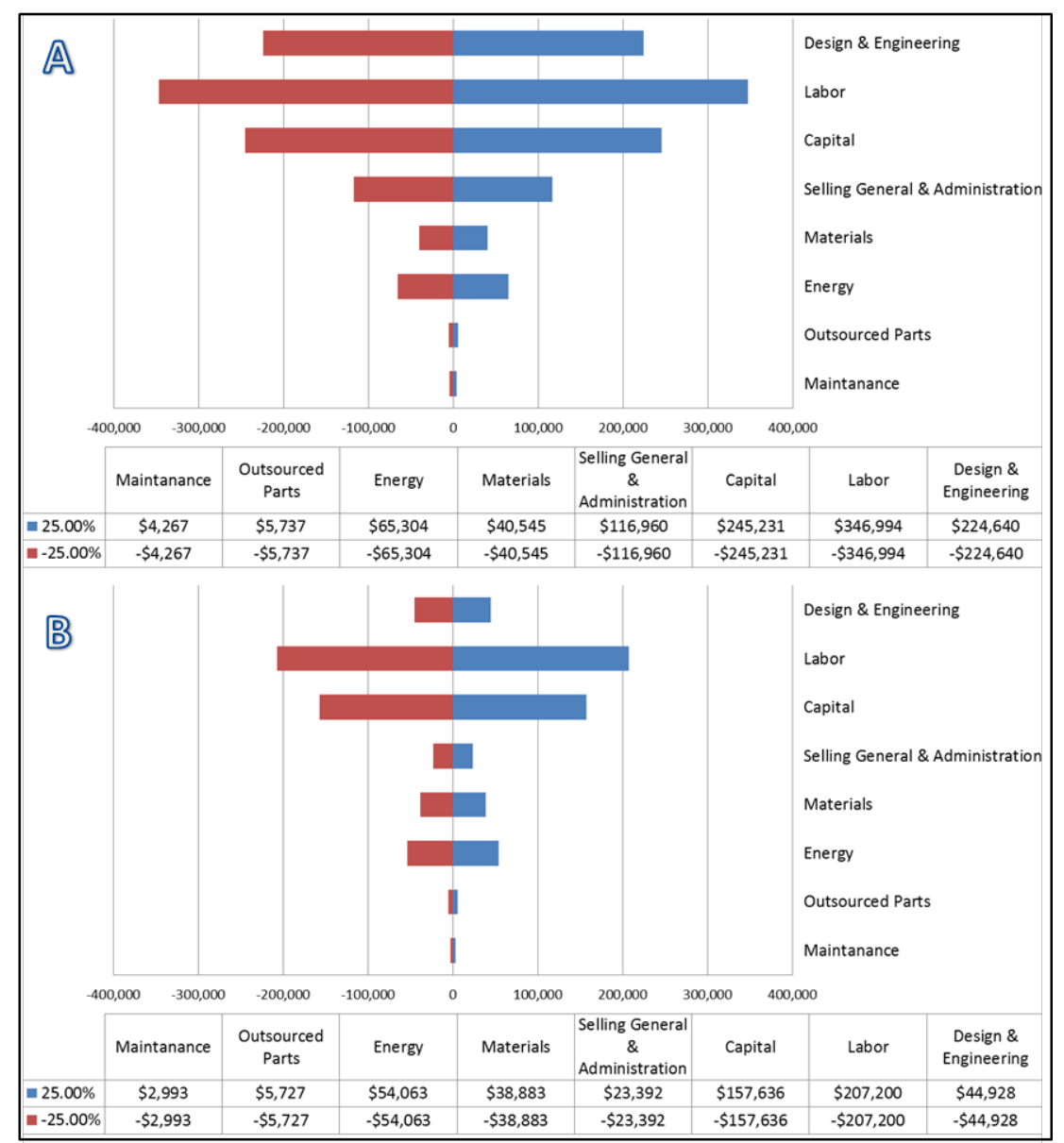

Figure 14 Sensitivity analysis for 20 MWe turboexpander based on A) Manufacturing volume of 1 unit per year (Custom Design) and B) Manufacturing volume of 5 units per year (Standard Design) in the United States (Data is from an ongoing CEMAC cost analysis).

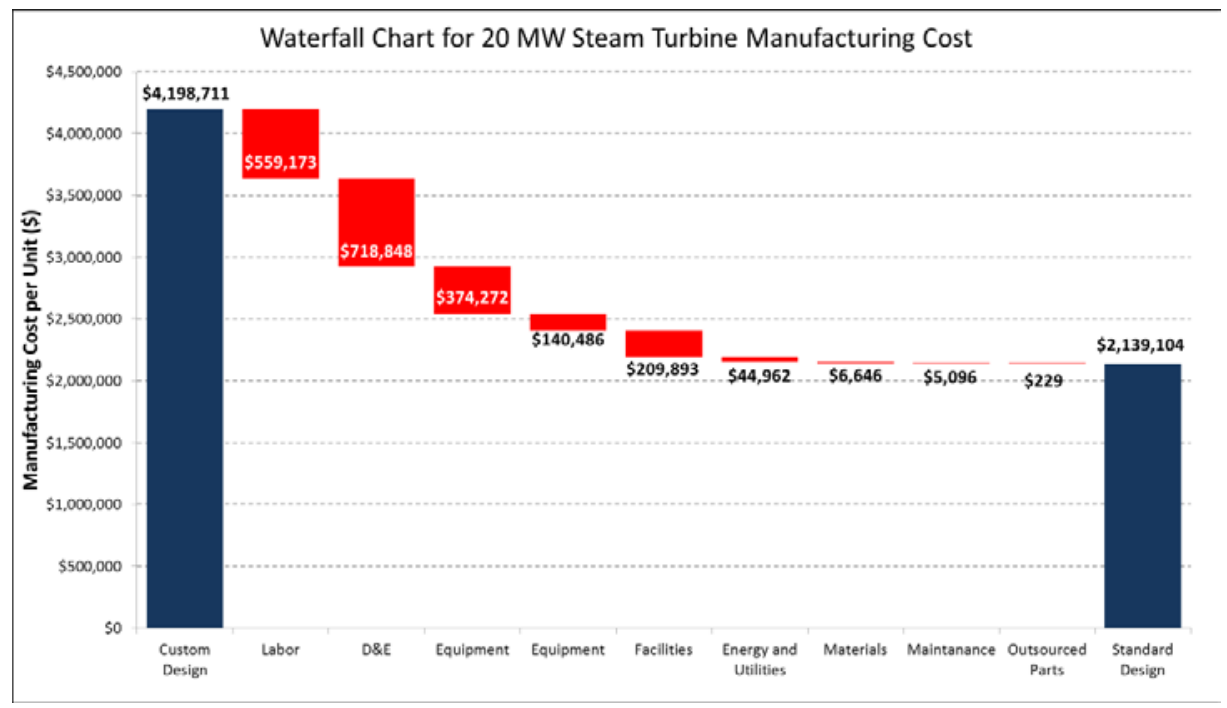

Figure 15 Manufacturing cost drop by cost factor for a standard design (5 units) 20 MWe steam turbine (Data: ongoing CEMAC cost analysis) 
A comparison of MSP analysis for all three cases can be found in Table 4. The manufacturing cost of custom design 5 MW ORC turboexpander is only $\$ 187,000$ more than a custom design 1 MW ORC turboexpander. This shows that the size of the turbine does not have a significant effect on the total cost of turbine/turboexpander. However, if we look at the unit cost per MW for both custom and standard design cases, we see that the manufacturing cost savings are significant (667 \$/kW for $1 \mathrm{MW}$ turboexpander and $150 \$ / \mathrm{kW}$ for $5 \mathrm{MW}$ turboexpander).

Table 4 Comparison of MSPs for standard and custom design turbines

\begin{tabular}{|c|c|c|c|c|c|c|}
\hline MSP & \multicolumn{2}{|c|}{$\begin{array}{l}\text { Custom Design } \\
\text { Single Unit }\end{array}$} & \multicolumn{2}{|c|}{$\begin{array}{l}\text { Standard Design } \\
\text { Volume of } 5 \text { Units }\end{array}$} & \multicolumn{2}{|c|}{$\begin{array}{l}\text { Standard Design } \\
\text { Volume of } 50 \text { Units }\end{array}$} \\
\hline $\begin{array}{l}1 \mathrm{MW} \\
\text { Turboexpander }\end{array}$ & $\$ 893,000$ & $893 \$ / k W$ & $226,000 \$$ & $226 \$ / k W$ & $\$ 74,000$ & $74 \$ / k W$ \\
\hline $\begin{array}{l}5 \mathrm{MW} \\
\text { Turboexpander }\end{array}$ & $\$ 1,080,000$ & $216 \$ / \mathrm{kW}$ & $332,000 \$$ & $66 \$ / \mathrm{kW}$ & $\$ 152,000$ & $30 \$ / \mathrm{kW}$ \\
\hline $\begin{array}{l}20 \text { MW Steam } \\
\text { Turbine }\end{array}$ & $\$ 6,350,000$ & $361 \$ / k W$ & $2,790,000 \$$ & $135 \$ / k W$ & N/A & N/A \\
\hline
\end{tabular}




\section{Power Plant Design and Performance Analysis}

The purpose of the turbine performance analysis is to determine the commercially favorable operating range of a standard ORC compared to custom-designed ORC equipment. We created a process flow model for an ORC Geothermal Power Plant at a given design point of the standard size (5 MW) turbine by using IPSEpro software (Figure 16). Balance of plant (BOP) is optimized to maximize power generation. In other words, the BOP, including Heat Exchanger $(\mathrm{HX})$, air cooled condenser (ACC), pumps, and piping, can be designed to optimize turbine output. The design assumptions for the optimized system include; 1) the pinch point temperature difference in heat exchanger, 2) vapor quality into the turbine and 3) turbine efficiency.

We selected the design point at $175^{\circ} \mathrm{C}$ inlet brine temperature and $80 \mathrm{~kg} / \mathrm{s}$ brine mass flow rate for the standard turbine. Then, we ran an optimization algorithm to optimize BOP and operating conditions by adjusting the pressure before and after turbine for maximum turbine output at given geothermal inputs. The performance of the standard turbine is compared to a custom design turbine by running off-design models for varying geothermal resource temperatures (between $160^{\circ} \mathrm{C}$ and $190^{\circ} \mathrm{C}$ ), and brine flow rates (between $40 \mathrm{~kg} / \mathrm{s}$ and $120 \mathrm{~kg} / \mathrm{s}$ ). A turbine off-design efficiency curve ${ }^{1}$ provided by a reliable manufacturer as a function of mass flow rate of the working fluid is used to evaluate the impact on power generation of the standard versus custom design (Figure 17). The design point isentropic efficiency is selected as $80 \%$.

One important parameter that we use in the plant performance analysis is the Brine Effectiveness (BE). Simply, BE is the amount of energy that you can extract per pound of geothermal brine or steam, which is defined as net plant output divided by the brine flow rate (w-hr/lb). The use of BE to describe plant performance comes from the Geothermal Technology Evaluation Model (GETEM, 2016) on which the SAM geothermal module is based.

\footnotetext{
${ }^{1}$ Due to the proprietary nature of turbine performance curves, we could not obtain a full set of turbine performance curves. The turbine efficiency curve we used shows relative efficiency as a function of relative working fluid mass flow rate at a constant isentropic enthalpy drop across the turbine. The curve does not account for changes in isentropic enthalpy drop. in the IPSEpro modeling, both the working fluid mass flow rate and isentropic enthalpy drop across the turbine vary. However, the turbine model only considers working fluid mass flow rate when adjusting turbine isentropic efficiency. The resulting efficiency curve is likely not representative of actual turbine performance and is used only for illustrative purposes in this report. Turbine manufacturers and project developers have access to actual turbine performance curves and can use the methodology in this report to assess potential benefits of a standard turbine design.
} 


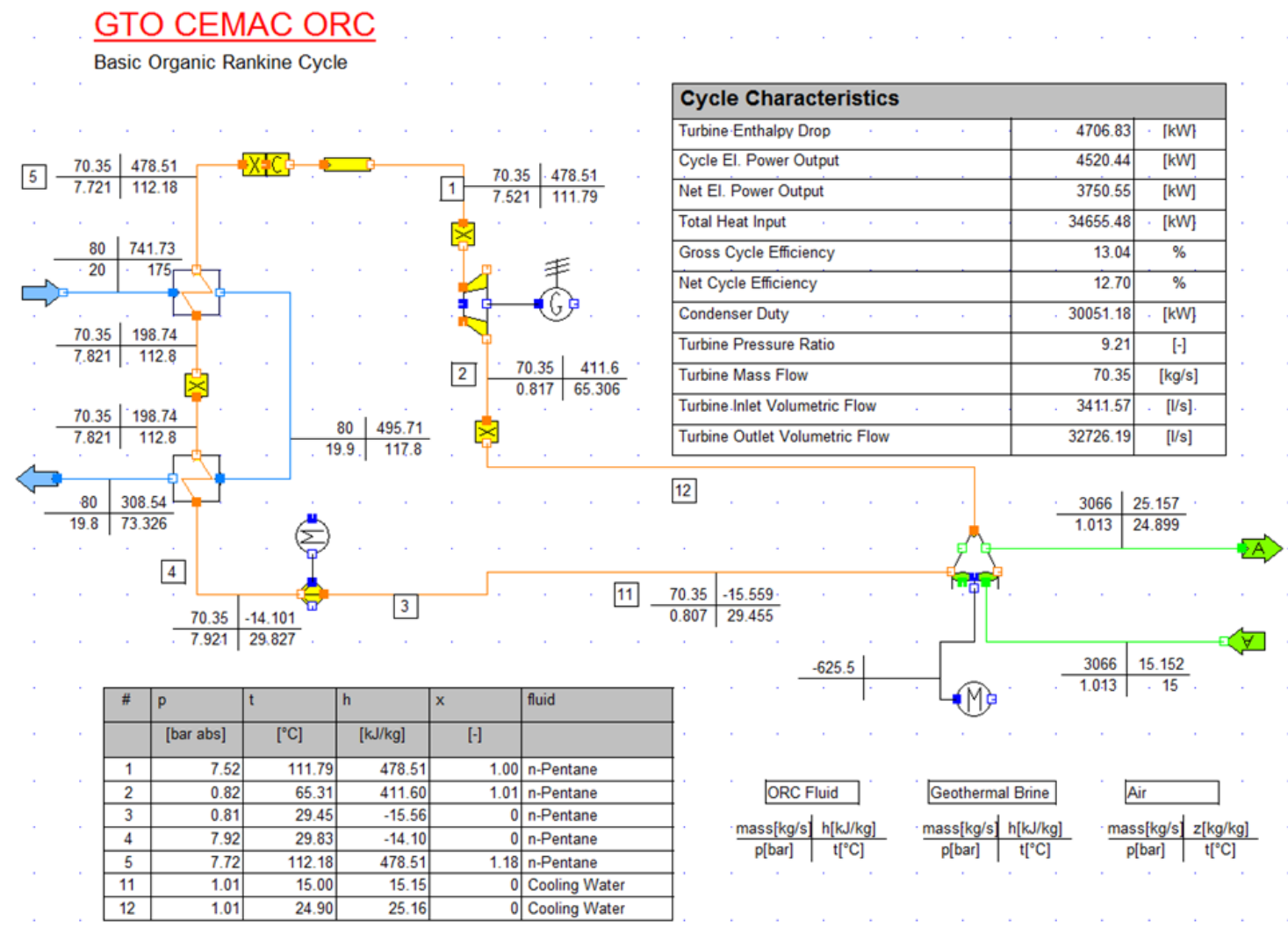

Figure 16 Process Flow Diagram of Standard Size ORC Power Plant

In SAM, BE is set by adjusting the plant efficiency input. According to IPSEpro modeling results, the $B E$ of binary plants studied varies between 3.3 and $7.5 \mathrm{w}-\mathrm{hr} / \mathrm{lb}$ (Figure 18). This value is 5.9 $\mathrm{w}$-hr/lb for the standard turbine at its design point in IPSEpro. The BE value determines the more conventional thermal to electric conversion efficiency (TE) of the plant. TE varies as a function of inlet geothermal brine temperature and mass flow rate (Figure 19). TE is calculated as $10.83 \%$ at the design point for the base case IPSEpro model. 


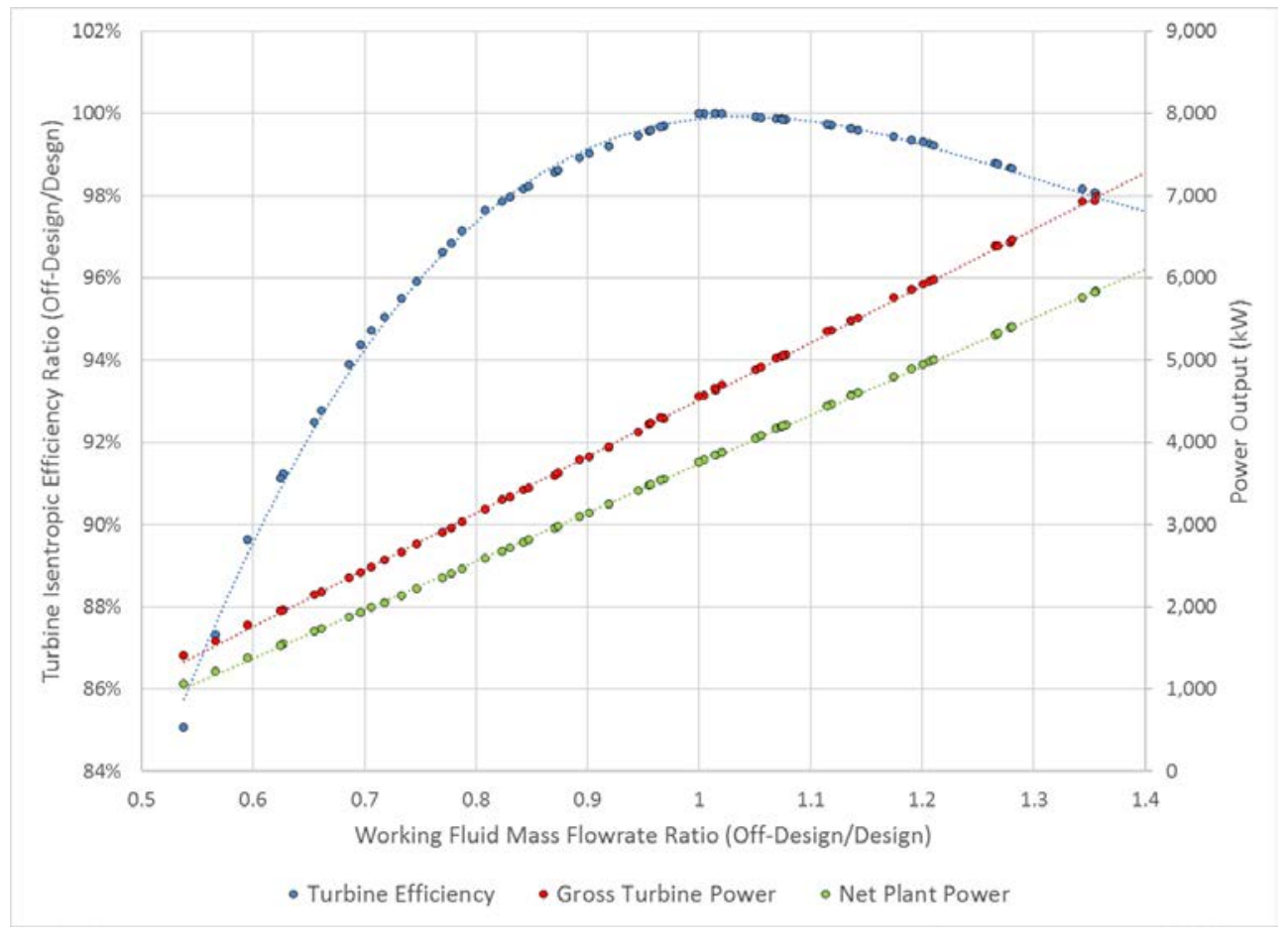

Figure 17 Off-Design Turbine Efficiency Curve

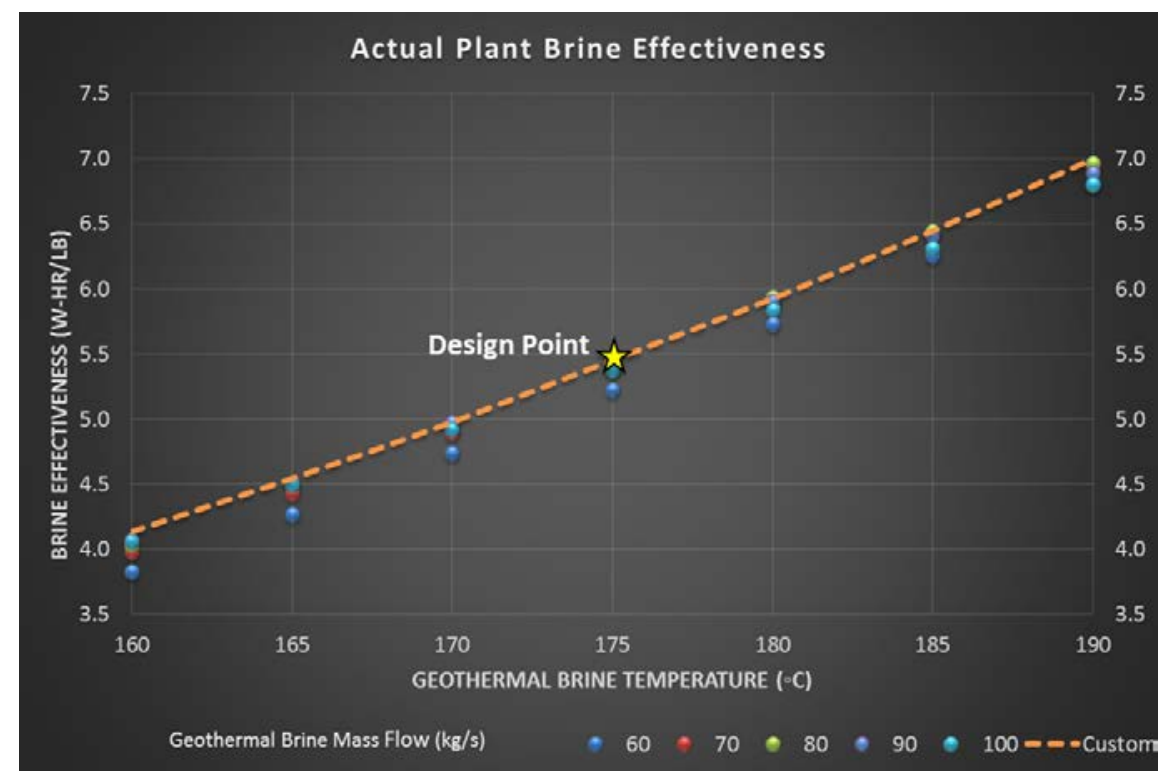

Figure 18 Actual Plant Brine Effectiveness 


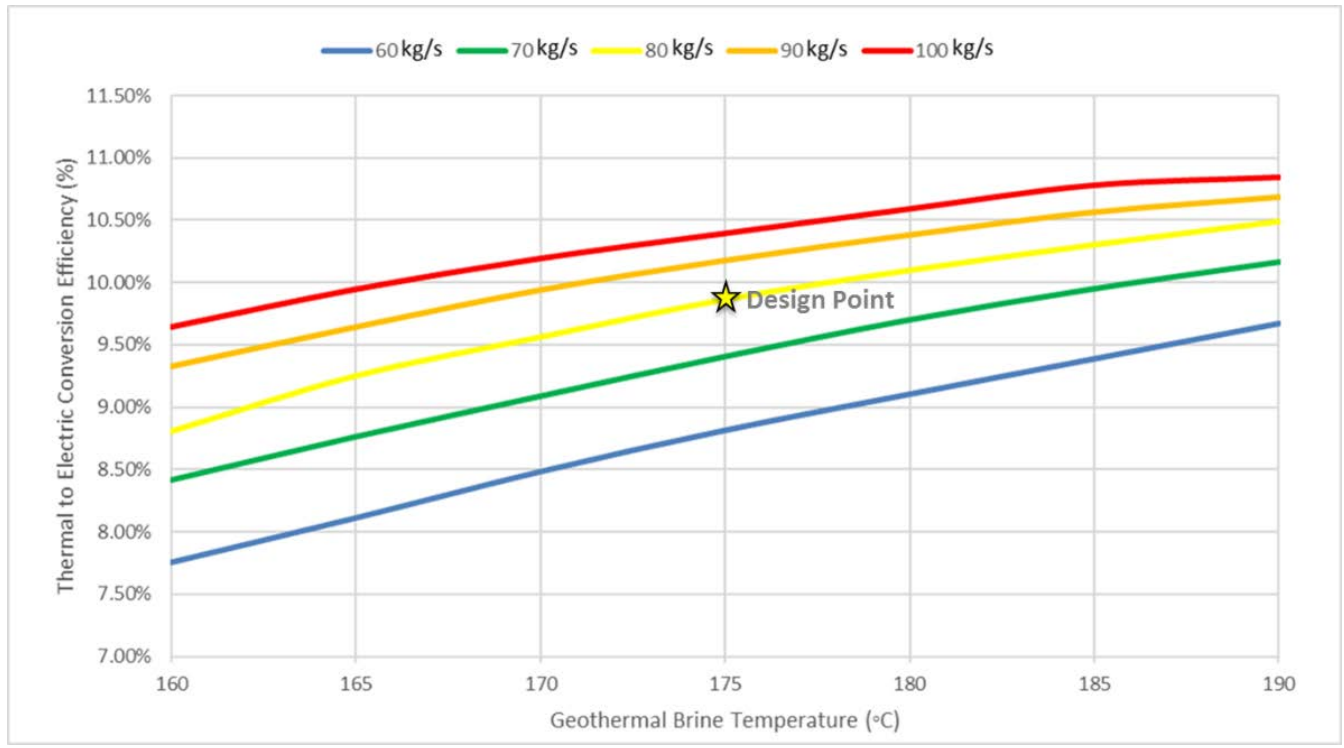

Figure 19 Thermal to electric conversion efficiency for 5 MWe ORC turbine 


\section{Economic Analysis}

We focused on monetizing the processes developed in power plant performance modeling for our economic analysis, which helped us to convert performance calculations and power output into a DCF analysis of plant operations and financing, thereby creating representative technoeconomic models of a total geothermal power plant. We used SAM and performed DCF analysis of standard and custom design turbines using results from IPSEpro over the range of geothermal resource temperatures and flow rates of interest. We applied the base case inputs for geothermal resource to SAM inputs and established a base case model (Table 5). A single owner PPA financial model was selected for financial analysis.

Table 5 Base Case Geothermal Resource Characterization for SAM financial Model

\begin{tabular}{|c|c|c|}
\hline Parameter & Unit & Value \\
\hline Resource Temperature & C & 175 \\
\hline Reservoir pressure change per $1000 \mathrm{lb}$ & psi-h & 0.35 \\
\hline Reservoir Depth & $\mathrm{m}$ & 2000 \\
\hline Temperature Decline Rate & $\% / y r$. & 0.3 \\
\hline Number of Production Wells & - & 1 \\
\hline Production Well Flow Rate & $\mathrm{kg} / \mathrm{s}$ & 80 \\
\hline Number of Injection Wells & - & 1 \\
\hline
\end{tabular}

To compare projects and results on a common basis, the "exact number of wells" option is chosen in SAM and the number of production wells is set at one. For the base case, this results in a gross turbine output power capacity (nameplate capacity) of $\sim 5 \mathrm{MW}$, so that the power plant cost values from the MSP analysis can be used.

SAM allows the user to set "Plant Efficiency (\%)", which sets the plant BE as a percentage of the Maximum Brine Effectiveness (limit from GETEM). Setting Plant Efficiency to $100 \%$ gives plant with BE equal to the maximum brine effectiveness. Setting Plant Efficiency to $50 \%$ gives a plant with brine effectiveness equal to $50 \%$ of max BE. Using this data, we back-calculated the Plant Efficiency needed to match BE values from IPSEpro runs. We set the binary plant efficiency to $65.1 \%$ to match to IPSEpro BE results in $\mathrm{w}-\mathrm{hr} / \mathrm{lb}$ for the base case.

We developed system cost scenarios for custom design and standard design turbines. The SAM version of GETEM does not currently include the ability to automatically estimate plant cost, but the Excel version of GETEM does. Therefore, we used GETEM to estimate the plant costs and imported those values in SAM. For the custom design scenarios, the plant size and efficiency results from the IPSEpro model were used as inputs to GETEM to estimate the plant 
costs. Plant costs in GETEM are determined by estimating the individual costs for the major plant components (turbine, heat exchangers, condenser and working fluid pump) and using a direct-cost multiplier to account for piping, instrumentation, etc. and construction costs. This value was then used as the input for the "Specified Plant Cost" in SAM. For the standard design scenarios, the same individual component costs and direct cost multiplier were used, but the turbine cost was decreased by $\$ 150 / \mathrm{kW}$ to reflect the cost savings from using a standard turbine design (see Table 4). Results from IPSEpro were used as the BE (plant efficiency) inputs in SAM for the custom and standard scenarios to account for the reduced efficiency of the standard turbine (compared to the custom turbine) when it operates at off-design conditions.

For the DCF analysis, we developed a business model with standard financial assumptions for all scenarios (Table 6). Changes in financial parameters would affect the NPV of costs. The simplest business model is a $100 \%$ equity model in which the developer pays cash for the project at the time of start of operations. In this case, the standard turbine is not competitive compared to a custom turbine. Realistically, the more you defer costs to the future (debt) or offset costs in the future (depreciation, tax advantages), the more the custom turbine design would be favored. In our model, we selected $60 \%$ debt ratio to optimize NPV calculations.

Table 6 Financial parameters for SAM Model

\begin{tabular}{|c|c|c|}
\hline Parameter & Unit & Value \\
\hline PPA price & $\Phi / \mathrm{kWh}$ & 10.00 \\
\hline Annual escalation rate & $\%$ & 1.00 \\
\hline IRR Target & years & 20.00 \\
\hline Project debt ratio & $\%$ & 60.00 \\
\hline Real discount rate & $\% / y r$ & 5.5 \\
\hline Inflation rate & $\%$ & 2.5 \\
\hline Nominal Discount Rate & $\% / y r$ & 8.15 \\
\hline Annual interest rate & $\%$ & 7.00 \\
\hline Incentives (PTC/ITC) & $\$$ & 0.00 \\
\hline Depreciation Structure (5 Years MACRS) & $\%$ & 100.00 \\
\hline
\end{tabular}




\subsection{Decision Criteria used in SAM Financial Model}

The decision criteria of the SAM financial model are functions of:

- Electricity generated

- PPA price

- Analysis period

- Project equity investment amount

- Annual project costs

- Discount rate

PPA price is the bid price in a power purchase agreement (PPA) and is the price that the project receives for each unit of electricity that the system generates. Levelized PPA uses the discount rate to determine the present value of the project's PPA revenue over its lifetime. For the PPA models, SAM assumes that the project sells all the electricity generated by the system at a price negotiated through a power purchase agreement (PPA). A financially viable project is likely to have a levelized cost that is equal to or less than the levelized PPA price to cover project costs and meet internal rate of return (IRR) requirements.

The internal rate of return (IRR) is a measure of the project's profitability and is defined as the nominal discount rate that corresponds to a net present value of zero (Mendelsohn et al, 1995; Short et al, 2012). Using "Specify IRR Target" makes SAM uses a search algorithm to find the PPA price required to meet the target IRR. SAM reports IRRs and NPVs for the project.

The NPV is the present value of the after-tax cash flow discounted to year one using the nominal discount rate. PPA price determines annual revenue. Net capital cost is the sum of the total installed cost and debt, other financing fees, and reserve funding from the Financial Parameters page, less investment-based and capacity-based incentives. SAM also allows the user to specify parameters for up to five construction loans to approximate interest during construction (IDC) that SAM considers to be a cost to the project. The Project Term Debt input variables determine the size of debt or amount borrowed and debt-related costs. Real Discount Rate is a measure of the time value of money expressed as an annual percentage. SAM's financial model results are very sensitive to the real discount rate input (Mendelsohn et al, 1995; Short et al, 2012).

The levelized cost of Electricity (LCOE) calculator uses a simple method to calculate the project's LCOE. The user provides the installation cost, operating costs, and a fixed charge rate as input, and the model calculates the LCOE based on the annual energy generated by the system. The calculator can also calculate the fixed charge rate when you provide basic financial parameters. The list of financial parameters which are required to calculate financial outputs can be found in Table 7. 
Table 7 Summary of financial parameters used to calculate financial outputs

\begin{tabular}{|c|c|c|c|c|c|c|c|}
\hline & $\begin{array}{l}\text { PPA } \\
\text { (revenue) }\end{array}$ & $\begin{array}{l}\text { Discount } \\
\text { Rate }\end{array}$ & $\begin{array}{l}\text { Project } \\
\text { Costs }\end{array}$ & Expenditures & $\begin{array}{l}\text { Electricity } \\
\text { Generation }\end{array}$ & $\begin{array}{l}\text { IRR } \\
\text { Target } \\
\text { Year }\end{array}$ & $\begin{array}{l}\text { Analysis } \\
\text { Period }\end{array}$ \\
\hline IRR & $x$ & & $x$ & $x$ & & $x$ & \\
\hline NPV & $x$ & $x$ & $x$ & $x$ & & & $x$ \\
\hline LCOE & $x$ & $x$ & $x$ & $x$ & $x$ & & $x$ \\
\hline Levelized PPA & $x$ & $\mathbf{x}$ & & & $x$ & & $x$ \\
\hline
\end{tabular}

\subsection{SAM Model Results and Discussions}

To start with, we ran the SAM model for the custom design and standard design turbine for the base case $\left(175^{\circ} \mathrm{C}\right.$ temperature and $80 \mathrm{~kg} / \mathrm{s}$ mass flow rate), where it is assumed that the standard and custom turbine designs have identical performance. Net electricity generation capacity is used to calculate annual revenue from electricity sales. The results showed that the standard design turbines provide savings at the net capital cost and result in a higher NPV and IRR for the project at the given base case conditions (Table 8). While the net capital cost saving may reach up to $+\$ 2,312,300$, the difference between the NPV of standard design and custom design turbines could reach up to $+\$ 1,440,410$.

Table 8 Comparison of SAM financial model results for custom and standard design scenarios

\begin{tabular}{|l|l|r|r|}
\hline Metric & & Custom Design (Base Case) & Standard Design (Base Case) \\
\hline Levelized COE (nominal) & C/kWh & 10.49 & 9.82 \\
\hline Levelized COE (real) & C/kWh & 8.13 & 7.61 \\
\hline Net present value (NPV) & $\$$ & $\$ 1,346,430$ & $\$ 2.786 .840$ \\
\hline Internal rate of return (IRR) & $\%$ & $7.20 \%$ & $11.99 \%$ \\
\hline Year IRR is achieved & year & 20 & 20 \\
\hline IRR at end of project & $\%$ & $10.03 \%$ & $13.66 \%$ \\
\hline Net capital cost (NCC) & $\$$ & $\$ 24,456,800$ & $\$ 22,144,500$ \\
\hline Equity & $\$$ & $\$ 9,782,720$ & $\$ 8,857,800$ \\
\hline Size of debt & $\$$ & $\$ 14,674,080$ & $\$ 13,286,700$ \\
\hline NCC Difference & $\$$ & & $\mathbf{+ \$ 2 , 3 1 2 , 3 0 0}$ \\
\hline NPV Difference & $\$$ & & $\mathbf{+ \$ 1 , 4 4 0 , 4 1 0}$ \\
\hline
\end{tabular}

Then, we extended the financial analysis over 63 off-design cases by changing inlet geothermal brine temperature (between $160^{\circ} \mathrm{C}$ and $190^{\circ} \mathrm{C}$ ) and inlet mass flow rate (between $40 \mathrm{~kg} / \mathrm{s}$ and $120 \mathrm{~kg} / \mathrm{s}$ ). The standard turbine's power generation capacity is taken as $5 \mathrm{MW}$ with off design power outputs ranging between 1.4 MW and 6.9 MW gross. The results for standard turbines operating at off-design conditions showed that: 
- Net capital cost in $\$ / \mathrm{kW}$ significantly decreases with respect to increasing geothermal brine temperature and mass flow rate (Figure 20).

- The standard turbines are competitive over a wide range of temperatures and flow rates and give positive NPV for cases near the design point (Figure 21)

- Standard turbines are more cost effective than custom turbines near the design point, and less cost effective away from it. Because the standard turbine cannot perform at higher isentropic efficiency than the custom turbine. It can only be equal or less.

- The NPV difference between standard and custom design scenarios show 45 of 63 test cases that resulted in positive values where standard design turbines are favorable (Figure 22).

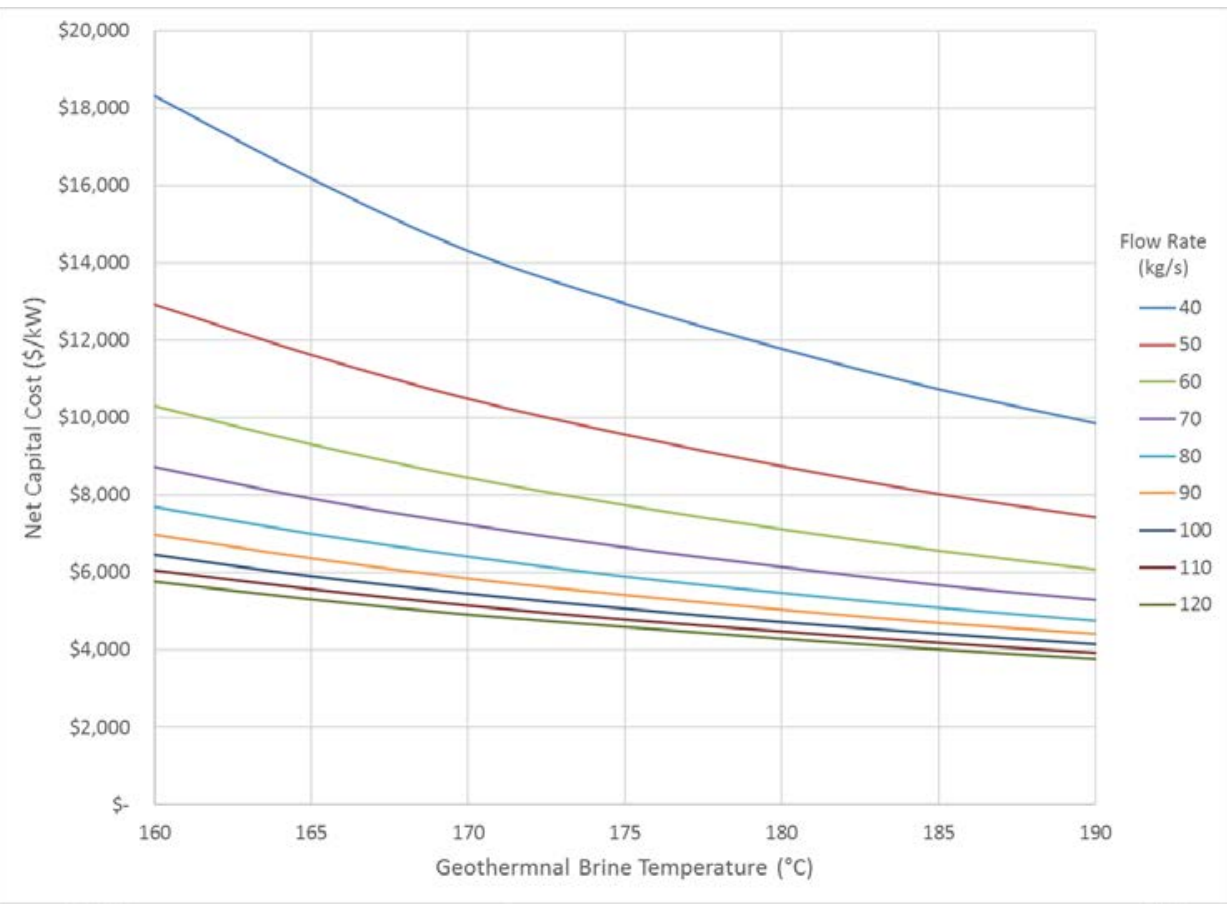

Figure 20 Net capital cost per kW for different off-Design cases of the standard turbine

Using a standard turbine design results in an NPV that is higher than using a custom turbine design over a large range of geothermal brine temperatures and flow rates, as shown in Figure 22. The highest relative NPV results tend to be at elevated geothermal brine temperatures and flow rates. The figure does not consider practical limitations on the power output from the standard turbine. The actual output from the model can be much larger than the design output of 5,000 kW as shown in Figure 23. In practice, a turbine would not be able to operate at this high an output above its design point. We do not have the technical information to estimate exactly what the cut off output would be for the standard design, but we can conclude that a large portion of the upper right part of Figure 22 is not in the practical operating range of the 
standard turbine design. Turbine manufacturers and project developers should keep these limitations in mind when evaluating the results of this study.

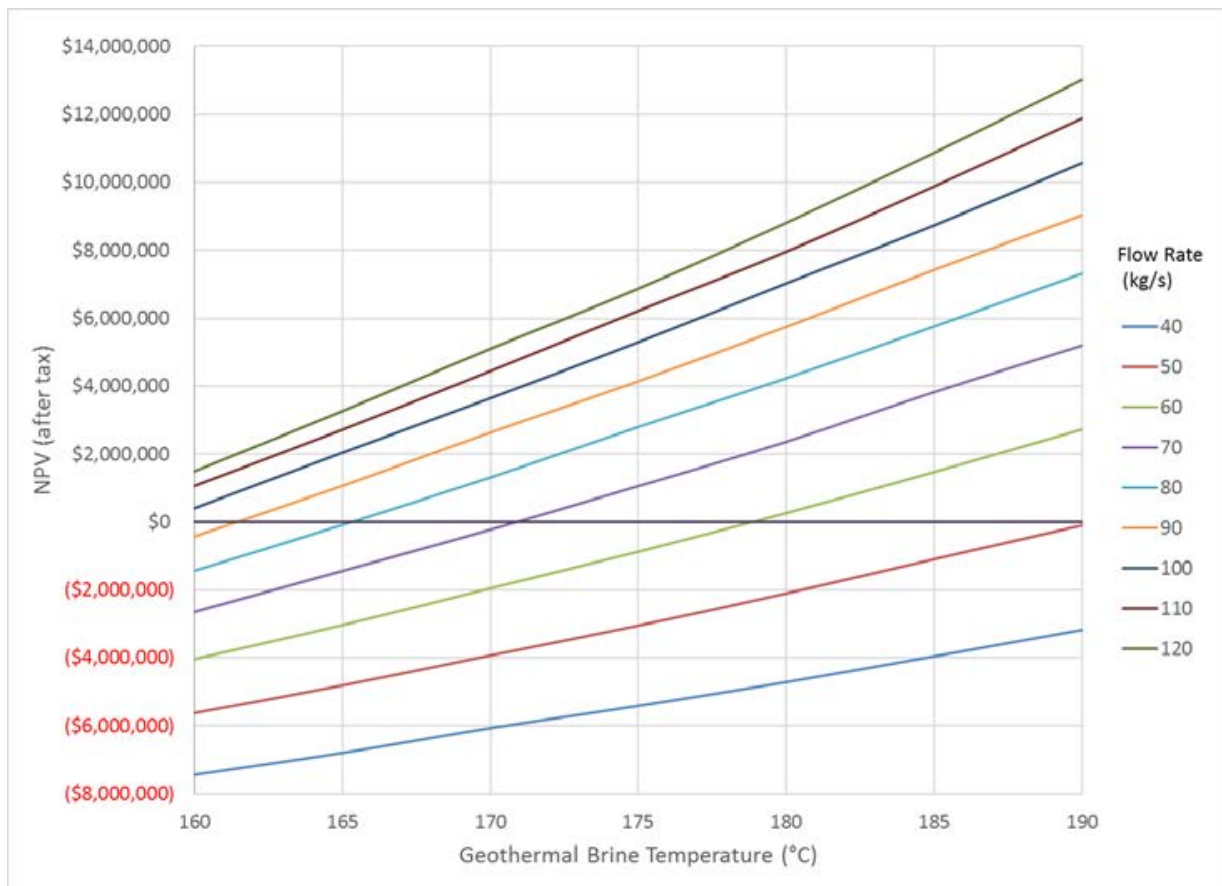

Figure 21 NPV after tax for different off-design cases of the standard turbine 
NPV Difference Between Standard and Custom Design Scenarios

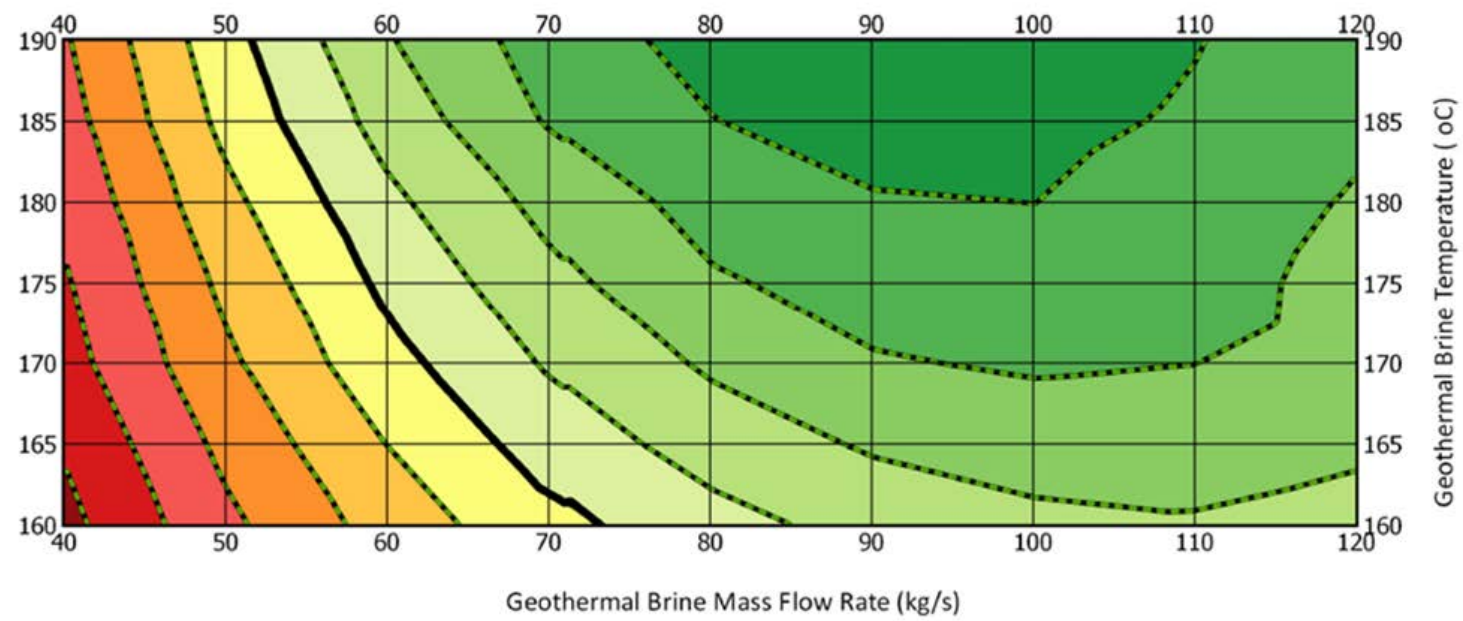

\begin{tabular}{|c|c|}
\hline NPV Difference (\$) (Negative) & NPV Difference (\$) (Positive) \\
\hline$<-2,500,000$ & $0-500,000$ \\
\hline$-2,000,000-(-2,500,000)$ & $500,000-1,000,000$ \\
\hline$-1,500,000-(-2,000,000)$ & $1,000,000-1,500,000$ \\
\hline$-1,000,000-(-1,500,000)$ & $1,500,000-2,000,000$ \\
\hline$-500,000-(-1,000,000)$ & $>2,000,000$ \\
\hline$-500,000-0$ & NPV Difference $=0$ (Economic Boundary $)$ \\
\hline
\end{tabular}

Figure 22 NPV difference between custom and standard design scenarios for given resource conditions. Green colored areas with positive values represent cases where standard design turbines are favorable. Black solid line represents the economic boundary of standard turbines where NPV difference is zero. 


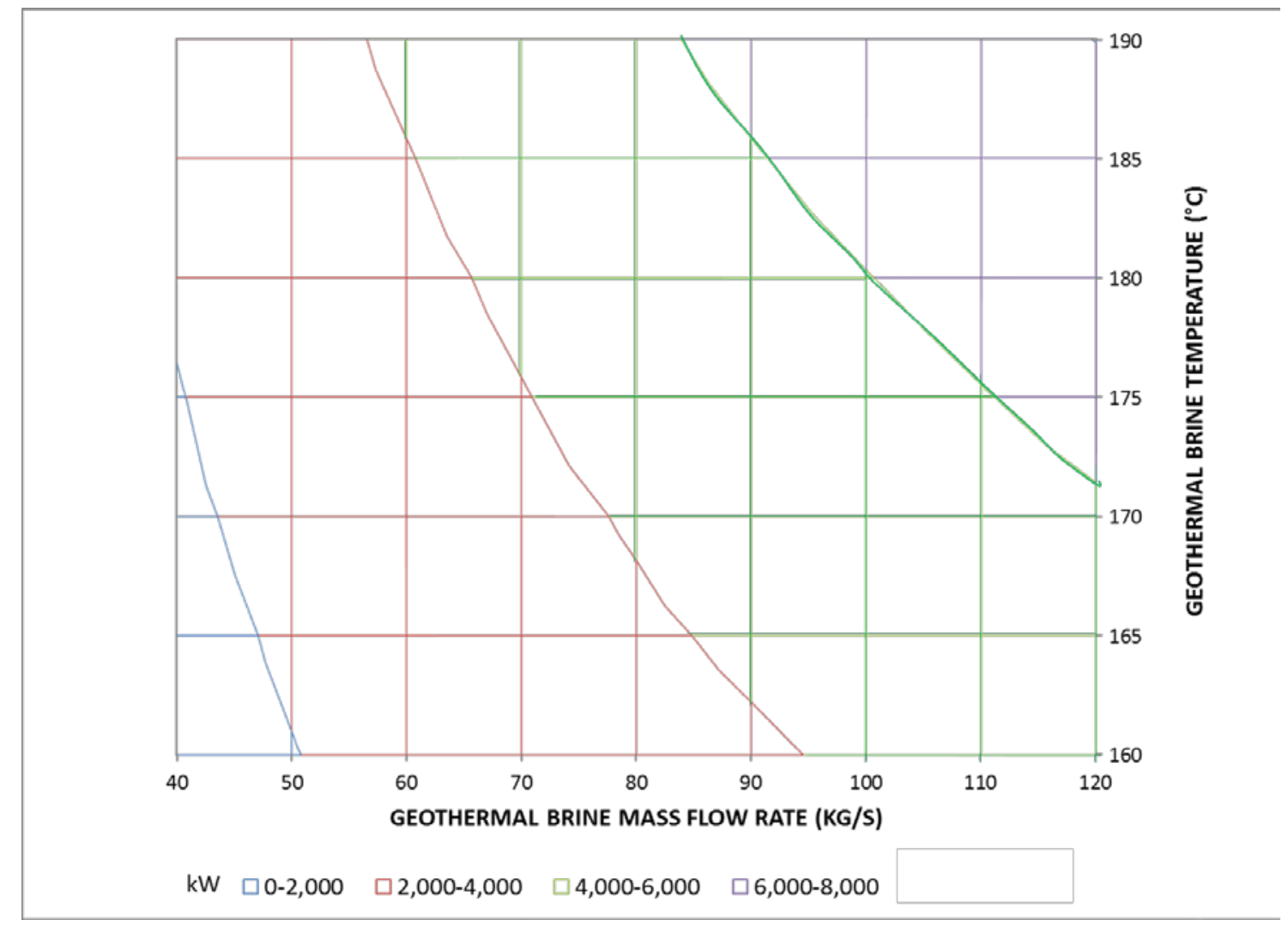

Figure 23 Standard turbine design gross turbine output in $\mathrm{kW}$ as a function of geothermal brine temperature and flow rate. Standard turbine design output (nameplate capacity) is 5,000 kW.

\subsubsection{Sensitivity Analysis}

As described in Section 5, we did not have access to a full turbine performance curve for this analysis. Therefore, the results above are only illustrative of the relative costs and performance of standard and custom turbine designs. Although we did not have the data to accurately model off-design turbine performance, we did have the information necessary to determine the relative efficiency at which a standard turbine design is cost competitive with a custom turbine design. We conducted a sensitivity analysis on the impact of turbine performance on the NPV of the power plant. We iteratively varied geothermal brine temperature and flow rate to calculate the isentropic turbine efficiency at the break-even NPV point (Figure 23). In other words, we set the relative isentropic efficiency of the turbine to achieve the NPV of the custom plant equal the NPV of the plant with a standard turbine. This is the economic boundary between the standard design and custom design turbines.

For the sensitivity analysis, 63 test case scenarios are taken, and 1008 observation points are generated for different relative isentropic efficiencies with respect to the design point ranging between $85 \%$ and $100 \%$. The results for select cases (minimum, design, and maximum geothermal brine temperature and flow rates) are shown in Figure 24 and for all cases in Figure 25. In these figures, the standard turbine design is cost competitive at a given relative isentropic efficiency if the NPV difference (standard design NPV minus custom design NPV) is 
positive. There is a large range of relative isentropic efficiencies over which the standard turbine design is cost competitive for the maximum and design geothermal brine temperatures and flow rates (Figure 24). For the lowest geothermal brine flow rate and temperature, the standard design is not competitive, even at $100 \%$ relative efficiency.

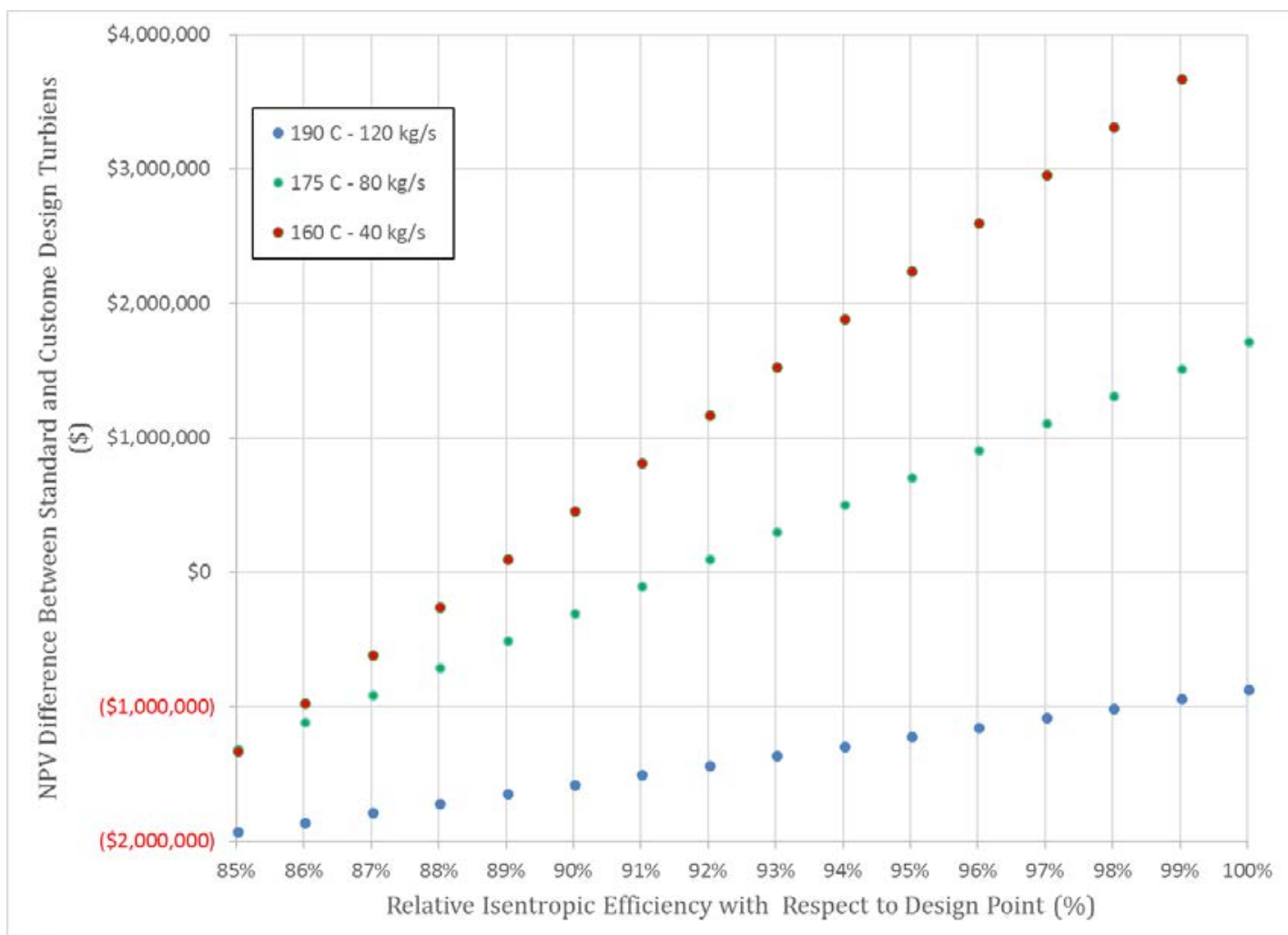

Figure 24. Sensitivity analysis for NPV difference with respect to relative isentropic efficiencies for select cases

The correlation between the NPV difference vs. relative efficiency is linear (Figure 25). By fitting a linear curve to each case and calculating the relative efficiency where the NPV is zero, we determined the breakeven isentropic efficiency for each case, or the relative isentropic efficiency of the standard turbine necessary to make the project cost competitive with a custom turbine design.

The results of this analysis are shown in Figure 26. The results showed that the NPV of the project is sensitive to turbine isentropic efficiency. This also implies that a detailed turbine efficiency analysis is needed for more precise economic analysis. 


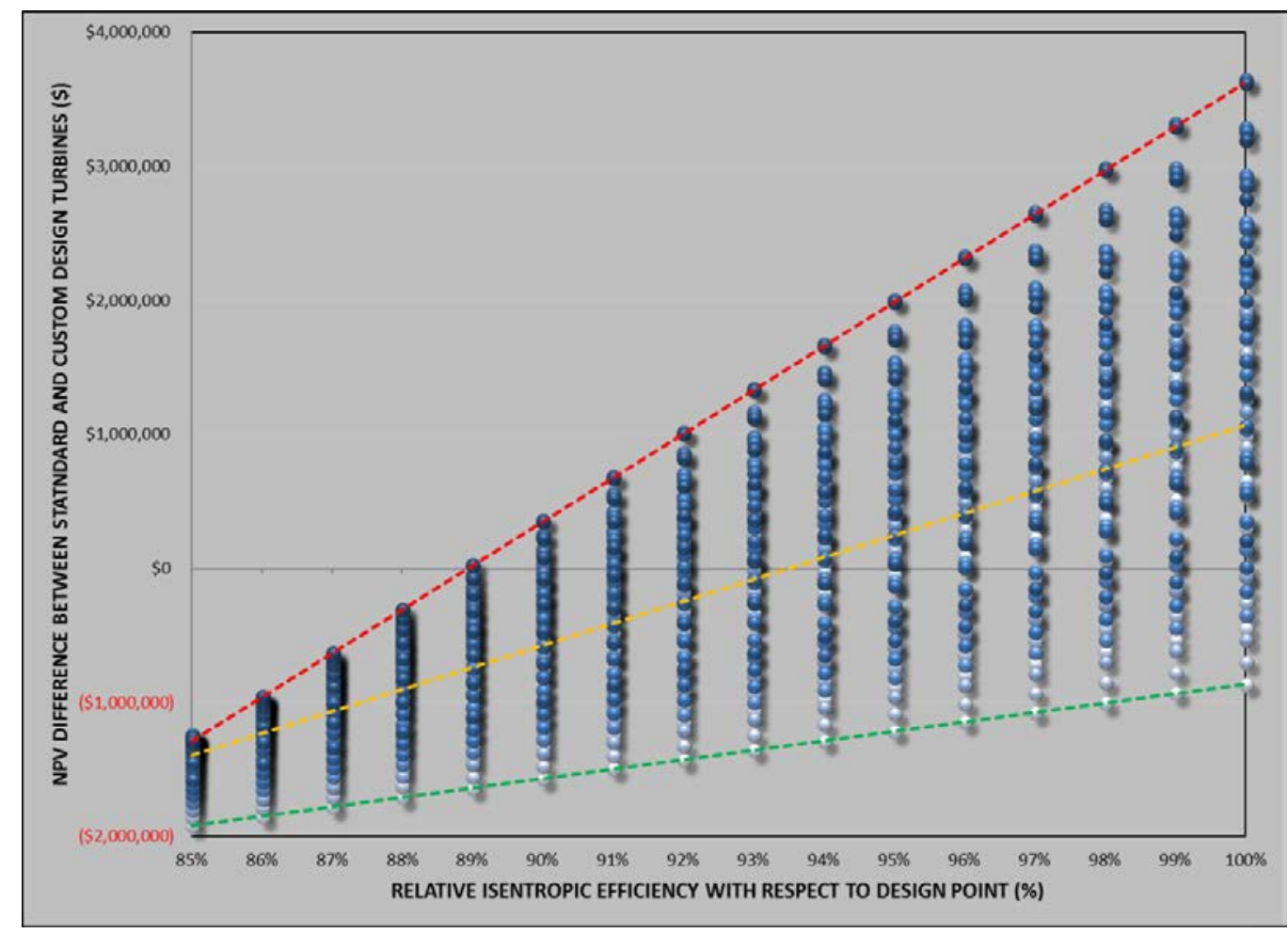

Figure 25 Sensitivity analysis for NPV difference with respect to relative isentropic efficiencies for all cases (Green, yellow and red dashed lines represent the lower limit, median and upper limit respectively.)

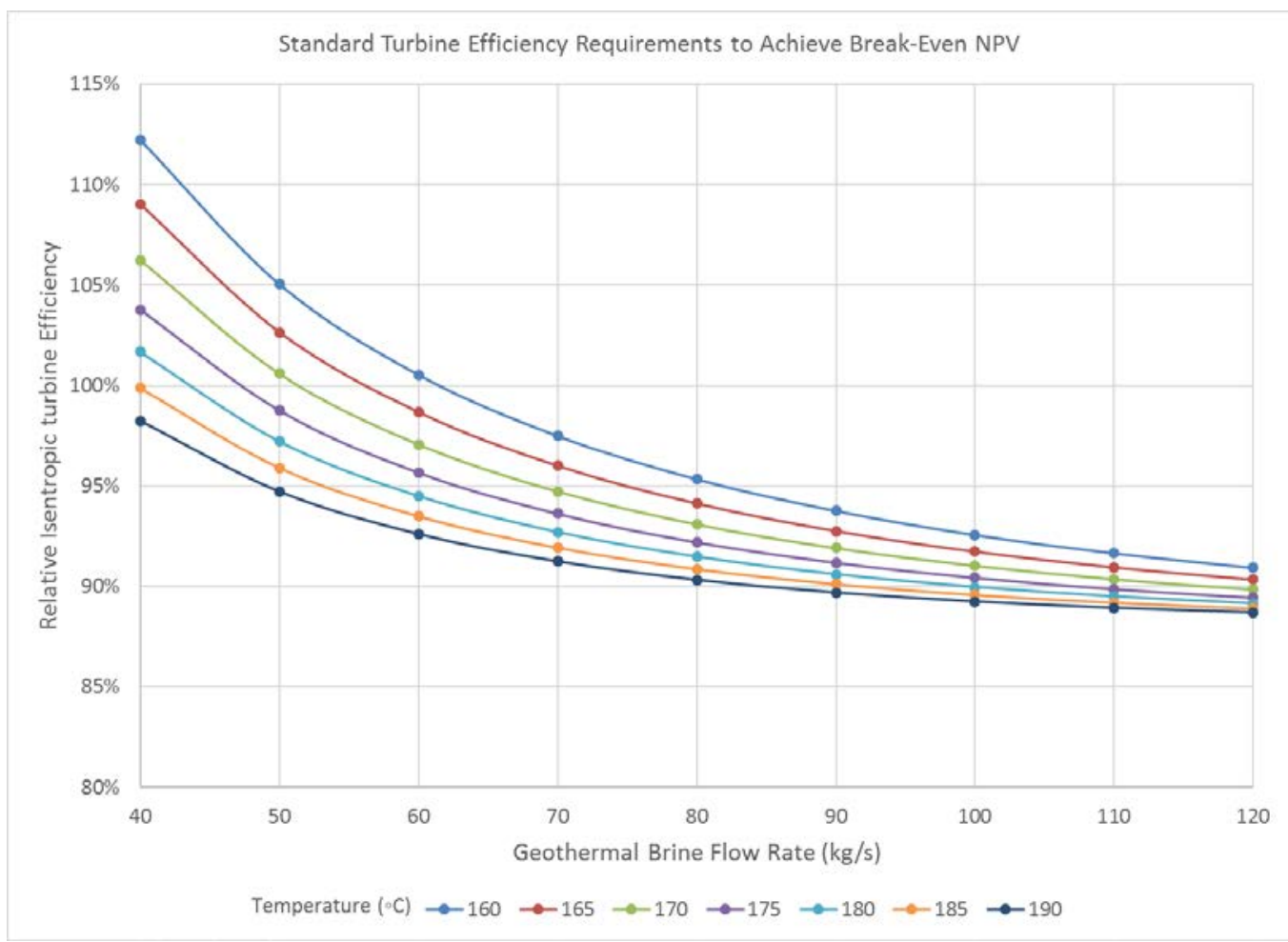

Figure 26 The required isentropic efficiency of the standard turbine relative to a custom turbine to get a break-even NPV. 
Figure 26 shows that for lower temperature and flow rates, a standard turbine requires an isentropic efficiency greater than zero to be cost competitive. The reason for this is illustrated by Figure 27, which shows the total plant cost savings from using a standard turbine design vs. a custom turbine design for each case. The standard turbine cost is fixed for each case, while the custom turbine cost depends on its size and efficiency. At low geothermal brine temperatures and flow rates, where the plant power output is lower, the plant cost for the custom turbine is lower than for the standard turbine because of the small turbine size. To compensate, the standard turbine would have to operate at a higher efficiency and generate more electricity than the custom turbine to be cost competitive. This illustrates that at some point, building a smaller custom turbine at a higher $\$ / \mathrm{kW}$ cost offsets the cost savings from a standard (but oversized) turbine. This is the type of information that a manufacturer would need to consider when deciding on what sizes or design power generation capacity to choose for a series of standard turbine designs.

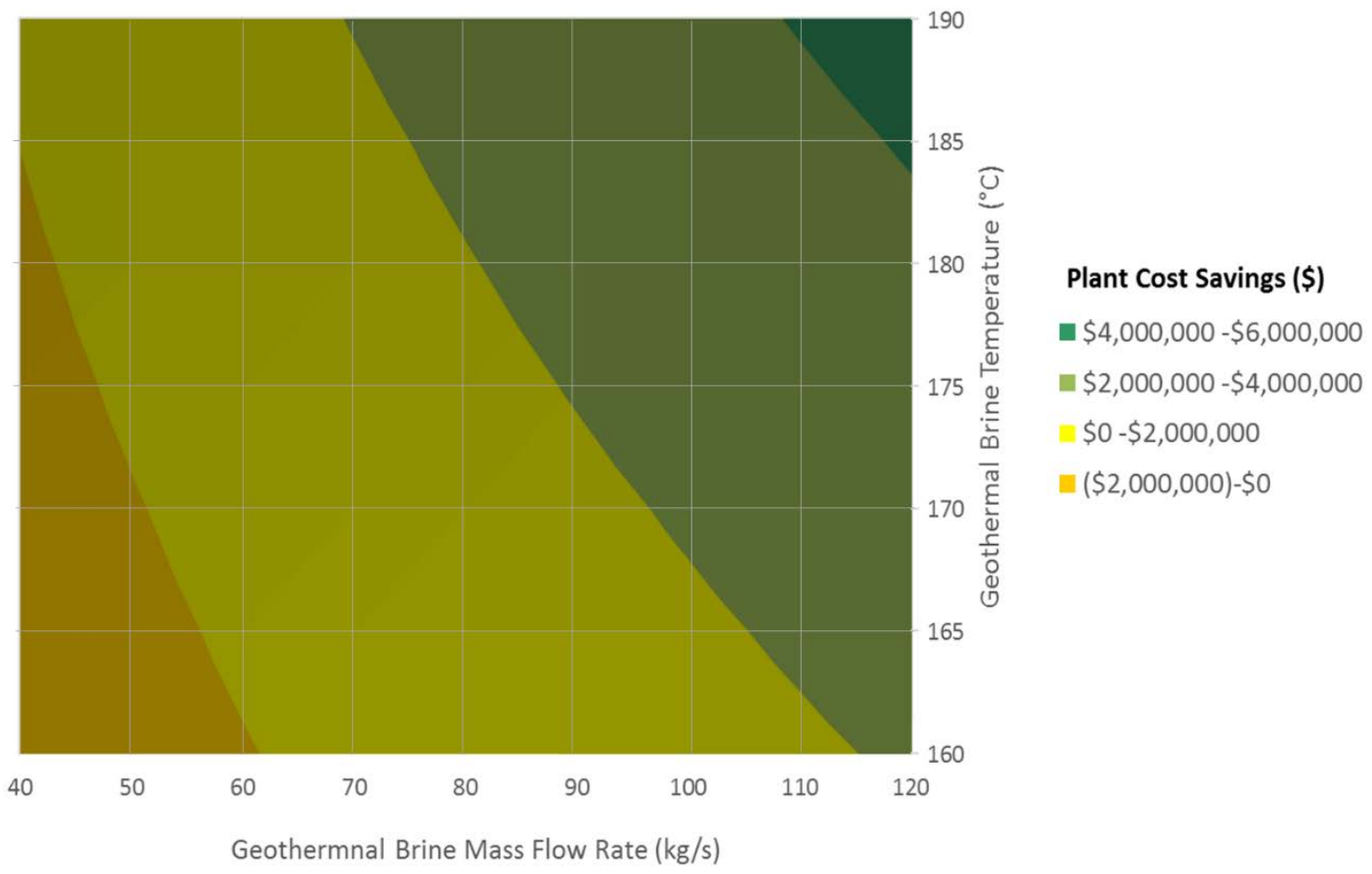

Figure 27 Plant cost savings (standard minus custom) as a function of geothermal brine temperature and flow rate 


\section{Discussions and Conclusions}

Currently, the geothermal turbine market is driven by developer demand for plant efficiency and consists of custom turbines designed specifically for the varying conditions encountered at different geothermal fields. Some degree of custom design may always be required. For example, geothermal steam turbines often require custom materials due to corrosion issues at different sites. However, the MSP analysis in this study showed that even applying a standard design to a relatively small number of units, as few as five, can have significant cost savings. The MSP calculations and sensitivity analysis for $1 \mathrm{MWe}$ and $5 \mathrm{MWe}$ turboexpanders and a $20 \mathrm{MWe}$ steam turbine showed that MSP could highly vary between $893 \$ / \mathrm{kW}$ and $30 \$ / \mathrm{kW}$ based on turbine size, standardization and volume of manufacturing. The analysis also showed that the economy of scale applies both to the size of the turbine and the number manufactured in a single run. As an example, the unit price of a $5 \mathrm{MW}$ standard design turbine could be $150 \$ / \mathrm{W}$ cheaper than the custom design. Sensitivity analysis showed that the main costs are associated with labor and D\&E for a custom designed unit. Manufacturing costs decrease significantly with volume due to shorter machine set up time, and D\&E is spread among multiple units. There is a significant opportunity for turbine manufacturers to realize manufacturing cost savings due to labor and D\&E by switching from custom to standard design at larger volumes. If manufacturers at all steps of the supply chain can successfully operate their facilities similar to the presented manufacturing model, it could result in up to $60 \%$ manufacturing cost savings. While the manufacturing cost model developed in this study is limited to the turbine component of a geothermal power plant, it can also be applied to other important components such as heat exchangers and air-cooled condensers.

In practice, a standard turbine design would likely operate at off-design conditions, resulting in lower efficiencies, less electricity generation, and less revenue than a custom turbine design. The second half of the study focused on determining whether and under what conditions the upfront capital cost savings from a standard turbine design could offset future revenue losses. To compare the economics of standard and custom turbine designs, we developed a model of a $5 \mathrm{MW}$ geothermal power plant project using a standard turbine design optimized to maximize power generation for a $175^{\circ} \mathrm{C}, 80 \mathrm{~kg} / \mathrm{s}$ geothermal resource. Then, we varied the geothermal resource over a range of temperatures and flow rates and compared power generation of the standard turbine operating at off-design conditions to a custom turbine operating a constant isentropic efficiency. We used these performance calculations and power output results in a DCF analysis of plant operations, costs and financing. The results of off-design performance analysis and financial calculations showed that NPV for lower efficiencies and decreased electricity generation from a standard turbine operating at off-design conditions could be higher than the NPV for a standard unit size to be undersized for a given resource versus a custom designed turbine. The results showed that the net capital cost savings from a standard design vs. a custom design turbine at the standard turbine design point for the modeled $5 \mathrm{MW}$ case study may reach up to $\$ 2.3$ million, while the difference in NPV could reach up to $\$ 1.4$ million. For this study, we did not have an accurate turbine performance curve to assess offdesign turbine performance. Instead, we used information relating turbine efficiency to working fluid flow rate to approximate off-design performance. The trends from that analysis 
show that standard turbine designs could be competitive over a wide range of temperatures and flow rates. A calculation of the standard turbine efficiencies at off-design conditions that give the same NPV as a project using a custom turbine showed that the range of off-design efficiencies support this conclusion.

The study shows that developing and using standard turbine designs may be an effective strategy for lowering geothermal power project costs. Ideally, these turbines would be designed to be flexible and operate over a wide range of conditions with minimal decreases in efficiency. The strategy requires that multiple turbines be built at once and then warehoused until sold. The study did not take into account the cost of financing and storing turbines until they are purchased for a project. A significant barrier to implementing this strategy is the demand for these technologies at high volumes. However, as the global geothermal market continues to grow, opportunities in new markets will continue to increase. The emerging geothermal markets discussed above show that there may be an opportunity for using standardized turbines to reduce plant capital costs. 


\section{References}

Bertani, R. (2016). "Geothermal Power Generation in the World 2010-2014 Update Report," Geothermics (60); pp. 31-43 https://doi.org/10.1016/i.geothermics.2015.11.003

BNEF, (2013), Q2 2013 Geothermal Market Outlook Report, Bloomberg New Energy Finance

BNEF, (2014), H2 2014 Geothermal Market Outlook Report, Bloomberg New Energy Finance

BNEF, (2015), H1 2015 Geothermal Market Outlook Report, Bloomberg New Energy Finance

BNEF, (2016), Geothermal Market Outlook Report, Bloomberg New Energy Finance

CEMAC, (2017), 'Minimum Sustainable Price: Understanding Sustainable Business Practices in Clean Energy Technology." Accessed May 5, 2017, http://www.manufacturingcleanenergy.org/blog20160510.html

Dewhurst B. Inc., (2016), DFA: Product Simplification and DFM: Concurrent Costing, http://www.dfma.com/software/dfma.htm, accessed 17th May 2017

Enerji Atlasi, (2018), Country Update for Turkey, http://www.enerjiatlasi.com/jeotermal/

Ellis P. F., Conover M. F., (1981), Material Selection Guidelines for Geothermal Energy Utilization Systems, Technical Report, DOE/RA/27026-1

Frost \& Sullivan, (2014), Global Gas and Steam Turbine Markets: Conventional Thermal Power Expansion Driven by Emerging Markets and Rising Natural Gas Availability. June 2014. M96C-14

Fuji Electric, 2012, CalEnergy Company, USA, Salton Sea Unit 5 Geothermal Power Plant Catalog GEA, (2015), Annual U.S. \& Global Geothermal Power Production Report, Geothermal Energy Agency GEA, (2016), Annual U.S. \& Global Geothermal Power Production Report, Geothermal Energy Agency GETEM, (2016), Geothermal Electricity Technology Evaluation Model, https://www.energy.gov/eere/geothermal/geothermal-electricity-technology-evaluation-model

Goodrich, A., Hacke P., Wang Q., Sopori B., Margolis R., James T. L., and Woodhouse M., (2013), A Wafer-Based Monocrystalline Silicon Photovoltaics Road Map: Utilizing Known Technology Improvement Opportunities for Further Reductions in Manufacturing Costs, Solar Energy Materials and Solar Cells, (vol. 114), pp.110-35. https://doi.org/10.1016/j.solmat.2013.01.030

Kaya T., Hoshan P., (2005), Corrosion and Material Selection for Geothermal Systems, Proceedings World Geothermal Congress 2005, Antalya, Turkey, 24-29 April 2005

Klocke F., Klink A., Veselovac D., Aspinwall D. K., Soo S. L., Schmidt M., Schilp J., Levy G., Kruth J., (2014), Turbomachinery component manufacture by application of electrochemical, electro-physical and photonic processes, CIRP Annals - Manufacturing Technology, (vol.63), pp. 706-728, http://dx.doi.org/10.1016/j.cirp.2014.05.004

Mendelsohn, M.; Kreycik, C.; Bird, L.; Schwabe, P.; Cory, K. (2012) The Impact of Financial Structure on the Cost of Solar Energy. National Renewable Energy Laboratory. NREL/TP-6A20-53086.

REN21, (2016), Renewables 2016 Global Status Report, http://www.ren21.net/status-ofrenewables/global-status-report/ 
Poernomo A., Satar S., Effendi P., Kusuma A., Azimudin T., Sudarwo S., (2015), An Overview of Indonesia Geothermal Development, Current Status and Its Challenges, Proceedings World Geothermal Congress 2015, Melbourne, Australia, 19-25 April 2015

Ross S.A., Westerfield R., Jordan B.D., (2009), Fundamentals of Corporate Finance, McGraw-Hill, Irwin, New York, NY.

Sandor D., Chung D., Keyser D., Mann M., Engel-Cox J., (2017), Benchmarks of Global Clean Energy Manufacturing, Clean Energy Manufacturing Analysis Center (CEMAC), (NREL/TP-6A50-65619) http://www.nrel.gov/docs/fy17osti/65619-ES.pdf

Short, W., Packey, D., Holt, T. (1995) A Manual for the Economic Evaluation of Energy Efficiency and Renewable Energy Technologies. National Renewable Energy Laboratory. NREL/TP-462-5173.

Tartière T., (2016), ORC Market: A World Overview, http://orc-world-map.org/index.html

TGE, (2017), Global Installed Geothermal Power Plants Update, Think GeoEnergy Research, http://www.thinkgeoenergy.com/

IEA, (2011), Turkish Renewable Energy Law 2010, Ministry of Energy and Natural Resources, https://www.iea.org/policiesandmeasures/pams/turkey/name-24961-en.php

Wall, A., Young, K., (2016), Doubling Geothermal Generation Capacity by 2020: A Strategic Analysis (NREL/TP - 6A20 - 64925), National Renewable Energy Laboratory, Golden, CO

http://www.nrel.gov/docs/fy16osti/64925.pdf 


\section{Appendix: List of Global Geothermal Power Plants}

\begin{tabular}{|c|c|c|c|c|c|c|c|}
\hline Country & Plant Name & Year & Capacity & Type & Project Developer/Owner/Operator & Turbine Manufacturer & $\begin{array}{l}\text { Manufacturing } \\
\text { Location }\end{array}$ \\
\hline Germany & Traunereut & 2015 & 5.5 & Binary & $\begin{array}{l}\text { Geothermischen Kraftwerksgesellschaft Traunreut } \mathrm{mbH} \\
\text { (GKT) }\end{array}$ & Turboden & Italy \\
\hline Japan & Oguni Matsuya & 2015 & 0.06 & Binary & N/A & Toshiba & Japan \\
\hline Japan & Tsuchiyu onsen & 2015 & 0.4 & Binary & Tsuchiyu Onsen Energy Co. & ORMAT & Israel \\
\hline Japan & Sugawara Binary Cycle & 2015 & 5.5 & Binary & Kyushu Electric Power & Turboden & Italy \\
\hline Turkey & Alasehir 1-2 & 2015 & 45 & Single Flash & ZORLU & Toshiba & Japan \\
\hline Turkey & Tosunlar & 2015 & 3.81 & Binary & Akca Holding & EXERGY & Italy \\
\hline Turkey & Umurlu 1-2 & 2015 & 12 & Binary & Karadeniz Holding & EXERGY & Italy \& Turkey \\
\hline Turkey & Pamukoren-2 & 2015 & 22.5 & Binary & Çelikler Jeotermal Elektrik & Atlas Copco, EXERGY & USA \\
\hline Turkey & Efe-2 & 2015 & 22.5 & Binary & GURIS & ORMAT & Israel \\
\hline Turkey & Efe-3 & 2015 & 22.5 & Binary & GURIS & ORMAT & Israel \\
\hline Turkey & Efe-4 & 2015 & 22.5 & Binary & GURIS & ORMAT & Israel \\
\hline Turkey & Babadere & 2015 & 8 & Binary & MTN Enerji & ORMAT & Israel \\
\hline USA & Don A. Campbell (Wild Rose) II & 2015 & 22.5 & Binary & ORMAT & ORMAT & Israel \\
\hline USA & McGinness Expansion & 2015 & 48 & Binary & ORMAT & ORMAT & Israel \\
\hline Kenya & Olkaria GEG (OW 914) & 2015 & 27.8 & Single Flash & Green Energy Group (GEG) & Hindustan Turbomacinery & India \\
\hline Kenya & Olkaria GEG (OW43) & 2015 & 12.8 & Single Flash & KenGen & Hindustan Turbomacinery & India \\
\hline Japan & Tsuchiyu onsen & 2015 & 0.4 & Binary & Tsuchiyu onsen energy Co. & ORMAT & Israel \\
\hline Mexico & Los Azufres III - 1 & 2015 & 53 & Single Flash & Comision Federal de Electricidad & Mitsubishi & Japan \\
\hline
\end{tabular}




\begin{tabular}{|c|c|c|c|c|c|c|c|}
\hline Country & Plant Name & Year & Capacity & Type & Project Developer/Owner/Operator & Turbine Manufacturer & $\begin{array}{l}\text { Manufacturing } \\
\text { Location }\end{array}$ \\
\hline USA & Paisley & 2014 & 2 & Binary & Surprise Valley Electric Co. & TAS & USA \\
\hline USA & OIT-2 & 2014 & 1.5 & Binary & OIT & Pratt \& Whitney & USA \\
\hline Kenya & Olkaria I unit-4 & 2014 & 70 & Single Flash & KenGen & Toyota Tsusho & Japan \\
\hline Kenya & Olkaria I unit-5 & 2014 & 70 & Single Flash & KenGen & Toyota Tsusho & Japan \\
\hline Kenya & Olkaria III & 2014 & 40 & Binary & ORMAT & ORMAT & Israel \\
\hline Kenya & Olkaria IV & 2014 & 70 & Single Flash & KenGen & Toyota Tsusho & Japan \\
\hline Kenya & Olkaria IV & 2014 & 70 & Single Flash & KenGen & Toyota Tsusho & Japan \\
\hline Turkey & Yilmazkoy (Ken Kipas) & 2014 & 24 & Binary & KIPAS & EXERGY & Italy \\
\hline Turkey & Alasehir & 2014 & 24 & Binary & Turkeler & ORMAT & Israel \\
\hline Turkey & Kerem & 2014 & 24 & Binary & MAREN & ORMAT & Israel \\
\hline Kenya & Olkaria3-Plant3 & 2014 & 24 & Binary & ORMAT & ORMAT & Israel \\
\hline Turkey & Kizildere-2 Binary & 2014 & 20 & Binary & ZORLU & TAS & USA \\
\hline Turkey & Dora3-U2 & 2014 & 17 & Binary & MENDERES & ORMAT & Israel \\
\hline Turkey & Gumuskoy-2 & 2014 & 6.6 & Binary & BM & TAS (repowerd by ORMAT) & USA \\
\hline Germany & $\begin{array}{l}\text { Oberhaching-Laufzorn / } \\
\text { Grünwald }\end{array}$ & 2014 & 4.3 & Binary & Daldrup \& Sohne AG (EGS) & Atlas Copco/Energas, GMK & Germany \\
\hline Japan & Hagenoyu & 2014 & 2 & Binary & $\begin{array}{l}\text { Keiyo Plant Engineering Co, Waita Geothermal Power } \\
\text { Plant, Chuo Electric Power Co }\end{array}$ & Toshiba & Japan \\
\hline Japan & Ibusuki & 2014 & 1.5 & Binary & Geonext Co. & ORMAT & Israel \\
\hline Japan & Beppu Spring & 2014 & 0.5 & Binary & N/A & Toshiba & Japan \\
\hline
\end{tabular}




\begin{tabular}{|c|c|c|c|c|c|c|c|}
\hline Country & Plant Name & Year & Capacity & Type & Project Developer/Owner/Operator & Turbine Manufacturer & $\begin{array}{l}\text { Manufacturing } \\
\text { Location }\end{array}$ \\
\hline Japan & Goto-en & 2014 & 0.09 & Binary & N/A & Toshiba & Japan \\
\hline Japan & Yumura Spring & 2014 & 0.03 & Binary & N/A & Kawasaki & Japan \\
\hline Japan & Shichimi Spring & 2014 & 0.02 & Binary & N/A & Kawasaki & Japan \\
\hline Kenya & Olkaria III & 2014 & 18 & Binary & N/A & ORMAT & Israel \\
\hline Kenya & Olkaria GEG (OW37) & 2014 & 5 & Single Flash & N/A & Hindustan Turbomacinery & India \\
\hline Germany & Taufkirchen/ Oberhaching & 2014 & 4 & Binary & N/A & Atlas Copco/Energas, GMK & Germany \\
\hline Germany & Sauerlach & 2014 & 5 & Binary & N/A & Turboden & Italy \\
\hline Turkey & Gümüsköy-1 & 2014 & 6.6 & Binary & BM & TAS (Repowerd by ORMAT) & USA \\
\hline Indonesia & Cibuni & 2014 & 2 & Single Flash & PLN & Elliot TurboMachinery & USA \\
\hline Indonesia & Ndunga & 2014 & 5 & Single Flash & PLN & Elliot TurboMachinery & USA \\
\hline Indonesia & Ulumbu & 2014 & 10 & Single Flash & PLN & Elliot TurboMachinery & USA \\
\hline Indonesia & Patuha Unit 1 & 2014 & 55 & Single Flash & PT. Geo Dipa Energy & Toshiba & Japan \\
\hline Italy & Bagnore 4 & 2014 & 40 & Single Flash & Enel Green Power & Ansaldo/Tosi & Italy \\
\hline Philippines & Nasulo & 2014 & 49.4 & Single Flash & Energy Development Corporation & Fuji & Japan \\
\hline USA & Patua & 2013 & 48 & Binary & Gradient Resources & TAS & USA \\
\hline USA & Lightening Dock & 2013 & 4.4 & Binary & Cyrq Energy & Kaishan & China \\
\hline USA & Don A. Campbell & 2013 & 22.5 & Binary & N/A & ORMAT & Israel \\
\hline USA & Cove Fort 1-2 & 2013 & 25 & Binary & N/A & ORMAT & Israel \\
\hline Nicaragua & San Jacinto-Tizate & 2013 & 36 & Single Flash & N/A & Fuji & Japan \\
\hline
\end{tabular}




\begin{tabular}{|c|c|c|c|c|c|c|c|}
\hline Country & Plant Name & Year & Capacity & Type & Project Developer/Owner/Operator & Turbine Manufacturer & $\begin{array}{l}\text { Manufacturing } \\
\text { Location }\end{array}$ \\
\hline Turkey & Efe-1 & 2013 & 47.4 & Double Flash & N/A & Mitsubishi & Japan \\
\hline Turkey & Kizildere-2 & 2013 & 60 & Double Flash & N/A & Fuji & Japan \\
\hline Germany & Durrhaar & 2013 & 7 & Binary & N/A & Turboden & Italy \\
\hline Turkey & Pamukören-1 & 2013 & 67.5 & Binary & Çelikler Jeotermal Elektrik & Atlas Copco, EXERGY & USA \\
\hline Turkey & Dora3-U1 & 2013 & 17 & Binary & MENDERES & ORMAT & Israel \\
\hline USA & Desert Peak (EGS) & 2013 & 1.7 & Binary & N/A & ORMAT & Israel \\
\hline Germany & Kirchstockach & 2013 & 7 & Binary & N/A & Turboden & Italy \\
\hline USA & Chena-2 & 2013 & 0.4 & Binary & N/A & Turboden & Italy \\
\hline Australia & Habanero-EGS & 2013 & 1 & Binary & N/A & Siemens & Germany \\
\hline Japan & Abo-tunnel & 2013 & 0.003 & Binary & N/A & Kawasaki & Japan \\
\hline USA & $\begin{array}{l}\text { Mammoth Complex } \\
\text { Repowering }\end{array}$ & 2013 & 7.5 & Binary & ORMAT & ORMAT & Israel \\
\hline Indonesia & Mataloko & 2013 & 2.5 & Single Flash & PLN & Elliot TurboMachinery & USA \\
\hline Mexico & Los Humeros II Phase 2 & 2013 & 26.7 & Single Flash & Comision Federal de Electricidad & Alstom & Mexico \\
\hline New Zealand & Ngatamariki & 2013 & 82 & Binary & Mighty River Power & ORMAT & Israel \\
\hline New Zealand & Te Mihi & 2013 & 166 & Double Flash & Contact Energy & Toshiba & Japan \\
\hline New Zealand & TOPP1 & 2013 & 25 & Binary & Nagati Tuwharetoa Geothermal & ORMAT & Israel \\
\hline Philippines & Maibarara & 2013 & 20 & Single Flash & $\begin{array}{l}\text { Maibarara Geothermal (JV PetroEnergy, Trans-Asia Oil, } \\
\text { and PNOC Renewables) }\end{array}$ & Fuji & Japan \\
\hline Nicaragua & San Jacinto-Tizate & 2012 & 36 & Single Flash & Ram Power & Fuji & Japan \\
\hline
\end{tabular}




\begin{tabular}{|c|c|c|c|c|c|c|c|}
\hline Country & Plant Name & Year & Capacity & Type & Project Developer/Owner/Operator & Turbine Manufacturer & $\begin{array}{l}\text { Manufacturing } \\
\text { Location }\end{array}$ \\
\hline USA & Hudson Ranch I & 2012 & 50 & Triple Flash & EnergySource & Fuji & Japan \\
\hline Germany & Dürrnhaar & 2012 & 5.5 & Binary & Municipality Germany & Turboden & Italy \\
\hline Germany & Insheim & 2012 & 4.3 & Binary & Municipality Germany & Turboden & Italy \\
\hline USA & McGinness Hill & 2012 & 48 & Binary & ORMAT & ORMAT & Israel \\
\hline USA & Tuscarora & 2012 & 24 & Binary & ORMAT & ORMAT & Israel \\
\hline Turkey & DENIZ & 2012 & 24 & Binary & MAREN & ORMAT & Israel \\
\hline Turkey & SINEM & 2012 & 24 & Binary & MAREN & ORMAT & Israel \\
\hline USA & Neal Hot Springs & 2012 & 33 & Binary & US Geothermal & TAS & USA \\
\hline USA & San Emidio & 2012 & 12 & Binary & US Geothermal & TAS & USA \\
\hline Germany & Sauerlach & 2012 & 5 & Binary & Municipality Germany & Turboden & Italy \\
\hline Japan & Niigata & 2012 & 2 & Binary & Wasabi & EcoGen & USA \\
\hline USA & Florida Canyon Mine & 2012 & 0.1 & Co-Production & Electratherm & Electratherm & USA \\
\hline Romania & Oradea & 2012 & 0.5 & Binary & Electratherm & Electratherm & USA \\
\hline Taiwan & Qingshui & 2012 & 0.1 & Binary & SSNE (Kalina Cycle) & Energent Turbine & USA \\
\hline China & YangYi-2 & 2012 & 0.4 & Binary & Jiangxi HuanDian Electric Co. & Jiangxi HuanDian Electric Co. & China \\
\hline Indonesia & Ulumbu & 2012 & 2.5 & Single Flash & Pertamina Geothermal Energy & Elliot TurboMachinery & USA \\
\hline Indonesia & Ulumbu & 2012 & 2.5 & Single Flash & Pertamina Geothermal Energy & Elliot TurboMachinery & USA \\
\hline Indonesia & Ulubelu Unit 1 & 2012 & 55 & Dry Steam & PLN & Fuji & Japan \\
\hline Indonesia & Ulubelu Unit 2 & 2012 & 55 & Dry Steam & PLN & Fuji & Japan \\
\hline
\end{tabular}




\begin{tabular}{|c|c|c|c|c|c|c|c|}
\hline Country & Plant Name & Year & Capacity & Type & Project Developer/Owner/Operator & Turbine Manufacturer & $\begin{array}{l}\text { Manufacturing } \\
\text { Location }\end{array}$ \\
\hline Italy & Bagnore 3 Binary & 2012 & 1 & Binary & Enel Green Power & Exergy & Italy \\
\hline Italy & Rancia 2 & 2012 & 20 & Dry Steam & Enel Green Power & Ansaldo/Tosi & Italy \\
\hline USA & Dixie Valley Binary & 2012 & 6.2 & Binary & Terra Gen & TAS & USA \\
\hline Mexico & Los Humeros & 2012 & 26.7 & Single Flash & Comision Federal de Electricidad & Alstom & Mexico \\
\hline China & Yangyi & 2011 & 0.9 & Single Flash & Jiangxi Huadian Electric & Jiangxi HuanDian Electric Co. & China \\
\hline Kenya & Eburru & 2011 & 2.5 & Single Flash & KenGen & Elliot Turbomachinery & USA \\
\hline Costa Rica & Las Pailas & 2011 & 21 & Binary & Instituto Costarricense de & ORMAT & Israel \\
\hline Costa Rica & Las Pailas & 2011 & 21 & Binary & Instituto Costarricense de & ORMAT & Israel \\
\hline Turkey & IREM & 2011 & 20 & Binary & MAREN & ORMAT & Israel \\
\hline USA & Puna Expansion & 2011 & 12 & Binary & ORMAT & ORMAT & Israel \\
\hline USA & Beowave-2 & 2011 & 3.6 & Binary & Beowawe Power Terra Gen & TAS & USA \\
\hline China & YangYi-1 & 2011 & 0.5 & Binary & Jiangxi HuanDian Electric Co. & Jiangxi HuanDian Electric Co. & China \\
\hline Indonesia & Lahendong Unit 4 & 2011 & 20 & Single Flash & Pertamina Geothermal Energy & Fuji & Japan \\
\hline Iceland & Hellisheidi 5 & 2011 & 45 & Single Flash & Orkuveita Reykjavikur & Mitsubishi & Japan \\
\hline Iceland & Hellisheidi 5 & 2011 & 45 & Single Flash & Orkuveita Reykjavikur & Mitsubishi & Japan \\
\hline Italy & Chiusdino 2 & 2011 & 20 & Dry Steam & Enel Green Power & Ansaldo/Tosi & Italy \\
\hline Italy & Nuova Radicondoli & 2011 & 20 & Dry Steam & Enel Green Power & General Electric- Nuovo Pignone & Italy \\
\hline Kenya & Olkaria II & 2010 & 35 & Single Flash & KenGen & Mitsubishi & Japan \\
\hline USA & Jersey Valley & 2010 & 22.5 & Binary & ORMAT & ORMAT & Israel \\
\hline
\end{tabular}




\begin{tabular}{|c|c|c|c|c|c|c|c|}
\hline Country & Plant Name & Year & Capacity & Type & Project Developer/Owner/Operator & Turbine Manufacturer & $\begin{array}{l}\text { Manufacturing } \\
\text { Location }\end{array}$ \\
\hline Turkey & Dora-2 & 2010 & 9.5 & Binary & MENDERES & ORMAT & Israel \\
\hline Turkey & Tuzla & 2010 & 7.5 & Binary & Dardanel & ORMAT & Israel \\
\hline China & Longyuan & 2010 & 1 & Binary & Longyuan Co & Longyuan Co & China \\
\hline China & North Oil Field (Huabei) & 2010 & 0.4 & Binary & Jiujiang Power & Jiujiang Power & China \\
\hline Italy & Chiusdino 1 & 2010 & 20 & Dry Steam & Enel Green Power & Ansaldo/Tosi & Italy \\
\hline Italy & Radicondoli 2 & 2010 & 20 & Dry Steam & Enel Green Power & Ansaldo/Tosi & Italy \\
\hline Kenya & Olkaria II & 2010 & 35 & Single Flash & KenGen & Mitsubishi & Japan \\
\hline New Zealand & Nga Awa Purua & 2010 & 139 & Triple Flash & Mighty River Power & Fuji & Japan \\
\hline New Zealand & Te Huka & 2010 & 23 & Binary & Top Energy & ORMAT & Israel \\
\hline Kenya & Olkaria III & 2009 & 52 & Binary & ORMAT (upgraded) & ORMAT & Israel \\
\hline Turkey & Germencik (Galip Hoca) & 2009 & 47.4 & Double Flash & GURMAT & Mitsubishi & Japan \\
\hline USA & OIT-1 & 2009 & 0.3 & Binary & OIT & Pratt \& Whitney & USA \\
\hline USA & Faulkner & 2009 & 63.9 & Binary & Nevada Geothermal & ORMAT & Israel \\
\hline USA & Stillwater & 2009 & 47.3 & Binary & Enel Green Power & Atlas Copco / Mafi-Trench & USA \\
\hline USA & Salt Wells & 2009 & 18.1 & Binary & Enel Green Power & Atlas Copco / Mafi-Trench & USA \\
\hline USA & Thermo Hot Spring & 2009 & 14 & Binary & Raser Technologies & Turboden & Italy \\
\hline Germany & Unterhaching & 2009 & 3.4 & Binary & Municipality (Kalina Cycle) & Siemens & Germany \\
\hline Germany & Bruchsal & 2009 & 0.55 & Binary & Municipality (Kalina Cycle) & Energent Turbine & USA \\
\hline Indonesia & Lahendong Unit 3 & 2009 & 20 & Single Flash & PLN & Fuji & Japan \\
\hline
\end{tabular}




\begin{tabular}{|c|c|c|c|c|c|c|c|}
\hline Country & Plant Name & Year & Capacity & Type & Project Developer/Owner/Operator & Turbine Manufacturer & $\begin{array}{l}\text { Manufacturing } \\
\text { Location }\end{array}$ \\
\hline Indonesia & Wayang Windu Unit 2 & 2009 & 117 & Single Flash & Star Energy Ltd & Fuji & Japan \\
\hline Italy & Nuova Lagoni Rossi & 2009 & 20 & Dry Steam & Enel Green Power & General Electric- Nuovo Pignone & Italy \\
\hline Italy & Sasso 2 & 2009 & 20 & Dry Steam & Enel Green Power & General Electric- Nuovo Pignone & Italy \\
\hline USA & North Brawley & 2008 & 50 & Binary & ORMAT & ORMAT & Israel \\
\hline USA & Galena III & 2008 & 30 & Binary & ORMAT & ORMAT & Israel \\
\hline USA & Raft River & 2008 & 18 & Binary & US Geot hermal & ORMAT & Israel \\
\hline El Salvador & Berlin & 2008 & 9.4 & Binary & LaGeo/Enel Green Power & Enex-GE-Rotoflow & USA \\
\hline Turkey & Kizildere Binary (Bereket) & 2008 & 6.8 & Binary & BEREKET & ORMAT & Israel \\
\hline France & Soultz-sous-Forêts & 2008 & 1.5 & Binary & European EGS Interest & Turboden & Italy \\
\hline USA & Heber South & 2008 & 16 & Binary & ORMAT & ORMAT & Israel \\
\hline Indonesia & Darajat & 2008 & 110 & Dry Steam & Chevron & Mitsubishi & Japan \\
\hline Indonesia & Lahendong Unit 2 & 2008 & 20 & Single Flash & PLN & Fuji & Japan \\
\hline Iceland & Hellisheidi 3 & 2008 & 45 & Single Flash & Orkuveita Reykjavikur & Mitsubishi & Japan \\
\hline Iceland & Hellisheidi 3 & 2008 & 45 & Single Flash & Orkuveita Reykjavikur & Mitsubishi & Japan \\
\hline New Zealand & Kawerau & 2008 & 95.72 & Double Flash & Mighty River Power & Fuji & Japan \\
\hline New Zealand & KA24 & 2008 & 8.3 & Binary & Savage Papakainga Trust & ORMAT & Israel \\
\hline New Zealand & Ngawha 2 & 2008 & 15 & Binary & Top Energy & ORMAT & Israel \\
\hline $\begin{array}{l}\text { Papua New } \\
\text { Guinea }\end{array}$ & Lihir & 2007 & 20 & Single Flash & Lihir Gold Ltd mine & General Electric & USA \\
\hline Nicaragua & San Jacinto-Tizate & 2007 & 10 & Back Pressure & Polaris & Alstom & France \\
\hline
\end{tabular}




\begin{tabular}{|c|c|c|c|c|c|c|c|}
\hline Country & Plant Name & Year & Capacity & Type & Project Developer/Owner/Operator & Turbine Manufacturer & $\begin{array}{l}\text { Manufacturing } \\
\text { Location }\end{array}$ \\
\hline Germany & Landau & 2007 & 3 & Binary & Municipality & ORMAT & Israel \\
\hline Guatemala & Amatitlán & 2007 & 24 & Binary & ORMAT & ORMAT & Israel \\
\hline USA & Galena II & 2007 & 13.5 & Binary & ORMAT & ORMAT & Israel \\
\hline USA & Blundell-2 & 2007 & 12 & Binary & Pacific Corporation & ORMAT & Israel \\
\hline USA & GEM Bottoming Cycle & 2007 & 9 & Binary & ORMAT & ORMAT & Israel \\
\hline Kenya & Oserian & 2007 & 2 & Binary & Oserian Flower co & Elliot Turbomachinery & USA \\
\hline USA & Steamboat Hills & 2007 & 5.5 & Binary & ORMAT & ORMAT & Israel \\
\hline USA & Ormesa II (Upgrade) & 2007 & 4.3 & Binary & ORMAT & ORMAT & Israel \\
\hline Indonesia & Kamojang Unit 4 & 2007 & 60 & Dry Steam & PLN & Fuji & Japan \\
\hline Indonesia & Sibayak & 2007 & 5.65 & Single Flash & Dizamatra Powerindo & Harbin & China \\
\hline Indonesia & Sibayak & 2007 & 5.65 & Single Flash & Dizamatra Powerindo & Harbin & China \\
\hline Iceland & Hellisheidi $2 \mathrm{~b}$ & 2007 & 33 & Single Flash & Orkuveita Reykjavikur & Toshiba & Japan \\
\hline Mexico & Los Humeros & 2007 & 5 & Back Pressure & Comision Federal de Electricidad & Mitsubishi & Japan \\
\hline New Zealand & Mokai 3 & 2007 & 17 & Binary & Tuaropaki Power Co. & ORMAT & Israel \\
\hline Russia & Mendeleevskaya & 2007 & 1.8 & Single Flash & SC Geotherm & Kaluga Turbine & Russia \\
\hline Russia & Okeanskaya & 2007 & 1.8 & Single Flash & SC Geotherm & Kaluga Turbine & Russia \\
\hline Russia & Okeanskaya & 2007 & 1.8 & Single Flash & SC Geotherm & Kaluga Turbine & Russia \\
\hline El Salvador & Berlin & 2006 & 44 & Single Flash & LaGeo/Enel Green Power & General Electric & USA \\
\hline USA & Desert Peak II (Brady Complex) & 2006 & 26 & Binary & ORMAT & ORMAT & Israel \\
\hline
\end{tabular}




\begin{tabular}{|c|c|c|c|c|c|c|c|}
\hline Country & Plant Name & Year & Capacity & Type & Project Developer/Owner/Operator & Turbine Manufacturer & $\begin{array}{l}\text { Manufacturing } \\
\text { Location }\end{array}$ \\
\hline Portugal & Pico Vermelho & 2006 & 13.5 & Binary & Electricidade dos Açores & ORMAT & Israel \\
\hline USA & Goulds-1 & 2006 & 10.5 & Binary & ORMAT & ORMAT & Israel \\
\hline Turkey & Dora-1 & 2006 & 7.9 & Binary & MENDERES & ORMAT & Israel \\
\hline Japan & Hatchobaru & 2006 & 2 & Binary & Kyushu Electric Power & ORMAT & Israel \\
\hline USA & Chena-1 & 2006 & 0.7 & Binary & Chena Hot Springs & Turboden & Italy \\
\hline Iceland & Hellisheidi 1 & 2006 & 45 & Single Flash & Orkuveita Reykjavikur & Mitsubishi & Japan \\
\hline Iceland & Hellisheidi 2a & 2006 & 45 & Single Flash & Orkuveita Reykjavikur & Mitsubishi & Japan \\
\hline Iceland & Reykjanes Unit 2 & 2006 & 50 & Single Flash & Hitaveita Sudurnesja \& HS Orka & Fuji & Japan \\
\hline Japan & Kirishima Geotherm & 2006 & 0.22 & Binary & Fuji & Fuji & Japan \\
\hline Japan & Suginoi & 2006 & 1.9 & Single Flash & Suginoi Hotel & Fuji & Japan \\
\hline $\begin{array}{l}\text { Papua New } \\
\text { Guinea }\end{array}$ & Lihir & 2005 & 30 & Single Flash & Lihir Gold Ltd mine & General Electric & USA \\
\hline USA & Goulds-2 & 2005 & 16 & Binary & ORMAT & ORMAT & Israel \\
\hline USA & Galena I (Richard Burdett) & 2005 & 30 & Binary & ORMAT & ORMAT & Israel \\
\hline Guadalope & Bouillante 2 & 2005 & 11 & Single Flash & ORMAT & Alstom & France \\
\hline Iceland & Nesjavellir & 2005 & 30 & Single Flash & Orkuveita Reykjavikur & Mitsubishi & Japan \\
\hline Iceland & Reykjanes Unit 1 & 2005 & 50 & Single Flash & Geothermie Bouilante & Fuji & Japan \\
\hline Iceland & Svartsengi Unit 6 & 2005 & 33 & Dry Steam & Hitaveita Sudurnesja \& HS Orka & Fuji & Japan \\
\hline Italy & Nuova Larderello & 2005 & 20 & Dry Steam & Enel Green Power & Ansaldo/Tosi & Italy \\
\hline Italy & Nuova San Martino & 2005 & 40 & Dry Steam & Enel Green Power & General Electric- Nuovo Pignone & Italy \\
\hline
\end{tabular}




\begin{tabular}{|c|c|c|c|c|c|c|c|}
\hline Country & Plant Name & Year & Capacity & Type & Project Developer/Owner/Operator & Turbine Manufacturer & $\begin{array}{l}\text { Manufacturing } \\
\text { Location }\end{array}$ \\
\hline New Zealand & Mokai 2 & 2005 & 19 & Binary & Tuaropaki Power Co. & ORMAT & Israel \\
\hline New Zealand & Mokai 2 & 2005 & 5 & Binary & Tuaropaki Power Co. & ORMAT & Israel \\
\hline New Zealand & Mokai 2 & 2005 & 5 & Binary & Tuaropaki Power Co. & ORMAT & Israel \\
\hline New Zealand & Mokai 2 & 2005 & 5 & Binary & Tuaropaki Power Co. & ORMAT & Israel \\
\hline New Zealand & Mokai 2 & 2005 & 5 & Binary & Tuaropaki Power Co. & ORMAT & Israel \\
\hline New Zealand & Wairakei Binary & 2005 & 14.4 & Binary & Contact Energy & ORMAT & Israel \\
\hline USA & Brady (Brady Complex) & 2004 & 5.3 & Binary & ORMAT & Ormat & Israel \\
\hline Kenya & Oserian & 2004 & 2 & Binary & Oserian Flower co & ORMAT & Israel \\
\hline New Zealand & Tasman BP & 2004 & 8 & Back Pressure & Norske Skog Tasman & Elliot TurboMachinery & USA \\
\hline Russia & Goryachii Plyazh & 2004 & 2.6 & Single Flash & SC Geotherm & Kaluga Turbine & Russia \\
\hline Russia & Mutnovskaya & 2004 & 50 & Single Flash & SC Geotherm & Kaluga Turbine & Russia \\
\hline Kenya & Olkaria II & 2003 & 35 & Single Flash & KenGen & Mitsubishi & Japan \\
\hline USA & Ormesa I (Ormesa Complex) & 2003 & 26.2 & Binary & ORMAT & Ormat & Israel \\
\hline Costa Rica & Miravalles 5 & 2003 & 17 & Binary & Instituto Costarricence de Electricidad & ORMAT & Israel \\
\hline Mexico & Los Azufres & 2003 & 26.5 & Single Flash & Comision Federal de Electricidad & Alstom & France \\
\hline Mexico & Los Azufres & 2003 & 26.5 & Single Flash & Comision Federal de Electricidad & Alstom & France \\
\hline Mexico & Los Azufres & 2003 & 26.5 & Single Flash & Comision Federal de Electricidad & Alstom & France \\
\hline Mexico & Los Azufres & 2003 & 26.5 & Single Flash & Comision Federal de Electricidad & Alstom & France \\
\hline Mexico & Los Humeros & 2003 & 5 & Back Pressure & Comision Federal de Electricidad & Ansaldo/Tosi & Italy \\
\hline
\end{tabular}




\begin{tabular}{|c|c|c|c|c|c|c|c|}
\hline Country & Plant Name & Year & Capacity & Type & Project Developer/Owner/Operator & Turbine Manufacturer & $\begin{array}{l}\text { Manufacturing } \\
\text { Location }\end{array}$ \\
\hline New Zealand & Rotokawa & 2003 & 6 & Binary & Mighty River Power & ORMAT & Israel \\
\hline Indonesia & Lahendong Unit 1 & 2002 & 20 & Single Flash & PLN & Alstom & France \\
\hline Austria & Altheim & 2002 & 1 & Binary & Marktgemeinde Altheim GmbH & Turboden & Italy \\
\hline Italy & Nuova Gabbro & 2002 & 20 & Dry Steam & Enel Green Power & General Electric- Nuovo Pignone & Italy \\
\hline Italy & Nuova Lago & 2002 & 10 & Dry Steam & Enel Green Power & General Electric- Nuovo Pignone & Italy \\
\hline Italy & Nuova Molinetto & 2002 & 20 & Dry Steam & Enel Green Power & General Electric- Nuovo Pignone & Italy \\
\hline Italy & Nuova Monterotondo & 2002 & 10 & Dry Steam & Enel Green Power & General Electric- Nuovo Pignone & Italy \\
\hline Italy & Nuova Radicondoli & 2002 & 40 & Dry Steam & Enel Green Power & General Electric- Nuovo Pignone & Italy \\
\hline Italy & Nuova Serrazzano & 2002 & 60 & Dry Steam & Enel Green Power & Ansaldo/Tosi & Italy \\
\hline Italy & Sesta & 2002 & 20 & Dry Steam & Enel Green Power & Ansaldo/Tosi & Italy \\
\hline Italy & Travale 4 & 2002 & 40 & Dry Steam & Enel Green Power & Ansaldo/Tosi & Italy \\
\hline Mexico & Las Tres Virgenes & 2002 & 5 & Single Flash & Comision Federal de Electricidad & Alstom & France \\
\hline Mexico & Las Tres Virgenes & 2002 & 5 & Single Flash & Comision Federal de Electricidad & Alstom & France \\
\hline Mexico & Las Tres Virgenes & 2002 & 2 & Binary & Comision Federal de Electricidad & ORMAT & Israel \\
\hline Austria & Blumau & 2001 & 0.2 & Binary & Municipality & Ormat & Israel \\
\hline Iceland & Nesjavellir & 2001 & 30 & Single Flash & Orkuveita Reykjavikur & Mitsubishi & Japan \\
\hline $\begin{array}{l}\text { Papua New } \\
\text { Guinea }\end{array}$ & Lihir & 2001 & 6 & Single Flash & Lihir Gold Ltd mine & General Electric & USA \\
\hline USA & CE Turbo & 2000 & 11.5 & Single Flash & CalEnergy Generation & Fuji & Japan \\
\hline USA & Salton Sea V & 2000 & 58.32 & Double Flash & CalEnergy Generation & Fuji & Japan \\
\hline
\end{tabular}




\begin{tabular}{|c|c|c|c|c|c|c|c|}
\hline Country & Plant Name & Year & Capacity & Type & Project Developer/Owner/Operator & Turbine Manufacturer & $\begin{array}{l}\text { Manufacturing } \\
\text { Location }\end{array}$ \\
\hline Indonesia & Wayang Windu Unit 1 & 2000 & 110 & Single Flash & Star Energy Ltd & Fuji & Japan \\
\hline Costa Rica & Miravalles 3 & 2000 & 29.5 & Single Flash & Instituto Costarricence de Electricidad & Mitsubishi & Japan \\
\hline Iceland & Husavik Kalina & 2000 & 2 & Binary & Orkuveita Husavikur & Enex-GE-Rotoflow & USA \\
\hline Italy & Nuova Castelnuovo & 2000 & 14.5 & Dry Steam & Enel Green Power & Ansaldo/Tosi & Italy \\
\hline Italy & Travale 3 & 2000 & 20 & Dry Steam & Enel Green Power & Ansaldo/Tosi & Italy \\
\hline Japan & Kuju & 2000 & 0.99 & Single Flash & Kuju Kanko Hotel & Kawasaki & Japan \\
\hline Mexico & Cerro Prieto 4 & 2000 & 25 & Single Flash & Comision Federal de Electricidad & Mitsubishi & Japan \\
\hline Mexico & Cerro Prieto 4 & 2000 & 25 & Single Flash & Comision Federal de Electricidad & Mitsubishi & Japan \\
\hline Mexico & Cerro Prieto 4 & 2000 & 25 & Single Flash & Comision Federal de Electricidad & Mitsubishi & Japan \\
\hline Mexico & Cerro Prieto 4 & 2000 & 25 & Single Flash & Comision Federal de Electricidad & Mitsubishi & Japan \\
\hline Russia & Pauzhetskaya & 2000 & 11 & Single Flash & SC Geotherm & Kaluga Turbine & Russia \\
\hline Russia & Verkhne-Mutnovskaya & 2000 & 4 & Single Flash & SC Geotherm & Kaluga Turbine & Russia \\
\hline Indonesia & Darajat & 1999 & 95 & Dry Steam & Chevron & Mitsubishi & Japan \\
\hline El Salvador & Berlin I Unit 1 & 1999 & 28.12 & Single Flash & LaGeo & Fuji & Japan \\
\hline El Salvador & Berlin I Unit 2 & 1999 & 28.12 & Single Flash & LaGeo & Fuji & Japan \\
\hline Ethiophia & Aluto-Langano 1-2 & 1999 & 7.5 & Binary & Ethiopian Electric Power Corporation & ORMAT & Israel \\
\hline Guatemala & Zunil & 1999 & 24 & Binary & ORMAT & ORMAT & Israel \\
\hline Guadalope & Bouillante 1 & 1999 & 4 & Double Flash & ORMAT & Alstom & France \\
\hline Iceland & Svartsengi Unit 5 & 1999 & 30 & Single Flash & Hitaveita Sudurnesja \& HS Orka & Fuji & Japan \\
\hline
\end{tabular}




\begin{tabular}{|c|c|c|c|c|c|c|c|}
\hline Country & Plant Name & Year & Capacity & Type & Project Developer/Owner/Operator & Turbine Manufacturer & $\begin{array}{l}\text { Manufacturing } \\
\text { Location }\end{array}$ \\
\hline Japan & Hachijojima & 1999 & 3.3 & Single Flash & Tokyo Electric Power & Fuji & Japan \\
\hline New Zealand & Mokai 1 & 1999 & 5 & Binary & Tuaropaki Power Co. & ORMAT & Israel \\
\hline New Zealand & Mokai 1 & 1999 & 5 & Binary & Tuaropaki Power Co. & ORMAT & Israel \\
\hline New Zealand & Mokai 1 & 1999 & 5 & Binary & Tuaropaki Power Co. & ORMAT & Israel \\
\hline New Zealand & Mokai 1 & 1999 & 5 & Binary & Tuaropaki Power Co. & ORMAT & Israel \\
\hline New Zealand & Mokai 1 & 1999 & 5 & Binary & Tuaropaki Power Co. & ORMAT & Israel \\
\hline New Zealand & Mokai 1 & 1999 & 30 & Single Flash & Tuaropaki Power Co. & ORMAT & Israel \\
\hline Nicaragua & Momotombo & 1999 & 22 & Single Flash & Momotombo Power Group & Ansaldo/Tosi & Italy \\
\hline Philippines & Mindanao 2 & 1999 & 52.4 & Double Flash & FDC Misamis & Mitsubishi & Japan \\
\hline Russia & Verkhne-Mutnovskaya & 1999 & 4 & Single Flash & SC Geotherm & Kaluga Turbine & Russia \\
\hline Indonesia & Dieng & 1998 & 60 & Single Flash & PT. Geo Dipa Energy & Ansaldo/Tosi & Italy \\
\hline Costa Rica & Miravalles 2 & 1998 & 55 & Single Flash & Instituto Costarricence de Electricidad & Ansaldo/Tosi & Italy \\
\hline Iceland & Nesjavellir & 1998 & 30 & Single Flash & Orkuveita Reykjavikur & Mitsubishi & Japan \\
\hline Iceland & Nesjavellir & 1998 & 30 & Single Flash & Orkuveita Reykjavikur & Mitsubishi & Japan \\
\hline Italy & Bagnore 3 & 1998 & 20 & Single Flash & Enel Green Power & Ansaldo/Tosi & Italy \\
\hline Italy & Carboli 1 & 1998 & 20 & Dry Steam & Enel Green Power & Ansaldo/Tosi & Italy \\
\hline New Zealand & Ngawha & 1998 & 5 & Binary & Top Energy & ORMAT & Israel \\
\hline New Zealand & Ngawha & 1998 & 5 & Binary & Top Energy & ORMAT & Israel \\
\hline Philippines & Bacman LowLoad & 1998 & 1.5 & Single Flash & National Power Corporation & Mitsubishi & Japan \\
\hline
\end{tabular}




\begin{tabular}{|c|c|c|c|c|c|c|c|}
\hline Country & Plant Name & Year & Capacity & Type & Project Developer/Owner/Operator & Turbine Manufacturer & $\begin{array}{l}\text { Manufacturing } \\
\text { Location }\end{array}$ \\
\hline Russia & Verkhne-Mutnovskaya & 1998 & 4 & Single Flash & SC Geotherm & Kaluga Turbine & Russia \\
\hline Indonesia & Gunung Salak & 1997 & 60 & Single Flash & PLN & Fuji & Japan \\
\hline Indonesia & Gunung Salak-IPP Unit 4 & 1997 & 55 & Single Flash & Chevron & Fuji & Japan \\
\hline Indonesia & Gunung Salak-IPP Unit 5 & 1997 & 55 & Single Flash & Chevron & Fuji & Japan \\
\hline Indonesia & Gunung Salak-IPP Unit 6 & 1997 & 55 & Single Flash & Chevron & Fuji & Japan \\
\hline Iceland & Krafla & 1997 & 30 & Double Flash & Geothermie Bouilante & Mitsubishi & Japan \\
\hline Italy & Carboli 2 & 1997 & 20 & Dry Steam & Enel Green Power & Ansaldo/Tosi & Italy \\
\hline Italy & Monteverdi 1 & 1997 & 20 & Dry Steam & Enel Green Power & Ansaldo/Tosi & Italy \\
\hline Italy & Monteverdi 2 & 1997 & 20 & Dry Steam & Enel Green Power & Ansaldo/Tosi & Italy \\
\hline Italy & Selva & 1997 & 20 & Dry Steam & Enel Green Power & Ansaldo/Tosi & Italy \\
\hline New Zealand & Rotokawa & 1997 & 14 & Single Flash & Mighty River Power & General Electric & USA \\
\hline Philippines & Mahanagdong A-Binary & 1997 & 6.5 & Binary & Energy Development Corporation & Ormat & Israel \\
\hline Philippines & Mahanagdong A-Binary & 1997 & 6.5 & Binary & Energy Development Corporation & Ormat & Israel \\
\hline Philippines & Mahanagdong B-Binary & 1997 & 6.5 & Binary & Energy Development Corporation & Ormat & Israel \\
\hline Philippines & Mahanagdong B-Binary & 1997 & 6.5 & Binary & Energy Development Corporation & Ormat & Israel \\
\hline Philippines & Malitbong \Bottoming Binary & 1997 & 16.7 & Binary & Energy Development Corporation & ORMAT & Israel \\
\hline Philippines & Tongonan 1 - Binary & 1997 & 6.5 & Binary & Energy Development Corporation & Ormat & Israel \\
\hline Philippines & Tongonan 1 - Binary & 1997 & 6.5 & Binary & Energy Development Corporation & Ormat & Israel \\
\hline Philippines & Tongonan 1 - Binary & 1997 & 6.5 & Binary & Energy Development Corporation & Ormat & Israel \\
\hline
\end{tabular}




\begin{tabular}{|c|c|c|c|c|c|c|c|}
\hline Country & Plant Name & Year & Capacity & Type & Project Developer/Owner/Operator & Turbine Manufacturer & $\begin{array}{l}\text { Manufacturing } \\
\text { Location }\end{array}$ \\
\hline Philippines & Mahanagdong A & 1997 & 60 & Single Flash & Energy Development Corporation & Toshiba & Japan \\
\hline Philippines & Mahanagdong A & 1997 & 60 & Single Flash & Energy Development Corporation & Toshiba & Japan \\
\hline Philippines & Mahanagdong B & 1997 & 60 & Single Flash & Energy Development Corporation & Toshiba & Japan \\
\hline Philippines & Malitbong Unit 1 & 1997 & 77.5 & Single Flash & Energy Development Corporation & Fuji & Japan \\
\hline Philippines & Malitbong Unit 2 & 1997 & 77.5 & Single Flash & Energy Development Corporation & Fuji & Japan \\
\hline Philippines & Malitbong Unit 3 & 1997 & 77.5 & Single Flash & Energy Development Corporation & Fuji & Japan \\
\hline Indonesia & Sibayak & 1996 & 2 & Back Pressure & Pertamina Geothermal Energy & Kawasaki & Japan \\
\hline Italy & Le Prata & 1996 & 20 & Dry Steam & Enel Green Power & Ansaldo/Tosi & Italy \\
\hline Italy & Nuova Sasso & 1996 & 20 & Dry Steam & Enel Green Power & Ansaldo/Tosi & Italy \\
\hline Japan & Takigami & 1996 & 27.5 & Single Flash & Kyushu Electric Power & Mitsubishi & Japan \\
\hline Japan & Kakkonda & 1996 & 30 & Single Flash & Tohoku Electric Power & Toshiba & Japan \\
\hline Japan & Ogiri & 1996 & 30 & Single Flash & Kyushu Electric Power & Mitsubishi & Japan \\
\hline USA & Salton Sea IV & 1996 & 51 & Double Flash & CalEnergy Generation & General Electric & USA \\
\hline New Zealand & Poihipi & 1996 & 55 & Dry Steam & Contact Energy & Fuji & Japan \\
\hline Philippines & Upper Mahiao-1 & 1996 & 34.12 & Binary & Energy Development Corporation & Ormat & Israel \\
\hline Philippines & Upper Mahiao-2 & 1996 & 34.12 & Binary & Energy Development Corporation & Ormat & Israel \\
\hline Philippines & Upper Mahiao-3 & 1996 & 34.12 & Binary & Energy Development Corporation & Ormat & Israel \\
\hline Philippines & Upper Mahiao-4 & 1996 & 34.12 & Binary & Energy Development Corporation & Ormat & Israel \\
\hline Philippines & Upper Mahiao Binary & 1996 & 5.5 & Binary & Energy Development Corporation & Ormat & Israel \\
\hline
\end{tabular}




\begin{tabular}{|c|c|c|c|c|c|c|c|}
\hline Country & Plant Name & Year & Capacity & Type & Project Developer/Owner/Operator & Turbine Manufacturer & $\begin{array}{l}\text { Manufacturing } \\
\text { Location }\end{array}$ \\
\hline Costa Rica & Miravalles Boca de pozo & 1995 & 5 & Single Flash & Instituto Costarricence de Electricidad & Mitsubishi & Japan \\
\hline Italy & Farinello & 1995 & 60 & Dry Steam & Enel Green Power & Ansaldo/Tosi & Italy \\
\hline Japan & Yamakawa & 1995 & 30 & Single Flash & Kyushu Electric Power & Mitsubishi & Japan \\
\hline Japan & Sumikawa & 1995 & 50 & Single Flash & Tohoku Electric Power & Mitsubishi & Japan \\
\hline Japan & Yanaizu-Nishiyama & 1995 & 65 & Single Flash & Tohoku Electric Power & Toshiba & Japan \\
\hline Philippines & Mak-Ban D & 1995 & 20 & Single Flash & Aboitiz Power Corp & Mitsubishi & Japan \\
\hline Philippines & Mak-Ban D & 1995 & 20 & Single Flash & Aboitiz Power Corp & Mitsubishi & Japan \\
\hline Philippines & Mak-Ban E & 1995 & 20 & Single Flash & Aboitiz Power Corp & Mitsubishi & Japan \\
\hline Philippines & Mak-Ban E & 1995 & 20 & Single Flash & Aboitiz Power Corp & Mitsubishi & Japan \\
\hline Philippines & Mindanao 1 & 1995 & 52.4 & Single Flash & FDC Misamis & Mitsubishi & Japan \\
\hline Indonesia & Darajat & 1994 & 55 & Dry Steam & Chevron & Mitsubishi & Japan \\
\hline Indonesia & Gunung Salak & 1994 & 60 & Single Flash & PLN & Ansaldo/Tosi & Italy \\
\hline Indonesia & Gunung Salak & 1994 & 60 & Single Flash & PLN & Ansaldo/Tosi & Italy \\
\hline Costa Rica & Miravalles 1 & 1994 & 55 & Single Flash & Instituto Costarricence de Electricidad & Toshiba & Japan \\
\hline Italy & Cornia 2 & 1994 & 20 & Dry Steam & Enel Green Power & Ansaldo/Tosi & Italy \\
\hline Italy & Piancastagnaio 5 & 1994 & 20 & Dry Steam & Enel Green Power & Ansaldo/Tosi & Italy \\
\hline Japan & Uenotai & 1994 & 28.8 & Single Flash & Tohoku Electric Power & Toshiba & Japan \\
\hline Mexico & Los Humeros & 1994 & 5 & Back Pressure & Comision Federal de Electricidad & Ansaldo/Tosi & Italy \\
\hline Philippines & Mak-Ban Binary1 & 1994 & 3 & Binary & Aboitiz Power Corp & Ormat & Israel \\
\hline
\end{tabular}




\begin{tabular}{|c|c|c|c|c|c|c|c|}
\hline Country & Plant Name & Year & Capacity & Type & Project Developer/Owner/Operator & Turbine Manufacturer & $\begin{array}{l}\text { Manufacturing } \\
\text { Location }\end{array}$ \\
\hline Philippines & Mak-Ban Binary1 & 1994 & 3 & Binary & Aboitiz Power Corp & Ormat & Israel \\
\hline Philippines & Mak-Ban Binary2 & 1994 & 3 & Binary & Aboitiz Power Corp & Ormat & Israel \\
\hline Philippines & Mak-Ban Binary2 & 1994 & 3 & Binary & Aboitiz Power Corp & Ormat & Israel \\
\hline Philippines & Mak-Ban Binary3 & 1994 & 3 & Binary & Aboitiz Power Corp & Ormat & Israel \\
\hline Philippines & Mak-Ban Binary3 & 1994 & 0.75 & Binary & Aboitiz Power Corp & Ormat & Israel \\
\hline Philippines & Bacman 2 (Cawayan) & 1994 & 20 & Single Flash & National Power Corporation & Mitsubishi & Japan \\
\hline Philippines & Palimpinon 2 (Sogongon) & 1994 & 20 & Single Flash & National Power Corporation & Fuji & Japan \\
\hline Philippines & Palimpinon 2 (Sogongon) & 1994 & 20 & Single Flash & National Power Corporation & Fuji & Japan \\
\hline Philippines & Palimpinon 2 Unit 2 (Nasuji) & 1994 & 20 & Single Flash & National Power Corporation & Fuji & Japan \\
\hline Portugal & Ribeira Grande & 1994 & 15 & Binary & Electricidade dos Açores & ORMAT & Israel \\
\hline USA & $\begin{array}{l}\text { Heber II (Heber Complex) } \\
\text { Second Imperial }\end{array}$ & 1993 & 48 & Binary & Ormat & Ormat & Israel \\
\hline Philippines & Bacman 1 & 1993 & 60 & Single Flash & National Power Corporation & Ansaldo/Tosi & Italy \\
\hline Philippines & Bacman 1 & 1993 & 60 & Single Flash & National Power Corporation & Ansaldo/Tosi & Italy \\
\hline Philippines & Palimpinon 2 Unit 1 (Okoy) & 1993 & 20 & Single Flash & National Power Corporation & Fuji & Japan \\
\hline China & Yangbajian North Unit-4 & 1992 & 3 & Double Flash & Electric Power Tibet & Qingdao Jieneng & China \\
\hline USA & $\begin{array}{l}\text { Brady Hot Spring (Brady } \\
\text { Complex) }\end{array}$ & 1992 & 26.1 & Double Flash & Ormat & ORMAT & Israel \\
\hline USA & Puna & 1992 & 35 & Binary & Ormat & Ormat & Israel \\
\hline USA & $\begin{array}{l}\text { Steamboat } 2 \text { (Steamboat } \\
\text { Complex) }\end{array}$ & 1992 & 18.2 & Binary & Ormat & Ben Holt & USA \\
\hline
\end{tabular}




\begin{tabular}{|c|c|c|c|c|c|c|c|}
\hline Country & Plant Name & Year & Capacity & Type & Project Developer/Owner/Operator & Turbine Manufacturer & $\begin{array}{l}\text { Manufacturing } \\
\text { Location }\end{array}$ \\
\hline USA & $\begin{array}{l}\text { Steamboat } 3 \text { (Steamboat } \\
\text { Complex) }\end{array}$ & 1992 & 18.2 & Binary & Ormat & Ben Holt & USA \\
\hline Mexico & Los Azufres & 1992 & 5 & Back Pressure & Comision Federal de Electricidad & Ansaldo/Makrotek & Italy \\
\hline Mexico & Los Humeros & 1992 & 5 & Back Pressure & Comision Federal de Electricidad & Ansaldo/Tosi & Italy \\
\hline China & Yangbajian North Unit-3 & 1991 & 3 & Double Flash & Electric Power Tibet & Qingdao Jieneng & China \\
\hline Italy & Piancastagnaio 4 & 1991 & 20 & Dry Steam & Enel Green Power & Ansaldo/Tosi & Italy \\
\hline Italy & Valle Secolo & 1991 & 60 & Dry Steam & Enel Green Power & Ansaldo/Tosi & Italy \\
\hline Italy & Valle Secolo & 1991 & 60 & Dry Steam & Enel Green Power & Ansaldo/Tosi & Italy \\
\hline USA & Soda Lake 2 & 1991 & 18 & Binary & Cyrq Energy & Ormat & Israel \\
\hline Mexico & Los Humeros & 1991 & 5 & Back Pressure & Comision Federal de Electricidad & Ansaldo/Tosi & Italy \\
\hline Mexico & Los Humeros & 1991 & 5 & Back Pressure & Comision Federal de Electricidad & Ansaldo/Tosi & Italy \\
\hline Italy & Piancastagnaio 3 & 1990 & 20 & Dry Steam & Enel Green Power & Ansaldo/Tosi & Italy \\
\hline Japan & Hatchobaru Unit 2 & 1990 & 55 & Double Flash & Kyushu Electric Power & Mitsubishi & Japan \\
\hline USA & $\begin{array}{l}\text { Mammoth II (Mammoth } \\
\text { Complex) }\end{array}$ & 1990 & 40 & Binary & Ormat & Ben Holt & USA \\
\hline USA & Leathers & 1990 & 35.8 & Double Flash & CalEnergy Generation & Fuji & Japan \\
\hline USA & Salton Sea II & 1990 & 20 & Double Flash & CalEnergy Generation & Mitsubishi & Japan \\
\hline Mexico & Los Azufres & 1990 & 5 & Back Pressure & Comision Federal de Electricidad & Ansaldo/Tosi & Japan \\
\hline Mexico & Los Humeros & 1990 & 5 & Back Pressure & Comision Federal de Electricidad & Ansaldo/Tosi & Italy \\
\hline Mexico & Los Humeros & 1990 & 5 & Back Pressure & Comision Federal de Electricidad & Ansaldo/Tosi & Italy \\
\hline
\end{tabular}




\begin{tabular}{|c|c|c|c|c|c|c|c|}
\hline Country & Plant Name & Year & Capacity & Type & Project Developer/Owner/Operator & Turbine Manufacturer & $\begin{array}{l}\text { Manufacturing } \\
\text { Location }\end{array}$ \\
\hline China & Yangbajian North Unit-2 & 1989 & 3 & Double Flash & Electric Power Tibet & Qingdao Jieneng & China \\
\hline Iceland & Svartsengi Binary & 1989 & 1.2 & Binary & Hitaveita Sudurnesja \& HS Orka & ORMAT & Israel \\
\hline Iceland & Svartsengi Binary & 1989 & 1.2 & Binary & Hitaveita Sudurnesja \& HS Orka & ORMAT & Israel \\
\hline Iceland & Svartsengi Binary & 1989 & 1.2 & Binary & Hitaveita Sudurnesja \& HS Orka & ORMAT & Israel \\
\hline Iceland & Svartsengi Binary & 1989 & 1.2 & Binary & Hitaveita Sudurnesja \& HS Orka & ORMAT & Israel \\
\hline Iceland & Svartsengi Binary & 1989 & 1.2 & Binary & Hitaveita Sudurnesja \& HS Orka & ORMAT & Israel \\
\hline Iceland & Svartsengi Binary & 1989 & 1.2 & Binary & Hitaveita Sudurnesja \& HS Orka & ORMAT & Israel \\
\hline Iceland & Svartsengi Binary & 1989 & 1.2 & Binary & Hitaveita Sudurnesja \& HS Orka & ORMAT & Israel \\
\hline Japan & Takenaka Corp. & 1989 & 0.045 & Single Flash & Takenaka Corp. & Fuji & Japan \\
\hline USA & Aidlin Unit 1 & 1989 & 12.5 & Dry Steam & Calpine & Fuji & Japan \\
\hline USA & Aidlin Unit 2 & 1989 & 12.5 & Dry Steam & Calpine & Fuji & Japan \\
\hline USA & Honey Lake & 1989 & 1.5 & Binary & HL Power Company & General Electric & USA \\
\hline USA & Del Ranch (Hoch) & 1989 & 35.8 & Double Flash & CalEnergy Generation & Fuji & Japan \\
\hline USA & Elmore & 1989 & 35.8 & Double Flash & CalEnergy Generation & Fuji & Japan \\
\hline USA & GEM II (Ormesia Complex) & 1989 & 21.6 & Double Flash & Ormat & Mitsubishi & Japan \\
\hline USA & GEM III (Ormesia Complex) & 1989 & 21.6 & Double Flash & Ormat & Mitsubishi & Japan \\
\hline USA & Navy II Unit 1 & 1989 & 30 & Double Flash & Terra Gen & Fuji & Japan \\
\hline USA & Navy II Unit 2 & 1989 & 30 & Double Flash & Terra Gen & Fuji & Japan \\
\hline USA & Navy II Unit 3 & 1989 & 30 & Double Flash & Terra Gen & Fuji & Japan \\
\hline
\end{tabular}




\begin{tabular}{|c|c|c|c|c|c|c|c|}
\hline Country & Plant Name & Year & Capacity & Type & Project Developer/Owner/Operator & Turbine Manufacturer & $\begin{array}{l}\text { Manufacturing } \\
\text { Location }\end{array}$ \\
\hline USA & Salton Sea III & 1989 & 54 & Double Flash & CalEnergy Generation & Mitsubishi & Japan \\
\hline New Zealand & Ohaaki & 1989 & 46 & Single Flash & Contact Energy & Mitsubishi & Japan \\
\hline New Zealand & Ohaaki & 1989 & 11.2 & Back Pressure & Contact Energy & Mitsubishi & Japan \\
\hline New Zealand & Ohaaki & 1989 & 11.2 & Back Pressure & Contact Energy & General Electric & USA \\
\hline Thailand & Fang & 1989 & 0.3 & Binary & Electricity Generating Authority of Thailand & ORMAT & Israel \\
\hline China & Yangbajian North Unit-1 & 1988 & 3 & Double Flash & Electric Power Tibet & Qingdao Jieneng & China \\
\hline USA & Amedee (Wendel) & 1988 & 3 & Binary & Amedee Geothermal Venture (Oski Energy) & Barber Nichols & USA \\
\hline USA & Ormesa IH (Ormesa Complex) & 1988 & 8.8 & Binary & Ormat & Ormat & Israel \\
\hline USA & $\begin{array}{l}\text { Steamboat IA (Steamboat } \\
\text { Complex) }\end{array}$ & 1988 & 2 & Binary & Ormat & Ormat & Israel \\
\hline USA & Bear Canyon & 1988 & 24.4 & Dry Steam & Calpine & Mitsubishi & Japan \\
\hline USA & BLM Unit 1 & 1988 & 30 & Double Flash & Terra Gen & Fuji & Japan \\
\hline USA & BLM Unit 2 & 1988 & 30 & Double Flash & Terra Gen & Fuji & Japan \\
\hline USA & BLM Unit 3 & 1988 & 30 & Double Flash & Terra Gen & Fuji & Japan \\
\hline USA & Dixie Valley & 1988 & 60.5 & Double Flash & Terra Gen & Fuji & Japan \\
\hline USA & Steamboat Hills & 1988 & 14.6 & Single Flash & Ormat & ORMAT & Israel \\
\hline USA & West Ford Flat & 1988 & 38 & Dry Steam & Calpine & Mitsubishi & Japan \\
\hline Mexico & Los Azufres & 1988 & 50 & Single Flash & Comision Federal de Electricidad & General Electric & Japan \\
\hline New Zealand & Ohaaki & 1988 & 46 & Single Flash & Contact Energy & Mitsubishi & Japan \\
\hline Indonesia & Kamojang & 1987 & 55 & Dry Steam & PLN & Mitsubishi & Japan \\
\hline
\end{tabular}




\begin{tabular}{|c|c|c|c|c|c|c|c|}
\hline Country & Plant Name & Year & Capacity & Type & Project Developer/Owner/Operator & Turbine Manufacturer & $\begin{array}{l}\text { Manufacturing } \\
\text { Location }\end{array}$ \\
\hline Indonesia & Kamojang & 1987 & 55 & Dry Steam & PLN & Mitsubishi & Japan \\
\hline Italy & Pianacce & 1987 & 20 & Dry Steam & Enel Green Power & Ansaldo/Tosi & Italy \\
\hline USA & Soda Lake 1 & 1987 & 5.1 & Binary & Cyrq Energy & Ormat & Israel \\
\hline USA & Wabuska II & 1987 & 1.6 & Binary & Home Stretch Geothermal & Ormat & Israel \\
\hline USA & Navy I & 1987 & 102.4 & Double Flash & Terra Gen & Fuji & Japan \\
\hline USA & Ormesa II (Ormesa Complex) & 1987 & 24 & Double Flash & Ormat & Mitsubishi & Japan \\
\hline Mexico & Cerro Prieto 2 & 1987 & 110 & Double Flash & Comision Federal de Electricidad & Toshiba & Japan \\
\hline China & Yangbajian North Unit-5 & 1986 & 3.18 & Double Flash & Electric Power Tibet & Fuji & Japan \\
\hline USA & Steamboat I & 1986 & 2.4 & Binary & Ormat & Ormat & Israel \\
\hline USA & Vulcan & 1986 & 40 & Double Flash & CalEnergy Generation & Mitsubishi & Japan \\
\hline Mexico & Cerro Prieto 2 & 1986 & 110 & Double Flash & Comision Federal de Electricidad & Toshiba & Japan \\
\hline Mexico & Cerro Prieto 3 & 1986 & 110 & Double Flash & Comision Federal de Electricidad & Toshiba & Japan \\
\hline Mexico & Cerro Prieto 3 & 1986 & 110 & Double Flash & Comision Federal de Electricidad & Toshiba & Japan \\
\hline Mexico & Los Azufres & 1986 & 5 & Back Pressure & Comision Federal de Electricidad & Toshiba & Japan \\
\hline Kenya & Olkaria I & 1985 & 15 & Single Flash & KenGen & Mitsubishi & Japan \\
\hline China & Yangbajian South Unit-3 & 1985 & 3 & Double Flash & Electric Power Tibet & Qingdao Jieneng & China \\
\hline USA & Wineagle & 1985 & 0.7 & Binary & Wineagle Development & Barber Nichols & USA \\
\hline USA & Beowawe & 1985 & 17 & Double Flash & Terra Gen & Mitsubishi & Japan \\
\hline USA & Bottle Rock & 1985 & 55 & Dry Steam & AltaRock Energy Inc & Fuji & Japan \\
\hline
\end{tabular}




\begin{tabular}{|c|c|c|c|c|c|c|c|}
\hline Country & Plant Name & Year & Capacity & Type & Project Developer/Owner/Operator & Turbine Manufacturer & $\begin{array}{l}\text { Manufacturing } \\
\text { Location }\end{array}$ \\
\hline USA & Grant & 1985 & 118 & Dry Steam & Calpine & Toshiba & Japan \\
\hline USA & Heber I (Heber Complex) & 1985 & 52 & Double Flash & Ormat & Mitsubishi & Japan \\
\hline USA & NCPA II & 1985 & 110 & Dry Steam & Northern California Power Agency & Toshiba & Japan \\
\hline USA & Quicksilver & 1985 & 118 & Dry Steam & Calpine & Toshiba & Japan \\
\hline Turkey & Kizildere-1 & 1984 & 15 & Double Flash & ZORLU & Ansaldo/Tosi & Italy \\
\hline USA & Wabuska I & 1984 & 1.6 & Binary & Home Stretch Geothermal & Ormat & Israel \\
\hline USA & Blundell 1 & 1984 & 26.1 & Single Flash & Pacific Corporation & General Electric & USA \\
\hline USA & Calistoga & 1984 & 110 & Dry Steam & Calpine & Toshiba & Japan \\
\hline Philippines & Mak-Ban C & 1984 & 55 & Single Flash & Aboitiz Power Corp & Mitsubishi & Japan \\
\hline Philippines & Mak-Ban C & 1984 & 55 & Single Flash & Aboitiz Power Corp & Mitsubishi & Japan \\
\hline USA & NCPA I No. 2 & 1983 & 110 & Dry Steam & Northern California Power Agency & Fuji & Japan \\
\hline USA & Socrates & 1983 & 118 & Dry Steam & Calpine & Toshiba & Japan \\
\hline USA & Sonoma & 1983 & 78 & Dry Steam & Calpine & Mitsubishi & Japan \\
\hline Indonesia & Kamojang & 1983 & 30 & Dry Steam & PLN & Mitsubishi & Japan \\
\hline Japan & Kirishima International & 1983 & 0.1 & Single Flash & Kirishima International & Fuji & Japan \\
\hline Philippines & Palimpinon I Unit 1 & 1983 & 37.5 & Single Flash & National Power Corporation & Fuji & Japan \\
\hline Philippines & Palimpinon I Unit 2 & 1983 & 37.5 & Single Flash & National Power Corporation & Fuji & Japan \\
\hline Philippines & Palimpinon I Unit 3 & 1983 & 37.5 & Single Flash & National Power Corporation & Fuji & Japan \\
\hline Philippines & Tongonan 1 & 1983 & 37.5 & Double Flash & $\begin{array}{l}\text { Unified Leyte Geothermal Energy, Inc. (ULGEI) (turned } \\
\text { over from PSALM) }\end{array}$ & Mitsubishi & Japan \\
\hline
\end{tabular}




\begin{tabular}{|c|c|c|c|c|c|c|c|}
\hline Country & Plant Name & Year & Capacity & Type & Project Developer/Owner/Operator & Turbine Manufacturer & $\begin{array}{l}\text { Manufacturing } \\
\text { Location }\end{array}$ \\
\hline Philippines & Tongonan 1 & 1983 & 37.5 & Double Flash & $\begin{array}{l}\text { Trans-Asia Oil and Energy Development Corp. (turned } \\
\text { over from PSALM) }\end{array}$ & Mitsubishi & Japan \\
\hline Philippines & Tongonan 1 & 1983 & 37.5 & Double Flash & Aboitiz Energy Solutions (turned over from PSALM) & Mitsubishi & Japan \\
\hline USA & Lake View & 1982 & 118 & Dry Steam & Calpine & Toshiba & Japan \\
\hline USA & Salton Sea I & 1982 & 10 & Single Flash & CalEnergy Generation & Fuji & Japan \\
\hline Kenya & Olkaria I & 1982 & 15 & Single Flash & KenGen & Mitsubishi & Japan \\
\hline China & Yangbajian South Unit-2 & 1982 & 3 & Double Flash & Electric Power Tibet & Qingdao Jieneng & China \\
\hline Japan & Mori & 1982 & 25 & Double Flash & Hokkaido Electric Power & Toshiba & Japan \\
\hline Mexico & Cerro Prieto 1 & 1982 & 30 & Double Flash & Comision Federal de Electricidad & Mitsubishi & Japan \\
\hline Mexico & Los Azufres & 1982 & 5 & Back Pressure & Comision Federal de Electricidad & Mitsubishi & Japan \\
\hline Mexico & Los Azufres & 1982 & 5 & Back Pressure & Comision Federal de Electricidad & Mitsubishi & Japan \\
\hline Mexico & Los Azufres & 1982 & 5 & Back Pressure & Comision Federal de Electricidad & Mitsubishi & Japan \\
\hline Mexico & Los Azufres & 1982 & 5 & Back Pressure & Comision Federal de Electricidad & Mitsubishi & Japan \\
\hline Philippines & Tiwi C & 1982 & 57 & Single Flash & AP Renewables Inc & Toshiba & Japan \\
\hline Philippines & Tiwi C & 1982 & 57 & Single Flash & AP Renewables Inc & Toshiba & Japan \\
\hline Kenya & Olkaria I & 1981 & 15 & Single Flash & KenGen & Mitsubishi & Japan \\
\hline China & Yangbajian South Unit-1 & 1981 & 3 & Double Flash & Electric Power Tibet & Qingdao Jieneng & China \\
\hline El Salvador & Ahuachapan No. 3 & 1981 & 35 & Double Flash & LaGeo & Fuji & Japan \\
\hline Iceland & Svartsengi BP & 1981 & 6 & Single Flash & Hitaveita Sudurnesja \& HS Orka & Fuji & Japan \\
\hline USA & Sulfur Springs & 1980 & 113 & Dry Steam & Calpine & Toshiba & Japan \\
\hline
\end{tabular}




\begin{tabular}{|c|c|c|c|c|c|c|c|}
\hline Country & Plant Name & Year & Capacity & Type & Project Developer/Owner/Operator & Turbine Manufacturer & $\begin{array}{l}\text { Manufacturing } \\
\text { Location }\end{array}$ \\
\hline USA & Big Geyser & 1980 & 97 & Dry Steam & Calpine & General Electric & USA \\
\hline Philippines & Mak-Ban B & 1980 & 63.2 & Double Flash & Aboitiz Power Corp & Mitsubishi & Japan \\
\hline Philippines & Mak-Ban B & 1980 & 63.2 & Double Flash & Aboitiz Power Corp & Mitsubishi & Japan \\
\hline Russia & Pauzhetskaya & 1980 & 11 & Single Flash & SC Geotherm & Kaluga Turbine & Russia \\
\hline USA & Cobb Creak & 1979 & 110 & Dry Steam & Calpine & Toshiba & Japan \\
\hline Mexico & Cerro Prieto 1 & 1979 & 37.5 & Single Flash & Comision Federal de Electricidad & Toshiba & Japan \\
\hline Mexico & Cerro Prieto 1 & 1979 & 37.5 & Single Flash & Comision Federal de Electricidad & Toshiba & Japan \\
\hline Philippines & Mak-Ban A & 1979 & 63.2 & Double Flash & Aboitiz Power Corp & Mitsubishi & Japan \\
\hline Philippines & Mak-Ban A & 1979 & 63.2 & Double Flash & Aboitiz Power Corp & Mitsubishi & Japan \\
\hline Philippines & Tiwi A & 1979 & 60 & Single Flash & AP Renewables Inc & Toshiba & Japan \\
\hline Philippines & Tiwi A & 1979 & 60 & Single Flash & AP Renewables Inc & Toshiba & Japan \\
\hline Iceland & Krafla & 1978 & 30 & Double Flash & Landsvirkjun & Mitsubishi & Japan \\
\hline Japan & Kakkonda & 1978 & 50 & Single Flash & Tohoku Electric Power & Toshiba & Japan \\
\hline Japan & Hatchobaru & 1977 & 55 & Double Flash & Kyushu Electric Power & Mitsubishi & Japan \\
\hline El Salvador & Ahuachapan No. 2 & 1976 & 30 & Single Flash & LaGeo & Mitsubishi & Japan \\
\hline USA & Eagle Rock & 1975 & 110 & Dry Steam & Calpine & Toshiba & Japan \\
\hline El Salvador & Ahuachapan No. 1 & 1975 & 30 & Single Flash & LaGeo & Mitsubishi & Japan \\
\hline Japan & Onikobe & 1975 & 15 & Single Flash & J-Power & Kawasaki & Japan \\
\hline Japan & Onuma & 1974 & 9.5 & Single Flash & Mitsubishi Material & Mitsubishi & Japan \\
\hline
\end{tabular}




\begin{tabular}{|c|c|c|c|c|c|c|c|}
\hline Country & Plant Name & Year & Capacity & Type & Project Developer/Owner/Operator & Turbine Manufacturer & $\begin{array}{l}\text { Manufacturing } \\
\text { Location }\end{array}$ \\
\hline Mexico & Cerro Prieto 1 & 1973 & 37.5 & Single Flash & Comision Federal de Electricidad & Toshiba & Japan \\
\hline Mexico & Cerro Prieto 1 & 1973 & 37.5 & Single Flash & Comision Federal de Electricidad & Toshiba & Japan \\
\hline USA & Ridgeline & 1972 & 110 & Dry Steam & Calpine & Toshiba & Japan \\
\hline USA & McCabe & 1971 & 110 & Dry Steam & Calpine & Toshiba & Japan \\
\hline Iceland & Bjarnarflag & 1969 & 3 & Single Flash & & Mitsubishi & Japan \\
\hline Japan & Otake & 1967 & 12.5 & Single Flash & Kyushu Electric Power & Mitsubishi & Japan \\
\hline Japan & Matsukawa & 1966 & 23.5 & Dry Steam & Tohoku Hydropower and Geothermal Energy & Toshiba & Japan \\
\hline Russia & Pauzhetskaya & 1966 & 5 & Single Flash & SC Geotherm & Kaluga Turbine & Russia \\
\hline New Zealand & Wairakei & 1958 & 117 & Single Flash & Contact Energy & General Electric & USA \\
\hline
\end{tabular}




\section{NOTICE}

This work was authored by the National Renewable Energy Laboratory, operated by Alliance for Sustainable Energy, LLC, for the U.S. Department of Energy (DOE) under Contract No. DE-AC3608G028308. Funding provided by the U.S. Department of Energy Office of Energy Efficiency and Renewable Energy Geothermal Technologies Office. The views expressed herein do not necessarily represent the views of the DOE or the U.S. Government.

This report is available at no cost from the National

Renewable Energy Laboratory (NREL) at www.nrel.gov/publications.

U.S. Department of Energy (DOE) reports produced after 1991 and a growing number of pre-1991 documents are available free via www.OSTI.gov.

Cover Photos: (left to right) iStock 2225189; iStock 16687273; Oak Ridge National Laboratory; iStock 24304597; iStock 26005993; iStock 2069560

NREL prints on paper that contains recycled content. 